University of Nebraska - Lincoln

DigitalCommons@University of Nebraska - Lincoln

2006

Sulfur Isotope Geochemistry of Sulfide Minerals

Robert R. Seal II

U.S. Geological Survey, 954 National Center, Reston, Virginia 20192, USA, rseal@usgs.gov

Follow this and additional works at: https://digitalcommons.unl.edu/usgsstaffpub

Part of the Earth Sciences Commons

Seal, Robert R. II, "Sulfur Isotope Geochemistry of Sulfide Minerals" (2006). USGS Staff -- Published Research. 345.

https://digitalcommons.unl.edu/usgsstaffpub/345

This Article is brought to you for free and open access by the US Geological Survey at DigitalCommons@University of Nebraska - Lincoln. It has been accepted for inclusion in USGS Staff -- Published Research by an authorized administrator of DigitalCommons@University of Nebraska - Lincoln. 


\title{
Sulfur Isotope Geochemistry of Sulfide Minerals
}

\author{
Robert R. Seal, II \\ U.S. Geological Survey \\ 954 National Center \\ Reston, Virginia, 20192, U.S.A. \\ e-mail: rseal@usgs.gov
}

\section{INTRODUCTION}

Sulfur, the $10^{\text {th }}$ most abundant element in the universe and the $14^{\text {th }}$ most abundant element in the Earth's crust, is the defining element of sulfide minerals and provides insights into the origins of these minerals through its stable isotopes. The insights come from variations in the isotopic composition of sulfide minerals and related compounds such as sulfate minerals or aqueous sulfur species, caused by preferential partitioning of isotopes among sulfur-bearing phases, known as fractionation. These variations arise from differences in temperature, or more importantly, oxidation and reduction reactions acting upon the sulfur. The oxidation and reduction reactions can occur at high temperature, such as in igneous systems, at intermediate temperatures, such as in hydrothermal systems, and at low temperature during sedimentary diagenesis. At high temperatures, the reactions tend to occur under equilibrium conditions, whereas at low temperatures, disequilibrium is prevalent. In addition, upper atmospheric processes also lead to isotopic fractionations that locally appear in the geologic record.

Sulfur isotope geochemistry as a subdiscipline of the geological sciences began in the late 1940s and early 1950s with early publications by Thode et al. (1949) and Szabo et al. (1950) on natural variations of sulfur isotopes, and Macnamara and Thode (1950) on the isotopic composition of terrestrial and meteoritic sulfur. Sakai (1957) presented an early scientific summary of sulfur isotope geochemistry, with a particular emphasis on high-temperature processes. Thode et al. (1961) also presented an early summary, but with an emphasis on lowtemperature processes. Both of these summaries outlined salient aspects of the global sulfur cycle. Sulfur isotope geochemistry understandably has had a long history of application to the study of sulfide-bearing mineral deposits. Early noteworthy papers include those by Kulp et al. (1956) and Jensen (1957, 1959). Similarly, there is also a legacy of contributions to understanding sedimentary diagenesis and the origin of diagenetic pyrite. The paper by Thode et al. (1951) represents one of the earliest efforts investigating sulfur isotope fractionations associated with bacterial sulfate reduction. Subsequent advances in the field of sulfur isotope geochemistry have been motivated by applications to an increasing variety of geochemical systems and by technological advances in analytical techniques. Noteworthy reviews related to the sulfur isotope geochemistry of sulfide minerals include those of Jensen (1967), Ohmoto and Rye (1979), and Ohmoto and Goldhaber (1997), all of which emphasize mineral deposits, Seal et al. (2000a) which emphasized sulfate minerals and their interactions with sulfides, and Canfield (2001) which emphasized biogeochemical aspects of sulfur isotopes.

A considerable body of knowledge exists on the metal stable isotopic composition of sulfide minerals - a topic that will not be covered in this paper. Recent analytical advances in plasma-source mass spectrometry have enabled precise isotopic measurements of numerous other metals in sulfide minerals including Fe (Johnson et al. 2003; Beard and Johnson 2004), Cu (Maréchal et al. 1999; Zhu et al. 2000; Larson et al. 2003; Albarède 2004), Zn (Maréchal et al. 1999; Albarède 2004) and Mo (Barling et al. 2001; Anbar 2004), among others. 
The intent of this chapter is to build upon previous reviews of sulfur isotope geochemistry as they relate to sulfide minerals, summarize landmark studies in the field, resolve, or at least discuss, existing controversies and summarize recent advances for a variety of geochemical settings. The first part of this chapter is designed to provide the reader with a basic understanding of the principles that form the foundations of stable isotope geochemistry. Next, an overview of analytical methods used to determine the isotope composition of sulfide minerals is presented. This overview is followed by a discussion of geochemical processes that determine the isotope characteristics of sulfide minerals and related compounds. The chapter then concludes with an examination of the stable isotope geochemistry of sulfide minerals in a variety of geochemical environments.

\section{FUNDAMENTAL ASPECTS OF SULFUR ISOTOPE GEOCHEMISTRY}

An isotope of an element is defined by the total number of protons $(Z)$ and neutrons $(N)$ present, which sum together to give the atomic mass (A). For example, the element sulfur is defined by the presence of 16 protons, but can have either 16, 17, 18, 19, or 20 neutrons, giving atomic masses of 32, 33, 34, 35, and $36 \mathrm{amu}$, respectively. These isotopes are written ${ }^{2}{ }^{32} \mathrm{~S}$, ${ }^{33} \mathrm{~S},{ }^{34} \mathrm{~S},{ }^{35} \mathrm{~S}$, and ${ }^{36} \mathrm{~S}$. Four of the five naturally occurring sulfur isotopes are stable ${ }^{32} \mathrm{~S},{ }^{33} \mathrm{~S}$, ${ }^{34} \mathrm{~S}$, and $\left.{ }^{36} \mathrm{~S}\right)$ and one $\left({ }^{35} \mathrm{~S}\right)$ is unstable, or radiogenic. The isotope ${ }^{35} \mathrm{~S}$ is formed from cosmic ray spallation of ${ }^{40} \mathrm{Ar}$ in the atmosphere (Peters 1959). It undergoes beta decay with a half-life of 87 days; therefore, it is not important from the perspective of naturally occurring sulfide minerals. The four stable isotopes of sulfur, ${ }^{32} \mathrm{~S},{ }^{33} \mathrm{~S},{ }^{34} \mathrm{~S}$, and ${ }^{36} \mathrm{~S}$, have approximate terrestrial abundances of 95.02, 0.75, 4.21, and 0.02\%, respectively (Macnamara and Thode 1950).

Stable isotope geochemistry is concerned primarily with the relative partitioning of stable isotopes among substances (i.e., changes in the ratios of isotopes), rather than their absolute abundances. The difference in the partitioning behavior of various isotopes, otherwise known as fractionation, is due to equilibrium and kinetic effects. In general, heavier isotopes form more stable bonds; molecules of different masses react at different rates (O'Neil 1986). Isotope ratios are usually expressed as the ratio of a minor isotope of an element to a major isotope of the element. For sulfide minerals, the principal ratio of concern is ${ }^{34} \mathrm{~S} /{ }^{32} \mathrm{~S}$. However, renewed interest in ${ }^{33} \mathrm{~S} /{ }^{32} \mathrm{~S}$ and ${ }^{36} \mathrm{~S} /{ }^{32} \mathrm{~S}$ ratios has been generated by the discovery of unexpected variations of these minor isotopes in Precambrian sulfide and sulfate minerals and in Martian meteorites (Farquhar et al. 2000a,b; Farquhar and Wing 2003). Most fractionation processes will typically cause variations in these ratios in the fifth or sixth decimal places. Because we are concerned with variations in isotopic ratios that are relatively small, the isotopic composition of substances is expressed in delta $(\delta)$ notation, as parts per thousand variation relative to a reference material. The $\delta$-notation for the ${ }^{34} \mathrm{~S} /{ }^{32} \mathrm{~S}$ composition of a substance is defined as:

$$
\delta^{34} \mathrm{~S}=\left(\frac{\left({ }^{34} \mathrm{~S} /{ }^{32} \mathrm{~S}\right)_{\text {sample }}-\left({ }^{34} \mathrm{~S} /{ }^{32} \mathrm{~S}\right)_{\text {reference }}}{\left({ }^{34} \mathrm{~S} /{ }^{32} \mathrm{~S}\right)_{\text {reference }}}\right) \times 1000
$$

which has units of parts per thousand or permil (\%o), also found in the literature spelled "per mil," "per mill," and "per mille." The values for $\delta^{33} \mathrm{~S}$ and $\delta^{36} \mathrm{~S}$ are similarly defined for the ratio of ${ }^{33} \mathrm{~S} /{ }^{32} \mathrm{~S}$ and ${ }^{36} \mathrm{~S} /{ }^{32} \mathrm{~S}$, respectively. The agreed upon reference for sulfur isotopes is Vienna Canyon Diablo Troilite (VCDT) with $\delta^{34} \mathrm{~S}=0.0 \%$ o by definition, which is currently defined relative to a silver sulfide reference material IAEA-S-1 with an assigned value of $-0.3 \%$ o because the supply of the Canyon Diablo Troilite reference material has been exhausted (Krouse and Coplen 1997). The reference was originally defined by the isotopic composition of troilite (FeS) from the Canyon Diablo iron meteorite. The absolute ${ }^{34} \mathrm{~S} /{ }^{32} \mathrm{~S}$ ratio for Canyon 
Diablo Troilite is $4.50045 \times 10^{-3}$ (Ault and Jensen 1963). The selection of a meteoritic sulfide mineral as the reference for sulfur is useful because meteoritic sulfide is thought to represent the primordial sulfur isotopic composition of Earth (Nielsen et al. 1991). Thus, any variations in the isotopic composition of terrestrial sulfur relative to VCDT reflects differentiation since the formation of Earth.

For sulfur, which has more than two stable isotopes, ${ }^{34} \mathrm{~S} /{ }^{32} \mathrm{~S}$ is the ratio most commonly measured in studies of terrestrial systems. This ratio was chosen for two main reasons. Firstly, it represents the most abundant isotopes of these elements, which facilitates analysis. Secondly, isotopic fractionation is governed by mass balance such that different isotopic ratios tend to vary systematically with one another in proportions that can be approximated by the mass differences among the isotopes. In other words, the variations in the ${ }^{33} \mathrm{~S} /{ }^{32} \mathrm{~S}$ ratio of a sample will be approximately half that of the ${ }^{34} \mathrm{~S} /{ }^{32} \mathrm{~S}$ ratio because of the relative differences in masses. Likewise, the variations in the ${ }^{36} \mathrm{~S} /{ }^{32} \mathrm{~S}$ ratio of a sample will be approximately twice that of the ${ }^{34} \mathrm{~S} /{ }^{32} \mathrm{~S}$ ratio. This linear fractionation trend due to physical and chemical processes is known "mass-dependent fractionation" (Urey 1947; Hulston and Thode 1965a,b), which is in distinct contrast to "mass-independent fractionation." Mass-independent fractionation is reflected by non-linear variations in isotopic fractionation with mass, and will be discussed in more detail below.

Fractionation can be considered in terms of isotopic exchange reactions, which are driven thermodynamically toward equilibrium. Thus, isotopic equilibrium, for example between sphalerite $(\mathrm{Sl})$ and galena $(\mathrm{Gn})$, can be described by an isotopic exchange reaction such as:

$$
\mathrm{Pb}^{34} \mathrm{~S}+\mathrm{Zn}^{32} \mathrm{~S}=\mathrm{Pb}^{32} \mathrm{~S}+\mathrm{Zn}^{34} \mathrm{~S}
$$

which is written in a form with one exchangeable atom of sulfur. The equilibrium constant $(K)$ for this reaction is equivalent to the isotopic fractionation factor $(\alpha)$ :

$$
K=\frac{\mathrm{Pb}^{32} \mathrm{~S} \cdot \mathrm{Zn}^{34} \mathrm{~S}}{\mathrm{~Pb}^{34} \mathrm{~S} \cdot \mathrm{Zn}^{32} \mathrm{~S}}=\frac{\left({ }^{34} \mathrm{~S} /{ }^{32} \mathrm{~S}\right)_{\mathrm{S} 1}}{\left({ }^{34} \mathrm{~S} /{ }^{32} \mathrm{~S}\right)_{\mathrm{Gn}}}=\alpha_{\mathrm{Sl}-\mathrm{Gn}}
$$

where the isotopic species are meant to represent their respective chemical activities. Thus, in a more general form, the partitioning of stable isotopes between two substances, $A$ and $B$, is quantitatively described by a fractionation factor, which is defined as:

$$
\alpha_{A-B}=\frac{R_{A}}{R_{B}}
$$

where $R$ is ${ }^{34} \mathrm{~S} /{ }^{32} \mathrm{~S}$. This equation can be recast in terms of $\delta$ values using Equation (1) as:

$$
\alpha_{A-B}=\frac{1+\frac{\delta_{A}}{1000}}{1+\frac{\delta_{B}}{1000}}=\frac{1000+\delta_{A}}{1000+\delta_{B}}
$$

Values of $\alpha$ are typically near unity, with variations normally in the third decimal place $(1.00 \mathrm{X})$. For example, the equilibrium ${ }^{34} \mathrm{~S} /{ }^{32} \mathrm{~S}$ fractionation between sphalerite and galena at $300{ }^{\circ} \mathrm{C}$ has been measured to have an $\alpha_{\mathrm{SI}-\mathrm{Gn}}$ value of 1.0022 . Thus, sphalerite is enriched in ${ }^{34} \mathrm{~S}$ relative to galena by $2.2 \%$ (i.e., the fractionation equals $2.2 \%$ ). For an $\alpha$ value less than unity, such as $\alpha_{\mathrm{Gn}-\mathrm{Sl}}$, which equals 0.9978 , the galena is depleted in ${ }^{34} \mathrm{~S}$ relative to sphalerite by $2.2 \%$ o (i.e., the fractionation equals $-2.2 \%$ ). In the literature, fractionation factors may be expressed in a variety of ways including $\alpha, 1000 \ln \alpha$, and $\Delta$, among others. The value $\Delta_{A-B}$ is defined as:

$$
\Delta_{A-B}=\delta_{A}-\delta_{B}
$$


A convenient mathematical relationship is that $1000 \ln (1.00 \mathrm{X})$ is approximately equal to $\mathrm{X}$, so that:

$$
\Delta_{A-B} \approx 1000 \ln \alpha_{A-B}
$$

Isotopic fractionations may also be defined in terms of an enrichment factor $(\varepsilon)$, where:

$$
\varepsilon_{A-B}=\left(\alpha_{A-B}-1\right) \times 1000
$$

\section{ANALYTICAL METHODS}

Several procedures are available to determine the sulfur isotopic compositions of sulfide minerals. Conventional analyses typically involve mineral separation procedures that may include handpicking or gravimetric techniques (heavy liquids, panning, etc.) or wet chemical techniques. Once a suitable concentration of the desired compound is obtained, the sulfur is extracted and converted to a gaseous form that is amenable to mass spectrometric analysis. For sulfur, the gas is $\mathrm{SO}_{2}$. Alternatively, the gas $\mathrm{SF}_{6}$ may be used, which has the advantages of being an inert, non-absorbing gas, and lacking ambiguity in isotopic speciation because fluorine has only one stable isotope. It has the disadvantage of requiring potential hazardous fluorinating reagents. The amount of sample required varies among laboratories, but typically ranges from 5 to $20 \mathrm{mg}$ of pure mineral separate for $\delta^{34} \mathrm{~S}$ using conventional techniques. Typical analytical uncertainties $(1 \sigma)$ for conventional techniques are $\pm 0.1 \%$ for $\delta^{34} \mathrm{~S}$.

For conventional $\delta^{34} \mathrm{~S}$ analysis of sulfide minerals, $\mathrm{SO}_{2}$ is produced for analysis by reacting the sulfate mineral with an oxidant $\left(\mathrm{CuO}, \mathrm{Cu}_{2} \mathrm{O}\right.$, or $\left.\mathrm{V}_{2} \mathrm{O}_{5}\right)$ at elevated temperatures (1000 to $1200{ }^{\circ} \mathrm{C}$ ) under vacuum (Holt and Engelkemeier 1970; Haur et al. 1973; Coleman and Moore 1978). $\mathrm{SF}_{6}$ can be prepared using $\mathrm{BrF}_{3}, \mathrm{BrF}_{5}$, or elemental $\mathrm{F}$ as reagents at elevated temperatures $\left(300{ }^{\circ} \mathrm{C}\right)$ in nickel reaction vessels; the $\mathrm{SF}_{6}$ is then purified cryogenically and through gas chromatography (Hulston and Thode 1965a; Puchelt et al. 1971; Thode and Rees 1971). Other conventional techniques for the $\delta^{34} S$ analysis of sulfide minerals have been summarized by Rees and Holt (1991).

Isotopic analysis is done on a gas-source, sector-type, isotope ratio mass spectrometer. In gas-source mass spectrometers, $\mathrm{SO}_{2}$ gas molecules are ionized to positively charged particles, such as $\mathrm{SO}_{2}{ }^{+}$, which are accelerated through a voltage gradient. The ion beam passes through a magnetic field, which causes separation of various masses such as $64\left({ }^{32} \mathrm{~S}^{16} \mathrm{O}_{2}\right)$ and 66 $\left({ }^{34} \mathrm{~S}^{16} \mathrm{O}_{2},{ }^{34} \mathrm{~S}^{18} \mathrm{O}^{16} \mathrm{O}\right)$. In conventional dual-inlet mass spectrometers, a sample gas is measured alternately with a reference gas. The beam currents are measured in faraday cups and can be related to the isotopic ratio when the sample and standard gases are compared.

Technological advances over the past decade have opened new frontiers in stable isotope analysis of sulfide minerals. One new area is the in situ microanalysis of minerals. For in situ analysis, a growing body of sulfur isotope data has been generated from samples of sulfide minerals using the secondary ion mass spectrometer (SIMS) otherwise known as the ion microprobe (Eldridge et al. 1988; Paterson et al. 1997; McKibben and Riciputi 1998). The ion microprobe bombards a sample with a beam of charged Cs or O. The ion beam causes the sample to be ablated as secondary ionic species, which are measured in a mass spectrometer. Spatial resolution less than $20 \mu \mathrm{m}$ can be achieved with an analytical uncertainty of $\pm 0.25 \%$ o for sulfur isotope analyses using the ion microprobe (Paterson et al. 1997).

Techniques for in situ analysis have also been developed using lasers as heat sources to drive reactions producing either $\mathrm{SO}_{2}$ or $\mathrm{SF}_{6}$ for isotopic analysis, and have been reviewed by Shanks et al. (1998). Laser-based techniques resulting in $\mathrm{SO}_{2}$ for isotopic analysis were first developed by Crowe et al. (1990). Spatial resolution can be achieved as good as a spot size of $150 \mu \mathrm{m}$ having an analytical precision of \pm 0.3 to $0.6 \%$ o. Early development of laser- 
based sulfur isotope analysis on $\mathrm{SF}_{6}$ was by Rumble et al. (1993) and Beaudoin and Taylor (1994). Spatial resolution $(<150 \mu \mathrm{m})$ and analytical precision $( \pm 0.2 \%$ o for in situ analysis are routinely similar to those achieved for the analysis of $\mathrm{SO}_{2}$.

Another recent advance is the development of continuous-flow techniques that use a combination of an elemental analyzer and gas chromatograph for online combustion and purification of gases that are then carried in a He stream directly into the ion source of a mass spectrometer, which allows for the mass production of data from small samples. Continuous-flow systems can measure the sulfur isotopic ratios of sulfide samples in the microgram range, compared to the milligram range for conventional techniques (Giesemann et al. 1994). Sample gases are prepared by on-line peripheral devices such as elemental analyzers that are capable of processing 50 to 100 samples per day in a highly automated fashion. Furthermore, most sulfur isotope measurements can be made without mineral purification, if bulk sulfur data are all that is desired.

\section{REFERENCE RESERVOIRS}

Sulfur isotope variations on Earth can be considered relative to geologically important reservoirs. The most common reference reservoirs for sulfur isotopes in terrestrial systems are meteoritic sulfur and seawater. Meteoritic sulfur, such as that in Canyon Diablo troilite, provides a convenient reference because it is generally regarded as approximating the bulk composition of the Earth. The iron meteorites have an average sulfur isotope composition of $\delta^{34} \mathrm{~S}=0.2 \pm 0.2 \%$ (Kaplan and Hulston 1966), which is indistinguishable from that of pristine mid-ocean ridge basalts $\left(\delta^{34} \mathrm{~S}=0.3 \pm 0.5 \%\right.$; Sakai et al. 1984). Geochemical processes, the most notable of which are oxidation and reduction, profoundly fractionate sulfur isotopes away from bulk-Earth values in geological systems (Fig. 1). Oxidation processes produce species that are enriched in ${ }^{34} \mathrm{~S}$ relative to the starting material, whereas reduction produces species that are depleted in ${ }^{34} \mathrm{~S}$.

Oxidation-reduction reactions involving reduced sulfur from the interior of the Earth throughout its history have resulted in a $\delta^{34} \mathrm{~S}$ of $21.0 \pm 0.2 \%$ o for dissolved sulfate in modern oceans (Rees et al. 1978). Because of the volume and importance of the ocean in the global sulfur cycle, this composition is another important reference reservoir from which to evaluate sulfur isotope variations in geological systems. The $\delta^{34} \mathrm{~S}$ of sulfate in ancient oceans as recorded by marine evaporite sequences (Claypool et al. 1980) has varied from a low near 0\%o during

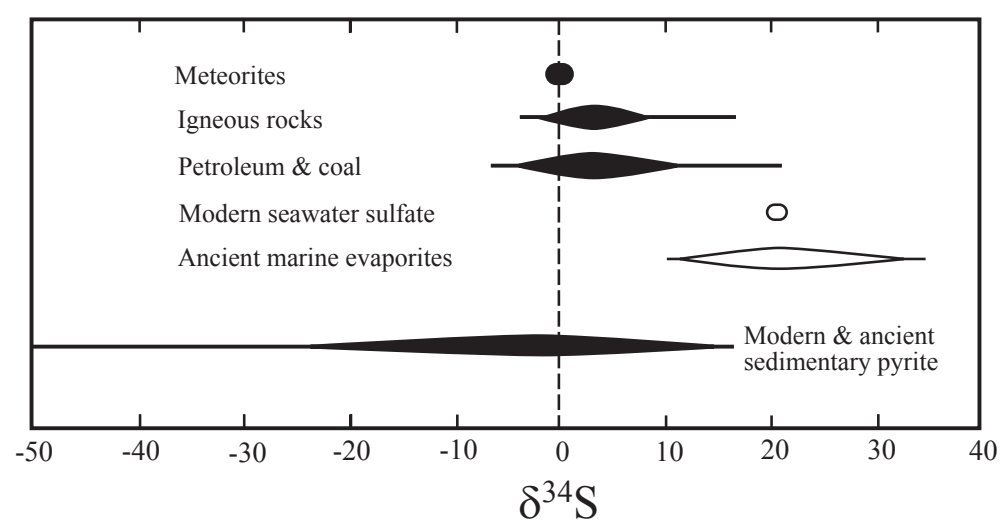

Figure 1. $\delta^{34} \mathrm{~S}$ of various geologic reservoirs. Modified from Seal et al. (2000a). All isotopic values in permil (VCDT). 
Archean time to a high of $35 \%$ during Cambrian time. The causes and implications of the secular variations in the sulfur isotope composition of seawater are discussed in a later section.

\section{FACTORS THAT CONTROL SULFUR ISOTOPE FRACTIONATION}

Most isotopic fractionation is the result of variations in thermodynamic properties of molecules that are dependent on mass. Details of the thermodynamic basis for understanding isotope fractionation have been presented by Urey (1947), Bigeleisen and Mayer (1947), and Bigeleisen (1952). Isotope fractionation may result from equilibrium or kinetically controlled chemical and physical processes. Equilibrium processes include isotopic exchange reactions, which redistribute isotopes among molecules of different substances. Equilibrium isotope effects result from the effect of atomic mass on bonding; molecules containing a heavier isotope are more stable than those containing a lighter isotope. Kinetic processes include irreversible chemical reactions, such as bacterially mediated processes like sulfate reduction and physical processes such as evaporation and diffusion (O’Neil 1986). Kinetic isotope effects are related to greater translational and vibrational velocities associated with lighter isotopes. It is easier to break bonds with lighter isotopes, for example the ${ }^{32} \mathrm{~S}-\mathrm{O}$ bond, compared with the ${ }^{34} \mathrm{~S}-\mathrm{O}$ bond, in processes such as bacterially mediated reduction of dissolved sulfate to sulfide.

Among the several factors that influence the magnitude of equilibrium stable isotope fractionations are temperature, chemical composition, crystal structure and pressure (O'Neil 1986). For the present discussion, temperature and chemical composition are the most important. Pressure effects are minimal at upper crustal conditions. The temperature dependence of fractionation factors results from the relative effect of temperature on the vibrational energies of two substances. Theoretical considerations indicate that the stable isotope fractionation between two substances should approach zero at infinite temperature (Bigeleisen and Mayer 1947). These fractionations are generally described well by equations of the form:

$$
1000 \ln \alpha=\frac{\mathrm{a}}{T^{2}}+\frac{\mathrm{b}}{T}+\mathrm{c}
$$

where $\mathrm{a}, \mathrm{b}$, and $\mathrm{c}$ are empirically determined constants.

The dependence of isotopic fractionation can be related to chemical variables such as oxidation state, ionic charge, atomic mass, and the electronic configuration of the isotopic elements and the elements to which they are bound (O'Neil 1986). For sulfur-bearing systems, the effect of the oxidation state of sulfur is especially important. The higher oxidation states of sulfur are enriched in the heavier isotopes relative to lower oxidation states such that ${ }^{34} \mathrm{~S}$ enrichment follows the general trend $\mathrm{SO}_{4}{ }^{2-}>\mathrm{SO}_{3}{ }^{2-}>\mathrm{S}_{x}{ }^{\circ}>\mathrm{S}^{2-}$ (Sakai 1968; Bachinski 1969). In the geological record, this trend is reflected by the fact that sulfate minerals typically have higher $\delta^{34} \mathrm{~S}$ values than cogenetic sulfide minerals in a variety of geochemical settings.

Cationic substitutions also play an important role in stable isotope fractionations. Heavier elements such as $\mathrm{Ba}$ or $\mathrm{Pb}$ form stronger bonds than lighter elements such as $\mathrm{Ca}$ or $\mathrm{Zn}$. Thus, on a relative basis, the heavier elements are able to bond more effectively with lighter, more energetic stable isotopes such as ${ }^{16} \mathrm{O}$ or ${ }^{32} \mathrm{~S}$. O'Neil et al. (1969) documented a cation-mass dependence of ${ }^{18} \mathrm{O}$ enrichment in divalent metal-carbonate minerals with ${ }^{18} \mathrm{O}$ enrichment following the order $\mathrm{CaCO}_{3}>\mathrm{SrCO}_{3}>\mathrm{BaCO}_{3}$. Likewise, the ${ }^{34} \mathrm{~S}$ enrichment in divalent sulfide minerals is such that $\mathrm{ZnS}>\mathrm{PbS}$.

\section{EQUILIBRIUM FRACTIONATION FACTORS}

Equilibrium isotopic fractionation factors are typically derived by one of three methods: 
(1) experimental determination, (2) theoretical estimation using calculated bond strengths or statistical mechanical calculations based on data on vibrational frequencies of compounds, or (3) analysis of natural samples for which independent estimates of temperature are available. Each method has advantages and disadvantages. Experimental determination provides a direct measurement of the fractionation, but such efforts are commonly hampered by experimental kinetic limitations and the fact that media used in experiments typically do not approximate natural conditions. Theoretical estimation avoids the kinetic problems of experimental studies, but is limited by the availability and accuracy of data required for the estimation. Fractionation factors derived from the analysis of natural materials provide a means of investigating isotopic fractionations when data from neither of the other methods are available. However, the accuracy of this method can be affected by retrograde isotopic exchange and uncertainties related to whether or not the mineral pairs are cogenetic and to the independent temperature estimate derived from fluid inclusions, for example.

\section{Experimentally determined fractionation factors}

Experimental sulfur isotopic fractionation factors for sulfide minerals are limited to a few mineral species, despite the geological importance of numerous sulfides, particularly to ore-forming systems. Ohmoto and Rye (1979) reviewed and critically evaluated the available experimental sulfur isotope fractionation data relative to $\mathrm{H}_{2} \mathrm{~S}$, which included temperaturedependent fractionation factors for sulfites, $\mathrm{SO}_{2}, \mathrm{H}_{2} \mathrm{~S}$ gas, $\mathrm{HS}^{-}, \mathrm{S}^{2-}$, and $\mathrm{S}$, and the minerals pyrite $\left(\mathrm{FeS}_{2}\right)$, sphalerite $(\mathrm{ZnS})$, pyrrhotite $\left(\mathrm{Fe}_{1-x} \mathrm{~S}\right)$, chalcopyrite $\left(\mathrm{CuFeS}_{2}\right)$, and galena $(\mathrm{PbS})$. Their evaluation and compilation included experimental studies by Grootenboer and Schwarz (1969), Schiller et al. (1969), Grinenko and Thode (1970), Kajiwara and Krouse (1971), Salomons (1971), Thode et al. (1971), Kiyosu (1973), Robinson (1973), and Czamanske and Rye (1974), and estimates following Sakai (1968) and Bachinski (1969). Ohmoto and Lasaga (1982) re-evaluated experimental studies investigating sulfur-isotope fractionations between aqueous sulfate and sulfide (Robinson 1973; Bahr 1976; Igumnov et al. 1977; Sakai and Dickson 1978) and presented a revised equation describing $\mathrm{SO}_{4}{ }^{2-}-\mathrm{H}_{2} \mathrm{~S}$ sulfur-isotope fractionation as a function of temperature. No further re-evaluation of these data is made in this chapter. Expressions describing the temperature-dependent sulfur isotope fractionation of these compounds relative to $\mathrm{H}_{2} \mathrm{~S}$ are summarized in Table 1 and Figure 2.

Several other experimental studies of sulfur-isotope fractionation have been published since the compilation of Ohmoto and Rye (1979). Szaran (1996) measured the sulfur isotope fractionation between dissolved and gaseous $\mathrm{H}_{2} \mathrm{~S}$ from 11 to $30^{\circ} \mathrm{C}$ and found that dissolved $\mathrm{H}_{2} \mathrm{~S}$ is minimally enriched in ${ }^{34} \mathrm{~S}$ relative to the gaseous $\mathrm{H}_{2} \mathrm{~S}$, ranging from $2.2 \%$ at $11{ }^{\circ} \mathrm{C}$ to $1.1 \%$ at $30^{\circ} \mathrm{C}$. In comparison, Ohmoto and Rye (1979) reported no fractionation, presumably for all temperatures. A least-squares fit to the data of Szaran (1996) is presented in Table 1.

Hubberten (1980) conducted synthesis experiments investigating sulfur isotope fractionations between 280 and $700{ }^{\circ} \mathrm{C}$ for galena, argentite $\left(\mathrm{Ag}_{2} \mathrm{~S}\right)$, covellite $(\mathrm{CuS})$ or digenite $\left(\mathrm{Cu}_{9} \mathrm{~S}_{5}\right)$ equilibrated with sulfur. Bente and Nielsen (1982) conducted reversed experiments between 150 and $600{ }^{\circ} \mathrm{C}$ on isotopic fractionations between bismuthinite $\left(\mathrm{Bi}_{2} \mathrm{~S}_{3}\right)$ and sulfur. Suvorova and Tenishev (1976) and Suvorova (1978) conducted synthesis experiments investigating sulfur isotope fractionation between 300 and $600{ }^{\circ} \mathrm{C}$ between various mineral pairs including sphalerite-molybdenite (Sl-Mb), galena-molybdenite ( $\mathrm{Gn}$ $\mathrm{Mb})$, galena-herzenbergite $(\mathrm{SnS})(\mathrm{Gn}-\mathrm{Hz})$, tungstenite $\left(\mathrm{WS}_{2}\right)$-molybdenite $(\mathrm{Tn}-\mathrm{Mb})$, and stibnite-molybdenite (St-Mb).

The accuracy of these more recent fractionation factors, especially those from the synthesis experiments, warrants evaluation. The rates of solid-state reactions among various sulfides minerals are known to vary by several orders of magnitude. Molybdenite is considered to be one of the most refractory and argentite to be one of the most reactive (Barton and 
Table 1. Equilibrium isotopic fractionation factors for sulfide minerals and related compounds described by the equation

$$
1000 \ln \alpha_{i-\mathrm{H}_{2} \mathrm{~S}}=\frac{\mathrm{a} \times 10^{6}}{T^{2}}+\frac{\mathrm{b} \times 10^{3}}{T}+\mathrm{c} ; \quad(T \text { in } \mathrm{K})
$$

\begin{tabular}{lccccc}
\hline \multicolumn{1}{c}{ Compound or component $(\boldsymbol{i})$} & $\mathbf{a}$ & $\mathbf{b}$ & $\mathbf{c}$ & $\begin{array}{c}\boldsymbol{T}\left({ }^{\circ} \mathbf{C}\right) \\
\text { range* }\end{array}$ & $\begin{array}{c}\text { Data } \\
\text { sources }\end{array}$ \\
\hline Sulfate minerals and aqueous sulfate & 6.463 & & 0.56 & $200-400$ & $(2)$ \\
$\mathrm{Sulfites}$ & 4.12 & 5.82 & -5.0 & $>25$ & $(1)$ \\
$\mathrm{SO}_{2}$ & 4.70 & & -0.5 & $350-1050$ & $(1)$ \\
$\mathrm{S}\left(=\mathrm{S}_{8}\right)$ & -0.16 & & & $200-400$ & $(1)$ \\
$\mathrm{H}_{2} \mathrm{~S}_{\text {aqueous-gaseous }}$ & 0.71 & & -6.67 & $11-30$ & $(3)$ \\
$\mathrm{HS}^{-}$ & -0.06 & & -0.6 & $50-350$ & $(1)$ \\
$\mathrm{S}^{2-}$ & -0.21 & -1.23 & -1.23 & $>25$ & $(1)$ \\
$\mathrm{FeS}_{2}$ & 0.40 & & & $200-700$ & $(1)$ \\
$\mathrm{FeS}$ & 0.10 & & & $200-600$ & $(1)$ \\
$\mathrm{CuFeS}$ & -0.05 & & & $200-600$ & $(1)$ \\
$\mathrm{PbS}^{\mathrm{ZnS}}$ & -0.63 & & & $50-700$ & $(1)$ \\
$\mathrm{Ag} \mathrm{S}_{2} \mathrm{~S}$ & 0.10 & & & $50-705$ & $(1)$ \\
$\mathrm{Cu} \mathrm{S}^{2}$ & -0.62 & & & $280-700$ & $(4)$ \\
$\mathrm{CuS}$ & -0.06 & & & $510-630$ & $(4)$ \\
$\mathrm{Bi}_{2} \mathrm{~S}_{3}$ & 0.04 & & & $280-490$ & $(4)$ \\
\hline
\end{tabular}

* Temperature range refers to the experimental temperature range; note that fractionation factors may extrapolate significantly beyond these ranges (see text).

Data sources: (1) Ohmoto and Rye 1979; (2) Ohmoto and Lasaga 1982; (3) Szaran 1996; (4) Hubberten 1980; (5) Bente and Nielsen 1982.

Skinner 1979). The methodologies and systems can be evaluated critically, in part through comparison with systems evaluated by Ohmoto and Rye (1979).

The experimental data of Hubberten (1980) for sulfur isotope fractionation between galena and sulfur $\left(280\right.$ to $700{ }^{\circ} \mathrm{C}$ ) can be evaluated by comparison with galena-sulfur fractionations derived by the combination of the galena- $\mathrm{H}_{2} \mathrm{~S}\left(50\right.$ to $\left.700{ }^{\circ} \mathrm{C}\right)$ and sulfur- $\mathrm{H}_{2} \mathrm{~S}$ (200 to $400{ }^{\circ} \mathrm{C}$ ) expressions from Ohmoto and Rye (1979). From 280 to $700{ }^{\circ} \mathrm{C}$, the two estimates of galena-sulfur isotope fractionation are identical within analytical uncertainty. No independent comparisons based on experimental results can be made for the argentite, digenite, and covellite data of Hubberten (1980), but the galena-sulfur comparison at least adds confidence to the experimental technique. Nevertheless, the fractionations for argentite, digenite, and covellite are consistent with those predicted following the methods of Sakai (1968) and Bachinski (1969) as summarized by Ohmoto and Rye (1979).

Likewise, no independent comparison of the results of Bente and Nielsen (1982) for bismuthinite-sulfur fractionations can be made, but their results are also consistent with theoretical predictions. Expressions for sulfur isotope fractionation of argentite, digenite, covellite, and bismuthinite with $\mathrm{H}_{2} \mathrm{~S}$, based on the experimental results of Hubberten (1980) and Bente and Nielsen (1982) combined with the sulfur- $\mathrm{H}_{2} \mathrm{~S}$ fractionations from Ohmoto and Rye (1979) are presented in Table 1.

The experimental results of Suvorova and Tenishev (1976) and Suvorova (1978) for sulfur isotope exchange between molybdenite and a variety of sulfide minerals, and between galena and herzenbergite, are problematic. Derived expressions for fractionation between sphalerite and galena are within $0.4 \%$ of expressions derived from Ohmoto and Rye (1979). However, fractionations for various sulfide minerals relative to $\mathrm{H}_{2} \mathrm{~S}$ derived on the basis of their results 


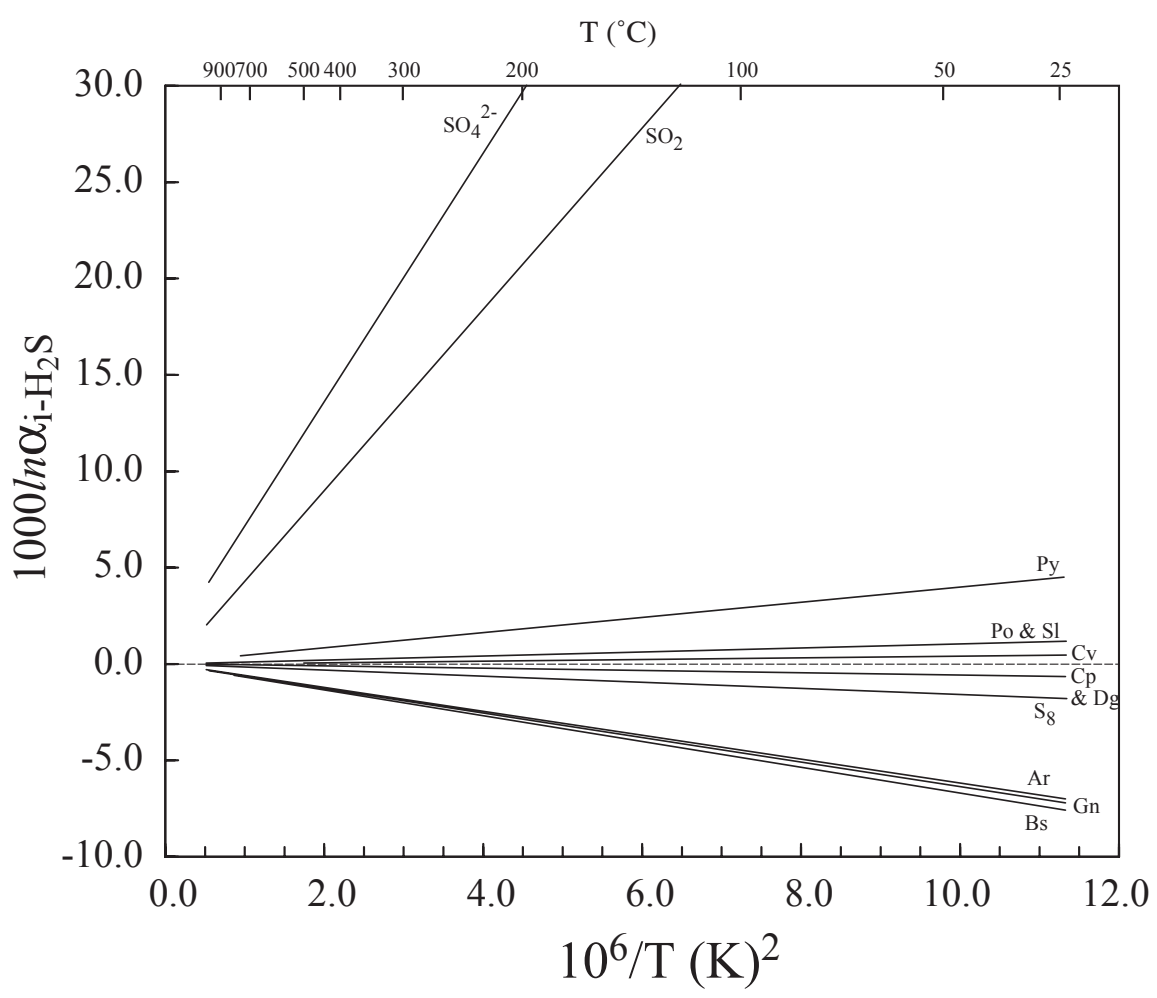

Figure 2. Temperature dependence of experimentally determined equilibrium sulfur isotope fractionation factors relative to $\mathrm{H}_{2} \mathrm{~S}$ for a variety of sulfur species and sulfide minerals. The dashed line indicates a 0.0\% 1000ln $\alpha$ value. Data from Table 1. Abbreviations: Ar argentite, Bs bismuthinite, $\mathrm{Cp}$ chalcopyrite, $\mathrm{Cv}$ covellite, Dg digenite, Gn galena, Po pyrrhotite, Py pyrite, Sl sphalerite.

are significantly different from those summarized by Ohmoto and Rye (1979), or those based on theoretical predictions. In fact, the fractionations appear to be the opposite of what would be expected. On the basis of the information provided by Suvorova and Tenishev (1976) and Suvorova (1978), it is unclear whether the discrepancy results from experimental or computational error. Therefore, the results of these studies are not included in Table 1 or Figure 2.

\section{Geothermometry}

The temperature-dependence of sulfur isotope fractionation between two phases, typically solids, forms the basis of sulfur isotope geothermometry. Sulfur isotope geothermometry is based on the partitioning of sulfur isotopes between two substances such as sphalerite and galena, or pyrite and barite. Sulfur isotope fractionation between dissolved $\mathrm{SO}_{4}{ }^{2-}$ and $\mathrm{H}_{2} \mathrm{~S}$ has been used to assess reservoir temperatures in geothermal systems. The use of sulfur isotopes for this type of geothermometry is based on several requirements or assumptions. Firstly, the minerals must have formed contemporaneously and in equilibrium with one another at a single temperature. Secondly, subsequent re-equilibration or alteration of one or both minerals must not have occurred. Thirdly, pure minerals must be separated for isotopic analysis. Fourthly, the temperature dependence of the fractionation factors must be known. In addition, greater precision in the temperature estimate will be achieved from the use of mineral pairs that have the greatest temperature dependence in their fractionations. Kinetic considerations offer both 
advantages and disadvantages to geothermometry. Rapid kinetics of isotope exchange promotes mineral formation under equilibrium conditions. Unfortunately, rapid exchange kinetics also makes mineral pairs prone to re-equilibration during cooling. In contrast, sluggish kinetics hampers isotopic equilibration between minerals. However, once equilibrated, mineral pairs with sluggish exchange kinetics will tend to record formation conditions without subsequent re-equilibration at lower temperatures.

Because of the relationships expressed in Equations (6) and (7), mineral-mineral fractionation equations can be derived from the equations in Table 1. An equation to calculate the temperature recorded by the coexisting pair of sphalerite $(\mathrm{Sl})$ and galena $(\mathrm{Gn})$ can be derived as follows:

$$
1000 \ln \alpha_{\mathrm{Sl}-\mathrm{Gn}} \approx \Delta_{\mathrm{Sl}-\mathrm{Gn}}=\delta^{34} \mathrm{~S}_{\mathrm{Sl}}-\delta^{34} \mathrm{~S}_{\mathrm{Gn}}
$$

Thus:

$$
\Delta_{\mathrm{Sl}-\mathrm{Gn}}=\Delta_{\mathrm{Sl}-\mathrm{H}_{2} \mathrm{~S}}-\Delta_{\mathrm{Gn}-\mathrm{H}_{2} \mathrm{~S}}=\delta^{34} \mathrm{~S}_{\mathrm{Sl}}-\delta^{34} \mathrm{~S}_{\mathrm{H}_{2} \mathrm{~S}}-\left(\delta^{34} \mathrm{~S}_{\mathrm{Gn}}-\delta^{34} \mathrm{~S}_{\mathrm{H}_{2} \mathrm{~S}}\right)
$$

or

$$
\Delta_{\mathrm{Sl-Gn}} \approx 1000 \ln \alpha_{\mathrm{Sl}_{-} \mathrm{H}_{2} \mathrm{~S}}-1000 \ln \alpha_{\mathrm{Gn}-\mathrm{H}_{2} \mathrm{~S}}
$$

Substituting from Table 1 gives:

$$
\Delta_{\mathrm{Sl-Gn}}=\left(\frac{0.10 \times 10^{6}}{T^{2}}\right)-\left(\frac{-0.63 \times 10^{6}}{T^{2}}\right)
$$

with $T$ in $\mathrm{K}$, or:

$$
\Delta_{\mathrm{Sl-Gn}}=\frac{0.73 \times 10^{6}}{T^{2}}
$$

Solving for $T$, and converting to ${ }^{\circ} \mathrm{C}$ yields:

$$
T\left({ }^{\circ} \mathrm{C}\right)=\sqrt{\frac{0.73 \times 10^{6}}{\Delta_{\mathrm{Sl}-\mathrm{Gn}}}}-273.15
$$

For example, for a sample with $\delta^{34} \mathrm{~S}_{\mathrm{Sl}}=8.7 \%$ and $\delta^{34} \mathrm{~S}_{\mathrm{Gn}}=6.1 \%$, a temperature of $257{ }^{\circ} \mathrm{C}$ is calculated using Equation (15). Uncertainties in sulfur isotope temperature estimates generally range between \pm 10 and $40{ }^{\circ} \mathrm{C}$ (Ohmoto and Rye 1979).

\section{PROCESSES THAT RESULT IN STABLE ISOTOPIC VARIATIONS OF SULFUR}

Variations in the stable isotopic composition of natural systems can result from a variety of equilibrium and kinetically controlled processes, which span a continuum. These processes can be further divided into mass-dependent and mass-independent fractionation processes. Mass-dependent fractionation processes are the most common in geochemical systems and cause systematic correlations among the various stable sulfur isotopes (i.e., ${ }^{32} \mathrm{~S},{ }^{33} \mathrm{~S},{ }^{34} \mathrm{~S}$, and ${ }^{36} \mathrm{~S}$ ) on the basis of their relative mass differences. As the name implies, mass-independent fractionation does not.

\section{Mass-dependent fractionation processes}

The most important steps for producing mass-dependent sulfur isotopic variations in sulfide minerals are the geochemical processes that initially produce the sulfide from other sulfur species such as sulfate or sulfite, or transform sulfide to other sulfur species, rather than the actual 
precipitation of the sulfide mineral from dissolved sulfide. In addition, the low-temperature rates of many of the oxidation and reduction processes are enhanced by bacterial mediation, which can impart distinct isotopic fractionations to these processes. Thus, the complex aqueous geochemistry of sulfur species is a key aspect for understanding the stable isotope geochemistry of sulfate minerals. Ohmoto (1972) developed the principles for application of sulfur isotope systematics to sulfur speciation in hydrothermal ore deposits. Comprehensive reviews of the controls on the sulfur isotope systematics of sulfides in ore deposits have been given by Ohmoto and Rye (1979), Ohmoto (1986), and Ohmoto and Goldhaber (1997).

Significant isotopic variations may be caused by progressive fractionation processes in a setting where the reservoir of sulfur available is finite, especially where the sulfur isotope fractionation factor between the starting and final sulfur species is large. Under these conditions many equilibrium and kinetic processes can be described as Rayleigh distillation processes. Rayleigh processes are described by the equation:

$$
R=R_{\mathrm{o}} f^{(\alpha-1)}
$$

where $R_{\mathrm{o}}$ is the initial isotopic ratio, $R$ is the isotopic ratio when a fraction $(f)$ of the starting amount remains, and $\alpha$ is the fractionation factor, either equilibrium or kinetic. This equation can be recast in the $\delta$ notation for sulfur isotopes as:

$$
\delta^{34} \mathrm{~S}=\left(\delta^{34} \mathrm{~S}_{\mathrm{o}}+1000\right) f^{(\alpha-1)}-1000
$$

Rayleigh models accurately describe isotopic variations associated with processes such as the precipitation of minerals from solutions, the precipitation of rain or snow from atmospheric moisture, and the bacterial reduction of seawater sulfate to sulfide, among others. Bacterial reduction of seawater sulfate can be modeled using Equation (17). If $\alpha=1.0408$ and $\delta^{34} \mathrm{~S}_{\mathrm{o}}=$ $21.0 \%$, then precipitation of pyrite from $\mathrm{H}_{2} \mathrm{~S}$ produced from bacterial reduction of sulfate will preferentially remove ${ }^{32} S$ and the first pyrite formed will have $\delta^{34} S \approx-20 \%$. The preferential removal of ${ }^{32} \mathrm{~S}$ will cause the $\delta^{34} \mathrm{~S}$ of the residual aqueous sulfate to increase which, in turn, will lead to an increase in the $\delta^{34} \mathrm{~S}$ of subsequently formed pyrite (Fig. 3). Under closed-system behavior, after all sulfate has been reduced, the bulk isotopic $\delta^{34} \mathrm{~S}$ of the precipitated pyrite will equal the $\delta^{34} \mathrm{~S}$ of the initial sulfate. However, the $\delta^{34} \mathrm{~S}$ of individual pyrite grains or growth zones can be both lower and higher than the bulk composition, depending on when they formed.

Mixing is another important process that can cause isotopic variations. It can be modeled on the basis of simple mass-balance equations such as:

$$
\delta_{\text {mixture }}=X_{A} \delta_{A}+X_{B} \delta_{B}
$$

where $\delta_{\text {mixture }}$ is the resulting isotopic composition of the mixture, $\delta_{A}$ and $\delta_{B}$ are the isotopic compositions of components $A$ and $B$, and $X_{A}$ and $X_{B}$ are the mole fractions of components $A$ and $B$.

Kinetics of isotope exchange reactions. The kinetics of isotopic exchange between aqueous sulfate and sulfide at elevated temperatures are important in determining the isotopic composition of sulfide minerals and associated aqueous or solid sulfate. Ohmoto and Lasaga (1982) found that exchange rates between dissolved $\mathrm{SO}_{4}{ }^{2-}$ and $\mathrm{H}_{2} \mathrm{~S}$ decreased with increasing $\mathrm{pH}$ at $\mathrm{pH}<3$; from $\mathrm{pH} \approx 4$ to 7 , the rates remain fairly constant; at $\mathrm{pH}>7$, the rate also decreases with increasing $\mathrm{pH}$. The reason for these changes in rate as a function of $\mathrm{pH}$ is the $\mathrm{pH}$ dependence of sulfur speciation. Ohmoto and Lasaga (1982) proposed that the overall rate of exchange is limited by exchange reactions involving intermediate valence thiosulfate species $\left(\mathrm{S}_{2} \mathrm{O}_{3}{ }^{2-}\right)$, the abundance of which is dependent on $\mathrm{pH}$. The rate-limiting step was postulated to be an intramolecular exchange between non-equivalent sulfur sites in thiosulfate, which has been further investigated by Chu et al. (2004). Ohmoto and Lasaga (1982) calculated the most rapid equilibration rates at high temperature $\left(T=350{ }^{\circ} \mathrm{C}\right)$ and 


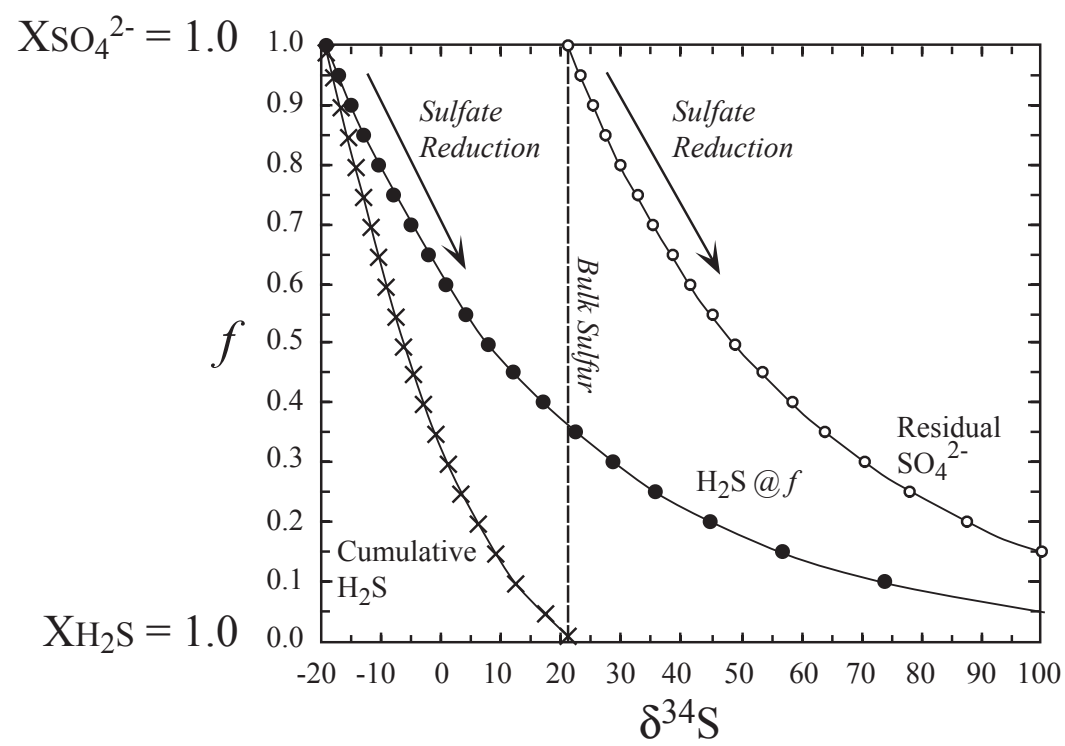

Figure 3. Rayleigh distillation curves for bacterial reduction of seawater sulfate showing the change in $\delta^{34} \mathrm{~S}$ of resultant $\mathrm{H}_{2} \mathrm{~S}$ (filled circles), residual sulfate (open circles), and bulk sulfide (X) as a function of reaction progress. Pyrite precipitated from the $\mathrm{H}_{2} \mathrm{~S}$ would be expected to have a $\delta^{34} \mathrm{~S}$ that is approximately $4 \%$ o higher than that shown for $\mathrm{H}_{2} \mathrm{~S}$ assuming equilibrium fractionation between pyrite and $\mathrm{H}_{2} \mathrm{~S}$. Modified from Ohmoto and Goldhaber (1997) and Seal et al. (2000a). Isotopic values in permil (VCDT).

low $\mathrm{pH}(\mathrm{pH} \approx 2)$ of approximately 4 hours for $90 \%$ equilibrium between aqueous sulfate and sulfide; however, at low temperature $\left(T=25^{\circ} \mathrm{C}\right)$ and near neutral $\mathrm{pH}(\mathrm{pH}=4-7)$, the time to attain $90 \%$ equilibrium reached $9 \times 10^{9}$ years. Thus, disequilibrium between sulfate and sulfide minerals should be prevalent in hydrothermal and geothermal systems below $350{ }^{\circ} \mathrm{C}$, except under extremely acidic conditions (Fig. 4).

Sulfate reduction. Sulfate reduction in natural systems tends to produce characteristic, kinetically controlled, non-equilibrium sulfur isotope fractionations in both biotic and abiotic environments. Isotopic variations associated with the biogenic reduction of sulfate have been studied by numerous researchers, most of whom have concentrated on the role of dissimilatory sulfate-reducing bacteria such as Desulfovibrio desulfuricans. The activity of sulfate-reducing bacteria in marine sediments throughout most of geological time had a profound effect on the sulfur isotope composition of seawater sulfate, which is discussed in a later section.

Sulfate-reducing bacteria are active only in anoxic environments such as below the sediment-water interface, and in anoxic water bodies. Various species of sulfate-reducing bacteria can survive over a range of temperature $\left(0\right.$ to $\left.110^{\circ} \mathrm{C}\right)$ and $\mathrm{pH}(5$ to 9.5$)$ conditions, but prefer near-neutral conditions between 20 and $40{ }^{\circ} \mathrm{C}$ and can withstand a range of salinities from dilute up to halite saturation (Postgate 1984; Canfield 2001). The metabolism of sulfatereducing bacteria can be described by the general reaction:

$$
2 \mathrm{CH}_{2} \mathrm{O}+\mathrm{SO}_{4}{ }^{2-} \rightarrow \mathrm{H}_{2} \mathrm{~S}+2 \mathrm{HCO}_{3}{ }^{-}
$$

where $\mathrm{CH}_{2} \mathrm{O}$ represents generic organic matter (Berner 1985). The $\mathrm{H}_{2} \mathrm{~S}$ can be lost to the water column, reoxidized, fixed as iron-sulfide minerals (i.e., pyrite, mackinawite, greigite) or other sulfide minerals if reactive metals are present, or it can be fixed as organic-bound sulfur. In near-surface sediments deposited under normal (oxygenated) marine settings, the 


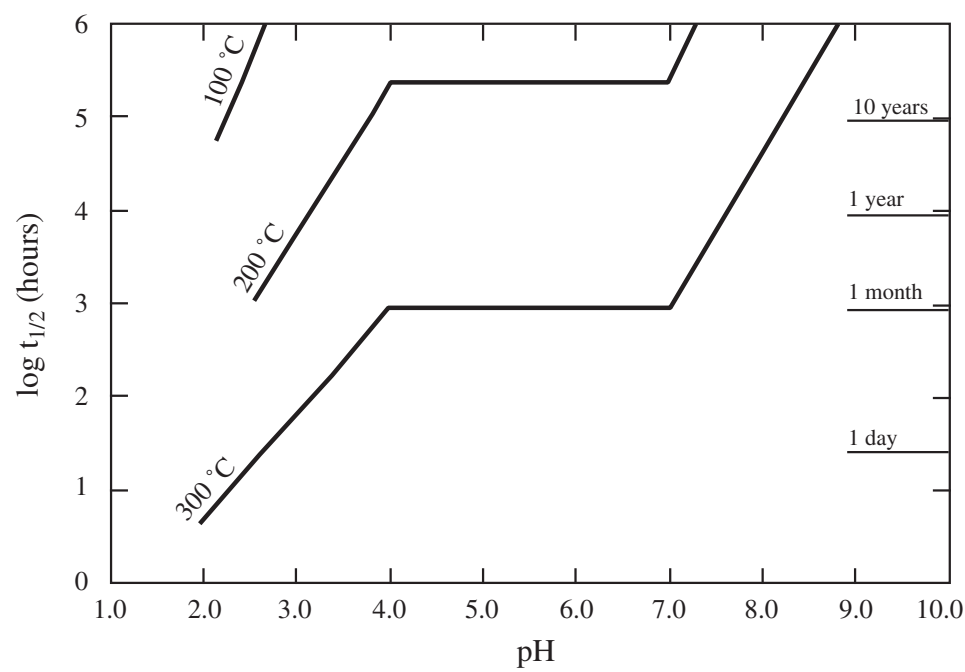

Figure 4. The kinetics of sulfur isotope exchange in terms of $\mathrm{pH}$ and $\log \mathrm{t}_{1 / 2}$ for a solution with $0.1 \mathrm{~m} \Sigma \mathrm{Na}$ and $0.01 \mathrm{~m} \Sigma \mathrm{S}$. The bends in the isotherms are due to changes in the speciation of sulfur as a function of pH. Modified from Ohmoto and Lasaga (1982).

activity of sulfate-reducing bacteria is limited by the supply and reactivity of organic matter; in freshwater and euxinic basins, the activity is limited by sulfate availability (Berner 1985).

The fractionation of sulfur isotopes between sulfate and sulfide during bacterial sulfate reduction is a kinetically controlled process in which ${ }^{34} \mathrm{~S}$ is enriched in the sulfate relative to the sulfide, in the same sense as equilibrium fractionation between sulfate and sulfide (Chambers and Trudinger 1979). The sulfate-reducing bacteria more readily metabolize ${ }^{32} \mathrm{~S}$ relative to ${ }^{34} \mathrm{~S}$. Thus, the $\delta^{34} \mathrm{~S}$ of the residual aqueous sulfate increases during the reaction progress.

The magnitude of the fractionation has been shown to be a function of the rate of sulfate reduction, which can be related to sedimentation rates. The smaller fractionations correspond to faster rates of sulfate reduction and sedimentation, whereas the larger fractionations correspond to slower rates of sulfate reduction and sedimentation (Goldhaber and Kaplan 1975). In contrast, other compilations fail to show such distinct correlations between isotopic fractionation and sedimentation rate (Canfield and Teske 1996). The fractionation associated with bacterial sulfate reduction $\left(1000 \ln _{\mathrm{SO}_{4}-\mathrm{H}_{2} \mathrm{~S}}\right.$ ) typically ranges from 15 to $71 \%$ (Goldhaber and Kaplan 1975; Canfield and Teske 1996) in marine settings, compared to an equilibrium, abiotic fractionation of approximately $73 \%$ at $25^{\circ} \mathrm{C}$. However, Canfield and Teske (1996) and Canfield (2001) noted fractionations ranging only between 4 and $46 \%$ o that can be directly attributed to bacterial sulfate reduction. Canfield (2001) and Habicht and Canfield (2001) suggested that the greater amount of fractionation found in nature may result from the nearubiquitous partial oxidation in marine settings of resultant sulfide, and subsequent isotopic effects associated with disproportionation of intermediate sulfur species.

The isotopic composition of the pyrite resulting from bacterial sulfate reduction depends on how open or closed is the system. In natural settings, evolution of the isotopic system may occur in a closed basin, where the reservoir of sulfate is finite and becoming exhausted, or sulfate availability may be limited due to diagenetic cementation of pore spaces in the sediments which isolates the sulfate undergoing reduction from replenishment. Open systems requires an unlimited source of sulfate and the ability to transport rapidly the sulfate below the sediment-water interface to the site of sulfate reduction. 
Closed-system and open-system behavior, and the gradations between these two extremes, will produce distinctive frequency distributions in the resultant $\delta^{34} S$ values of the pyrite. Seal and Wandless (2003) modeled the spectrum of distribution patterns using a combination of Rayleigh and mixing equations in the context of seawater-sulfate reduction during Ordovician time (Fig. 5a). End-member open system behavior produces a sharp mode that corresponds to the $1000 \ln _{\mathrm{SO}_{4}-\mathrm{H}_{2} \mathrm{~S}}$ value - in their example, 55\%o, which was based on the difference between the inferred seawater composition (28\%o) and the lowest $\delta^{34} S$ value from pyrites in sedimentary rock near the Bald Mountain massive sulfide deposit in northern Maine $(-27 \%$; Fig. 5b). In contrast, end-member closed system behavior does not produce a mode; instead, a flat distribution results from the continued depletion of the sulfate reservoir (Figs. 3 and 5). When diffusive transport of sulfate is just half the rate of reduction, distributions lacking a mode result. When the rate of diffusive transport and reduction are equal, a skewed distribution with a distinct mode is produced. As advective transport exceeds the rate of reduction and diffusive transport, similar skewed distributions are produced with decreasing ranges of values until end-member open-system conditions are reached.

Abiotic (thermochemical) reduction of aqueous sulfate through high-temperature (200 to $350{ }^{\circ} \mathrm{C}$ ) interactions with $\mathrm{Fe}^{2+}$ (fayalite and magnetite) can be modeled as an equilibrium Rayleigh process (Shanks et al. 1981). The $\delta^{34} \mathrm{~S}$ of residual aqueous sulfate increases during reduction in accordance with published equilibrium fractionation factors (Ohmoto and Lasaga 1982; Table 1). Similarly, Sakai et al. (1980) found that sulfur isotope fractionations associated with thermochemical reduction of dissolved sulfate through reaction with olivine $\left(X_{\mathrm{Fo}}=0.90\right)$ at $400{ }^{\circ} \mathrm{C}$ produces results consistent with equilibrium exchange between sulfate and sulfide. Orr (1974) and Kiyosu (1980) documented sulfur isotopic effects associated with thermochemical reduction of sulfate because of the interaction with organic matter, and found that sulfate-sulfide kinetic fractionation was less than $10 \%$.

Sulfide oxidation. The oxidative weathering of sulfide minerals to form sulfate minerals or aqueous sulfate is a quantitative, unidirectional process that produces negligible sulfurisotope fractionation. The $\delta^{34} \mathrm{~S}$ of resulting sulfate is indistinguishable from that of the parent sulfide mineral; likewise, the isotopic composition of residual sulfide minerals is unaffected (Gavelin et al. 1960; Nakai and Jensen 1964; Field 1966; Rye et al. 1992). Gavelin et al. (1960) and Field (1966) documented similar sulfur isotope compositions among hypogene sulfide ore minerals and various associated supergene sulfate minerals. A similar conclusion was reached regarding the relationship of aqueous sulfate with sulfide minerals in acid mine drainage settings. Taylor and Wheeler (1994) and Seal (2003) found no discernible difference between $\delta^{34} \mathrm{~S}$ in the parent sulfides and the associated dissolved sulfate. In contrast, the oxygen

Figure 5 (on facing page). Hypothetical sulfur isotope composition of sedimentary pyrites formed under different rates of sulfate transport relative to sulfate reduction. Modified from Seal and Wandless (2003). (a) Sulfur isotope evolution of sedimentary pyrite related to bacterial sulfate reduction and diffusive and advective transport into pore spaces below the sediment-water interface for conditions approximating the inferred seafloor environment of Bald Mountain (Maine). Calculations were made at reduction steps of $0.282 \mathrm{mmol}$ of $\mathrm{SO}_{4}$. Calculations for no diffusion of sulfate into the system are identical to closed-system Rayleigh behavior. For calculations with the rate of diffusion less than the rate of reduction, the sulfate supply will become exhausted, resulting in the most positive $\delta^{34} \mathrm{~S}$ values for pyrite near the last reduction

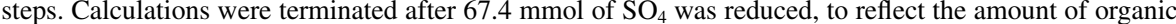
carbon available for reduction in typical marine sediments. Note that only in cases where the rate of reduction is faster than the rate of diffusion is the $\delta^{34} \mathrm{~S}$ value for pyrite found to be higher than for coeval seawater. For conditions where the rate of advective transport is greater than the rate of reduction, the isotopic evolution is modeled as mixtures of residual sulfate and pristine seawater sulfate (curves labeled $X_{\mathrm{SW}}=0.0$ to 1.0). (b) Hypothetical histograms for the sulfur isotope composition of sedimentary pyrites for various rates of sulfate reduction and sulfate transport by diffusion and advection, compared to the isotopic composition of pyrites from the graphitic argillite found at the Bald Mountain deposit, Maine (Seal and Wandless 2003). All isotopic values are given in permil (VCDT). 

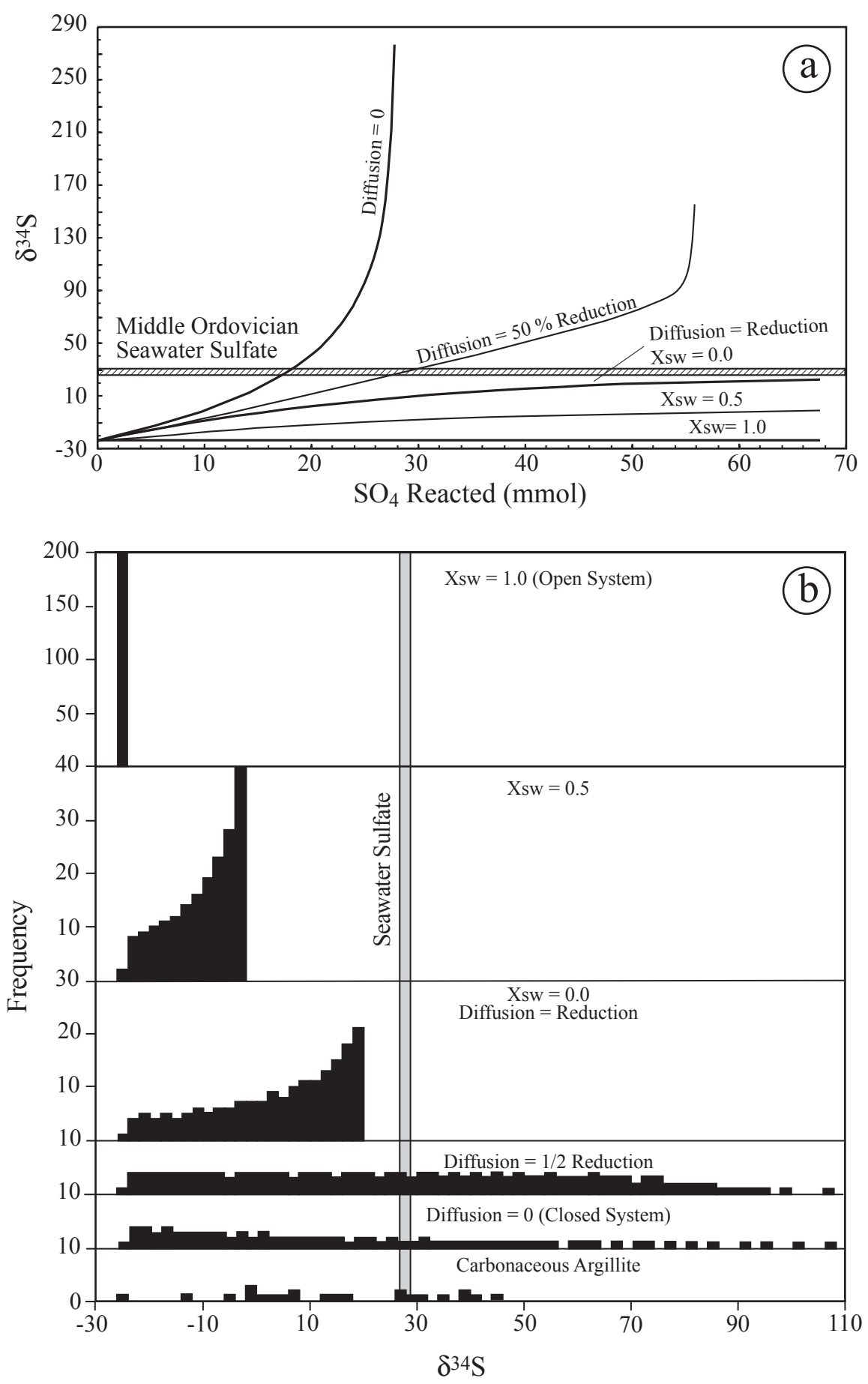

Figure 5. Caption on facing page. 
isotope composition of sulfate derived from the oxidative weathering of sulfide minerals shows significant variations depending upon the oxygen isotopic composition and $\mathrm{pH}$ of the associated water, and the oxidizing agent (i.e., oxygen or ferric iron), among other factors (Taylor and Wheeler 1994; Seal 2003).

Mechanisms of sulfide precipitation. Precipitation mechanisms for sulfide minerals and their associated environment can have significant affects on the sulfur isotopic fractionation between minerals, as discussed by Ohmoto and Goldhaber (1997). For simple sulfides such as $\mathrm{ZnS}, \mathrm{PbS}$ and $\mathrm{Fe}_{1-x} \mathrm{~S}$, the relative proportions of metal and $\mathrm{H}_{2} \mathrm{~S}$ are important. These minerals can be precipitated through simple cooling, dilution to destabilize chloride complexes, or acid neutralization. Under conditions where the molalities of dissolved metals exceed that of $\mathrm{H}_{2} \mathrm{~S}$, as is commonly found during precipitation of monometallic ores, disequilibrium fractionations are expected where the observed fractionation is less than that expected under equilibrium conditions. This discordance is due to the fact that sulfur needs to be obtained at the site of sulfide deposition. The mineral that reaches saturation first will consume a significant portion of the $\mathrm{H}_{2} \mathrm{~S}$ reservoir causing a shift through Rayleigh processes in the isotopic composition the residual $\mathrm{H}_{2} \mathrm{~S}$ available for later minerals. Sulfide minerals from polymetallic ores formed from fluids where the concentration of $\mathrm{H}_{2} \mathrm{~S}$ greatly exceeds those of the metals, generally show equilibrium fractionation between simple sulfides because of their precipitation resulted from being mutually saturated rather than from one metal becoming exhausted in the fluid so that next metal can reach saturation.

The precipitation of pyrite and chalcopyrite is more complex because it typically requires an oxidation step in addition to other depositional mechanisms (Ohmoto and Goldhaber 1997). For example, pyrite has disulfide $\left(\mathrm{S}_{2}{ }^{2-}\right)$ rather than sulfide $\left(\mathrm{S}^{2-}\right)$ anion units in its structure. Likewise, chalcopyrite precipitation can commonly involve oxidation-reductions reactions of iron and copper. Replacement is another important mechanism for the formation of chalcopyrite where the isotopic composition may be inherited partly, or wholly, from the precursor mineral. Thus, because of the greater complexity of precipitation mechanisms for pyrite and chalcopyrite, equilibrium isotopic fractionations with other sulfide minerals are less likely.

Disproportionation of $\mathrm{SO}_{2}$. Sulfur dioxide $\left(\mathrm{SO}_{2}\right)$ is the most important oxidized sulfur species in high $\mathrm{fO}_{2}$ magmatic-hydrothermal systems; $\mathrm{H}_{2} \mathrm{~S}$ is the dominant reduced sulfur species. Upon cooling below $\sim 400{ }^{\circ} \mathrm{C}$, the $\mathrm{SO}_{2}$ undergoes hydrolysis or disproportionation described by the reaction:

$$
4 \mathrm{H}_{2} \mathrm{O}+4 \mathrm{SO}_{2} \rightarrow \mathrm{H}_{2} \mathrm{~S}+3 \mathrm{H}^{+}+3 \mathrm{HSO}_{4}^{-}
$$

producing $\mathrm{H}_{2} \mathrm{~S}$ and $\mathrm{SO}_{4}{ }^{2-}$ (Holland 1965; Burnham and Ohmoto 1980). The isotopic effects associated with the disproportionation of $\mathrm{SO}_{2}$ will be discussed below in the sections of porphyry and epithermal mineral deposits.

\section{Mass-independent fractionation processes}

Non mass-dependent fractionation or "mass-independent" fractionation refers to processes that cause variations in the abundances of isotopes that are independent of their masses. In mass-dependent fractionation, variations in ${ }^{34} \mathrm{~S} /{ }^{32} \mathrm{~S}$ should be approximately twice those of ${ }^{33} \mathrm{~S} /{ }^{32} \mathrm{~S}$, and approximately half those of ${ }^{36} \mathrm{~S} /{ }^{32} \mathrm{~S}$ (Hulston and Thode 1965a); likewise, the fractionation of ${ }^{17} \mathrm{O} /{ }^{16} \mathrm{O}$ should be approximately half that of ${ }^{18} \mathrm{O} /{ }^{16} \mathrm{O}$ (Bigeleisen and Mayer 1947; Urey 1947). On geochemical plots of one isotopic ratio versus another, for example $\delta^{33} \mathrm{~S}$ versus $\delta^{34} \mathrm{~S}$, or $\delta^{17} \mathrm{O}$ versus $\delta^{18} \mathrm{O}$, samples that have experienced mass-dependent fractionation processes would fall along a line known as a mass-fractionation line, which has a slope corresponding to the relative mass difference between the two ratios. The Earth-Moon system has characteristic mass-fractionation lines for sulfur and oxygen isotopes because all of the isotopes are well mixed in these bodies. Deviations from these lines, or "isotope anomalies" 
reflect mass-independent fractionation processes. For sulfur isotopes, these deviations are expressed as non-zero $\Delta^{33} \mathrm{~S}$ and $\Delta^{36} \mathrm{~S}$ values, which are defined respectively as:

$$
\begin{aligned}
& \Delta^{33} S=\delta^{33} S-1000\left[\left(1-\frac{\delta^{34} S}{1000}\right)^{0.515}-1\right] \\
& \Delta^{36} S=\delta^{36} S-1000\left[\left(1-\frac{\delta^{34} S}{1000}\right)^{1.91}-1\right]
\end{aligned}
$$

where 0.515 and 1.91 are the approximate slopes on the respective $\delta$ - $\delta$ diagrams, and represent deviations from the terrestrial fractionation line.

Some of the earliest identified isotopic anomalies were found in the oxygen isotope compositions of meteorites, which can be interpreted to reflect heterogeneity in the early history of the solar system (Clayton 1986). In fact, most meteorite types fall off the terrestrial oxygen isotope mass-fractionation line. Sulfur isotopic anomalies in meteorites, discussed below, are less impressive.

Photochemical processes in the upper atmosphere have been found to cause massindependent fractionations in sulfur and oxygen isotopes (Farquhar and Wing 2003; Rumble 2005). Sulfur isotope anomalies, presumably derived from upper atmospheric ultraviolet radiation-induced photochemical processes, have been identified in pyrite, pyrrhotite, chalcopyrite, and galena, in addition to sulfate minerals, in the Archean geologic record (Farquhar et al. 2000a; Hu et al. 2003; Mojzsis et al. 2003; Ono et al. 2003; Bekker et al. 2004). Prior to $2.4 \mathrm{Ga}$, sulfide and sulfate values from a variety of geologic settings are variably anomalous, with $\Delta^{33} \mathrm{~S}$ values for sulfides and sulfates ranging from -2.5 to $8.1 \%$ (Farquhar et al. 2000a; Ono et al. 2003; Rumble 2005). Since $2.4 \mathrm{Ga}$, samples have a much more limited range of $\Delta^{33} \mathrm{~S}$ from -0.5 to $0.7 \%$ (Fig. 6; Savarino et al. 2003; Bekker et al. 2004). The abrupt change in the magnitude of the anomalous mass-independent fractionations around $2.4 \mathrm{Ga}$ has been interpreted as reflecting the development of an oxygenated atmosphere. The increase in the partial pressure of oxygen would have been conducive to the development of an ozone layer, which would have shielded lower parts of the atmosphere from photochemical processes induced by ultraviolet radiation; in addition, the associated lower abundances of reactive, more reduced sulfur species in the atmosphere may have also contributed to the abrupt end of mass-independent anomalies (Farquhar et al. 2000a; Pavlov and Kasting 2002; Farquhar and Wing 2003; Bekker et al. 2004).

Figure 6. Age distribution of sulfur isotope anomalies in sedimentary rocks. Modified from Rumble (2005), and includes data from Bekker et al. (2004), Farquhar et al. (2000a), Hu et al. (2003), Mojzsis et al. (2003), and Ono et al. (2003).

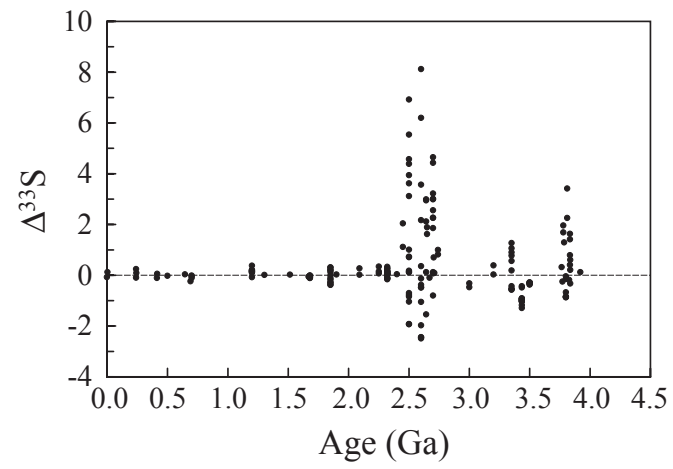




\section{GEOCHEMICAL ENVIRONMENTS}

The scientific literature concerning sulfur isotopes from sulfide minerals is voluminous, and that pertaining to mineral deposits is overwhelming. Therefore, the following sections on specific geochemical environments will focus on examples to illustrate important aspects of sulfur isotope geochemistry from high- and low-temperature settings. An attempt was made to balance coverage of pioneering studies with that of emerging ideas and applications of sulfur isotopes from sulfide minerals.

\section{Meteorites}

Sulfur isotope data have provided a variety of insights into the origins of the Earth and the solar system as recorded by meteorites. Sulfur isotope compositions have been determined for a variety of sulfide minerals in meteorites, including troilite, pyrrhotite, pyrite, chalcopyrite, pentlandite, oldhamite $(\mathrm{CaS})$, alabandite $(\mathrm{MnS})$, and daubreelite $\left(\mathrm{FeCr}_{2} \mathrm{~S}_{4}\right)$ among others, in addition to sulfate, sulfur in solid solution in native iron, and a variety of species that are extractable with various solvents. The earliest researchers investigating the sulfur isotope composition of meteorites found remarkably constant and fairly homogeneous compositions among all types of meteorites, with the $\delta^{34} \mathrm{~S}$ of most falling between -2.5 and 2.5\%o (Fig. 7; Macnamara and Thode 1950; Hulston and Thode 1965a; Monster et al. 1965; Kaplan and Hulston 1966) which is in stark contrast to the oxygen isotope compositions of meteorites, which varies widely (Clayton 1986). In fact, it was this restricted compositional range, particularly for troilite from iron meteorites, that led to the designation of Canyon Diablo troilite as the basis for the sulfur isotope scale. The isotopic composition of meteoritic sulfur is also used as a reference point for the bulk earth from which to evaluate global scale fractionations in the sulfur cycle.

Local evidence has been found for secondary alteration of the sulfur isotopic composition in a limited number of meteorites that reflects aqueous processes occurring on the parent bodies from which the meteorites came. In the SNC type meteorites, which likely originated on Mars, Shearer et al. (1996) identified vug-filling pyrite with unusually high $\delta^{34} \mathrm{~S}$ between 4.8 and $7.8 \%$, probably reflecting Martian hydrothermal alteration. Greenwood et al. (2000a)

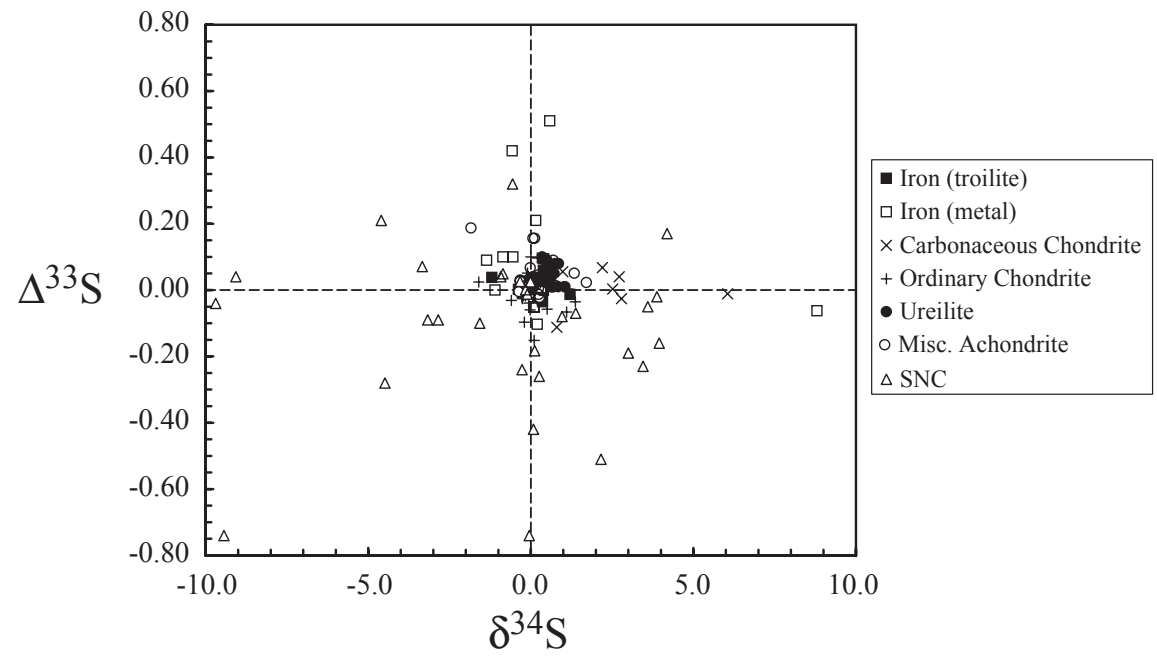

Figure 7. Sulfur isotope composition of meteorites plotted in terms of $\Delta^{33} S$ and $\delta^{34} S$. See text for sources of data. Dashed lines indicate $0 \%$. Isotopic values are given in permil (VCDT). 
also found $\delta^{34} \mathrm{~S}$ values in Martian meteorites ranging from -6.1 to $4.9 \%$, that were consistent with hydrothermal alteration, in pyrrhotite, pyrite, and chalcopyrite, some of which was vein filling. McSween et al. (1997) found texturally unique pyrrhotite and pentlandite in a carbonaceous chondrite having $\delta^{34} \mathrm{~S}$ values between -4.2 and $1.1 \%$, and -5.7 and $-3.0 \%$, respectively, which were interpreted to be the result of alteration on the asteroid on which the chondrites originated. In another carbonaceous chondrite, Monster et al. (1965) found sulfur isotopic compositions for sulfide $\left(\delta^{34} \mathrm{~S}=2.6 \%\right.$ ) , native sulfur $\left(\delta^{34} \mathrm{~S}=1.5 \%\right.$ ) and sulfate $\left(\delta^{34} \mathrm{~S}=-1.3 \%\right.$ o $)$ that clearly reflect disequilibrium conditions.

Mass-independent sulfur isotopic anomalies have also been identified in meteorites. Such anomalies can be generated by mixing of sulfur from different nucleosynthetic reservoirs (Clayton and Ramadurai 1977), cosmic-ray induced reactions involving iron (Hulston and Thode 1965a; Gao and Thiemens 1991), and photochemical and other chemical reactions (Farquhar et al. 2000b). Evidence for mixing of different nucleosynthetic reservoirs has been elusive in sulfur isotopes. Rees and Thode (1977) found a $1 \%{ }^{33} \mathrm{~S}$ anomaly in the Allende carbonaceous chondrite, but subsequent researchers analyzing Allende were unable to find additional evidence (Gao and Thiemens 1993a). Enstatite chondrites and ordinary chondrites, which come from other primitive asteroids, generally lack sulfur isotopic anomalies (Gao and Thiemens 1993b). The most compelling evidence for nebular sulfur heterogeneity is the small, but distinguishable ${ }^{33} \mathrm{~S}$ anomalies $\left(\Delta^{33} \mathrm{~S}=0.042 \%\right.$ o $)$ found in ureilites, a type of achondrite associated with carbonaceous chondrites (Farquhar et al. 2000c). However, Rai et al. (2005) attributed mass-independent anomalies in other achrondritic meteorites to photochemical processes in the early solar nebula. The sulfur dissolved in the metallic phase of iron meteorites, which are the cores of differentiated asteroids, can have $\Delta^{33} \mathrm{~S}$ and $\Delta^{36} \mathrm{~S}$ values up to 2.7 and $21.5 \%$, respectively, that are consistent with cosmic-ray induced spallation reactions, and have a characteristic $\Delta^{36} \mathrm{~S} / \Delta^{33} \mathrm{~S}$ ratio of $\sim 8$ (Gao and Thiemens 1991).

The largest mass-independent anomalies, not from metallic or organic phases in meteorites, were found in Martian (SNC) meteorites where $\Delta^{33} \mathrm{~S}$ ranges from -0.302 to $0.071 \%$ o (Fig. 7); $\Delta^{36} \mathrm{~S}$ values range from 0.0 to $2.6 \%$ (Farquhar et al. 2000b). Farquhar et al. (2000b) attributed these anomalies to UV-induced photochemical reactions in the Martian atmosphere. Greenwood et al. (2000b) suggested that an additional component of the ${ }^{33} \mathrm{~S}$ anomaly may have resulted from inherited nebular material in the Martian regolith that, unlike on Earth, was not homogenized into the bulk planet due to the lack of tectonic processes on Mars.

\section{Marine sediments}

The modern oceanic sulfur cycle reflects the mass balance among inputs from the erosion of sulfides and sulfates on the continents, removal through the formation of diagenetic sulfide minerals, and evaporative precipitation of sulfate locally along the margins of the oceans (Claypool et al. 1980). Volcanic outgassing and subduction of sedimentary rocks also play significant roles in the addition and subtraction, respectively, of sulfur relative to the oceanic reservoir, particularly prior to the presence of an oxygenated atmosphere (Canfield 2004). The sulfur isotopic composition of sedimentary sulfide minerals has been intimately linked to the sulfur isotopic composition of dissolved sulfate in the oceans, at least since $\sim 2.4$ $\mathrm{Ga}$ - the inferred onset of significant partial pressures of oxygen in the atmosphere (Farquhar et al. 2000a; Pavlov and Kasting 2002; Mojzsis et al. 2003). The link between the isotopic compositions of dissolved sulfate and sedimentary sulfides is caused by the activity of sulfatereducing bacteria as discussed above.

Modern seawater sulfate has a globally homogenous $\delta^{34} \mathrm{~S}$ of $21.0 \pm 0.2 \%$ (Rees et al. 1978). In contrast, the $\delta^{34} \mathrm{~S}$ of modern sedimentary sulfide, mostly pyrite, is quite variable, depending upon setting and ranging between -50 and 20\%o, although most values are negative (Fig. 8; Chambers 1982; Sælen et al. 1993; Strauss 1997). This range includes anoxic settings 


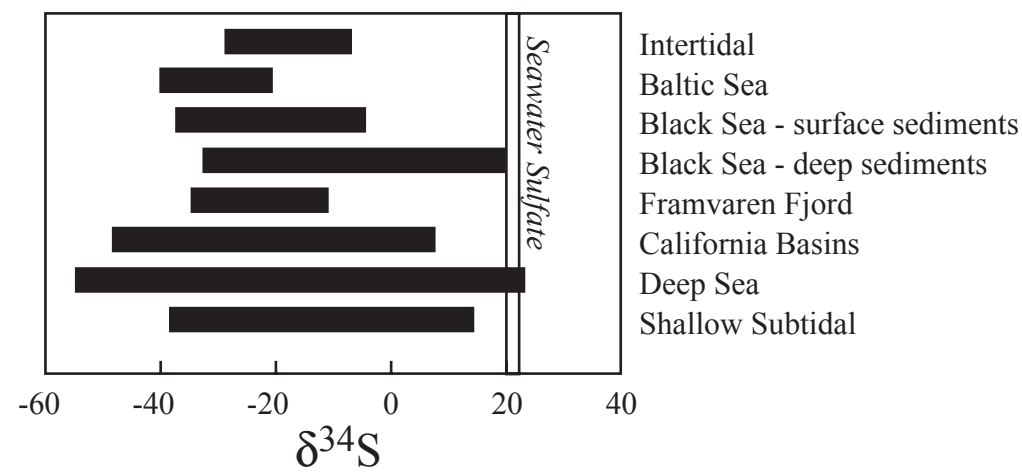

Figure 8. Range of sulfur isotopic values of sedimentary sulfides from a variety of settings compared to seawater sulfate (modified from Strauss 1997). Isotopic values are given in permil (VCDT).

such as the Black Sea and the Framvaren fjord (Norway), and oxic settings ranging from the deep sea to shallow subtidal and intertidal settings (Chambers 1982; Strauss 1997).

Marine sulfate as preserved in evaporite deposits and disseminated in marine sediments provides a robust record of past variations in the isotopic composition of sulfate in the oceans. It has pronounced secular trends in both $\delta^{34} \mathrm{~S}$ and $\delta^{18} \mathrm{O}$, which can be interpreted in terms of these processes (Holser et al. 1979; Claypool et al. 1980). The secular variations in the isotopic compositions of sedimentary sulfide minerals is less distinctive because Rayleigh fractionation of sulfur isotopes during diagenetic bacterial sulfate reduction typically causes a wide range of largely negative $\delta^{34} S$ values within a given sedimentary unit (Hayes et al. 1992; Strauss 1997; Canfield 2004). Numerous studies have investigated or reviewed the sulfur and oxygen isotope systematics of modern and ancient marine sulfate and sulfide (Holser et al. 1979; Claypool et al. 1980; Hayes et al. 1992; Strauss 1997; Seal et al. 2000a; Canfield 2004).

Ancient seawater sulfate had mean $\delta^{34} \mathrm{~S}$ values that varied from around $4 \%$ at $3.4 \mathrm{Ga}$, to a high of $33 \%$ o during Cambrian time, to a Phanerozoic low of about $10 \%$ o during Permian and Triassic time, and ultimately to a modern value around 21\%o (Fig. 9). The mean $\delta^{18} \mathrm{O}$ of marine evaporitic sulfate has varied from around $17 \%$ at 900 Ma to a Phanerozoic low of $10 \%$ o during Permian time, to a modern value of $13 \%$. The $\delta^{18} \mathrm{O}$ of modern seawater sulfate is also homogeneous throughout the oceans with a value of 9.5\% (Longinelli and Craig 1967; Nriagu et al. 1991). The limited range of sulfur and oxygen isotope compositions for any given time in geologic history results from the rapid mixing time of seawater ( 1,000 years) relative to the residence time of sulfate in seawater $\left(8 \times 10^{6}\right.$ years; Holland 1978).

One of the most important milestones in the sulfur cycle of the Earth was the development of an oxic atmosphere around 2.4 Ga (Farquhar et al. 2000a; Pavlov and Kasting 2002; Mojzsis et al. 2003; Bekker et al. 2004). Prior to that time, both sedimentary sulfides and sulfates had limited ranges in $\delta^{34} \mathrm{~S}$ and clustered near $0 \%$ (Fig. 9), the inferred value of the bulk Earth because, in the absence of significant concentrations of oxygen in the atmosphere and, therefore, sulfate in seawater, there were few mechanisms available to fractionate sulfur isotopes. As atmospheric concentrations of oxygen increased, the $\delta^{34} \mathrm{~S}$ of seawater sulfate increased and that of sedimentary sulfides decreased (Fig. 9). Coincident with the divergence of sulfate and sulfide $\delta^{34} \mathrm{~S}$ values was the abrupt disappearance of mass-independent sulfur isotope anomalies in sedimentary sulfides and sulfates (Fig. 6), presumably because of the development of an ozone layer which had the effect of shielding the atmosphere from UVinduced photochemical reactions known to cause mass-independent anomalies (Farquhar et al. 2000a; Bekker et al. 2004). 
Another abrupt change in the sulfur isotope compositions of sedimentary sulfides and seawater sulfate occurred around $0.7 \mathrm{Ga}$ when sedimentary sulfide $\delta^{34} \mathrm{~S}$ values became more negative and those for seawater sulfate became more variable (Fig. 9). Canfield and Teske (1996) and Canfield (2004) interpreted this change as reflecting a greater level of oxygenation of the oceanic water column, even though episodes of deep water anoxia occurred periodically throughout the Phanerozoic (Leggett 1980).

\section{Coal}

The sulfur geochemistry of coal, including its stable isotopes, has been an important research topic because of its use in evaluating coal quality and environmental concerns such as acid rain and acid mine drainage. Sulfur isotope studies have been published for sulfide minerals in coals from the USA (Price and Shieh 1979; Westgate and Anderson 1982; Hackley and Anderson 1986; Whelan et al. 1988; Lyons et al. 1989; Spiker et al. 1994), Australia (Smith and Batts 1974; Smith et al. 1982), China (Dai et al. 2002), Japan (Shimoyama et al. 1990) and the Czech Republic (Bouška and Pešek 1999) among others. Isotopic data are available for a variety of sulfur species including pyrite, marcasite, sphalerite, sulfate (mostly secondary), elemental sulfur, and organic sulfur. Collectively, the coals exhibit a wide range of $\delta^{34} \mathrm{~S}$ values for pyrite (and marcasite), sphalerite, and organic sulfur ranging from -52.6 to $43.1 \%$ o, -14.6 to $18.7 \%$ o, and -18.7 to $30.6 \%$, respectively (Fig. 10).

Sulfur in coal is generally interpreted as coming either from sulfur in source plant material or from the bacterial reduction of aqueous sulfate. Sulfides derived from bacterial sulfate reduction may form near the time of original deposition of the peat, during diagenesis, or during coalification (Spiker et al. 1994). Most of the sulfur in low-sulfur coals generally is organicly bound sulfur, which has been interpreted to be derived from the original plant material (Price and Shieh 1979; Hackley and Anderson 1986). The isotopic composition of primary plant sulfur should be similar to the isotopic composition of its source-dissolved sulfate-because the assimilation of sulfur by plants during growth only results in minimal fractionation of sulfur isotopes (Chambers and Trudinger 1979). Most modern oxygenated fresh waters have $\delta^{34} \mathrm{~S}$ values of dissolved sulfate ranging between 0 and $10 \%$ (Nriagu et al. 1991), which may be analogous to the source waters. Price and Shieh (1979) and Hackley and Anderson (1986) found $\delta^{34} \mathrm{~S}$ values for organic sulfur from low-sulfur coal were generally between 0 and $10 \%$, with no correlation with the $\delta^{34} S$ of associated pyrite. However, Price and Shieh (1986) noted a strong correlation between the $\delta^{34} S$ for pyrite and organic sulfur, which they interpreted to reflect the post-depositional mineralization of organic matter associated with the activity of sulfate-reducing bacteria. This correlation between the $\delta^{34} \mathrm{~S}$ of pyrite and organic sulfur (OS) in coal and oil shale can be described by the equation:

$$
\delta^{34} \mathrm{~S}_{\mathrm{Py}}=1.16 \delta^{34} \mathrm{~S}_{\mathrm{OS}}-4.8
$$

which implies that the pyrite-organic sulfur isotope fractionation $\left(\Delta_{\mathrm{Py}-\mathrm{OS}}\right)$ is $-4.8 \%$ (Fig. 11). The data compiled in Figure 11 indicate that this equation provides a reasonable description 


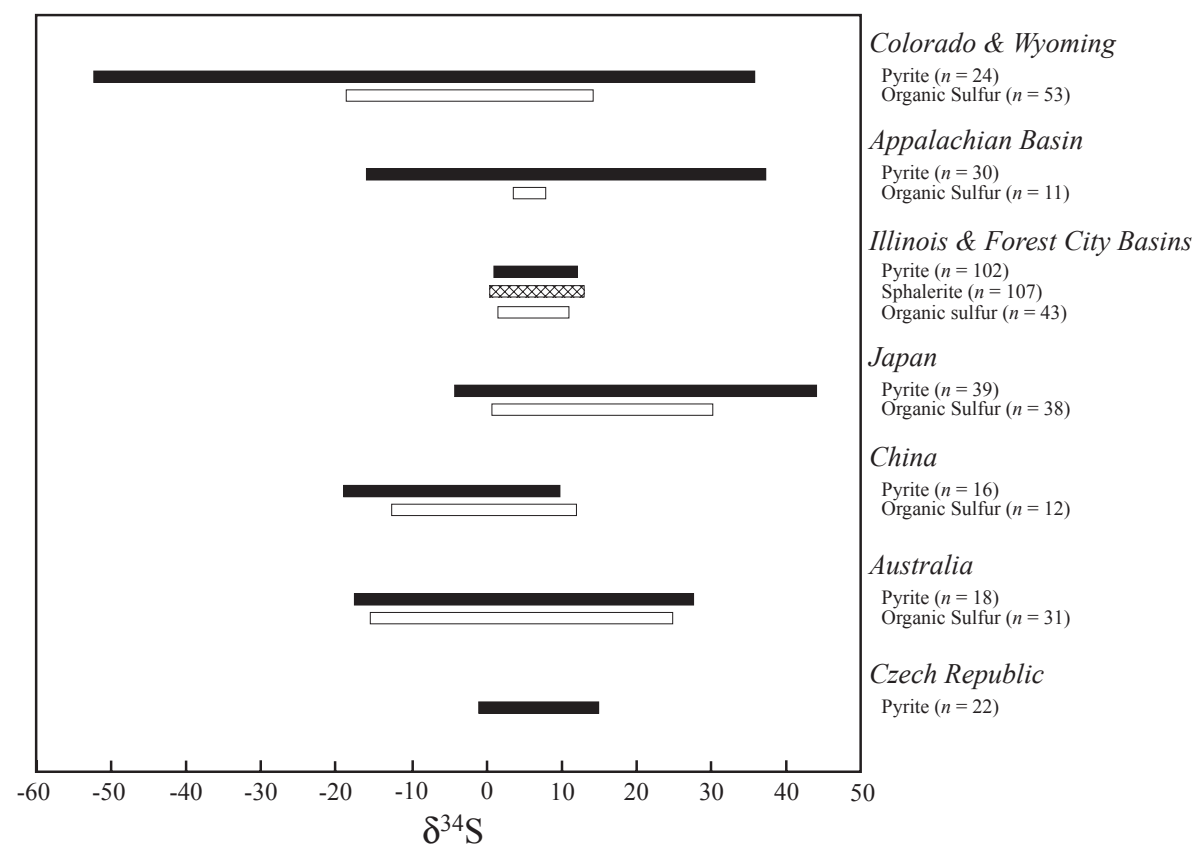

Figure 10. Range of sulfur isotope values from pyrite, sphalerite, and organicly bound sulfur from coals throughout the world. See text for sources of data. Isotopic values are given in permil (VCDT).

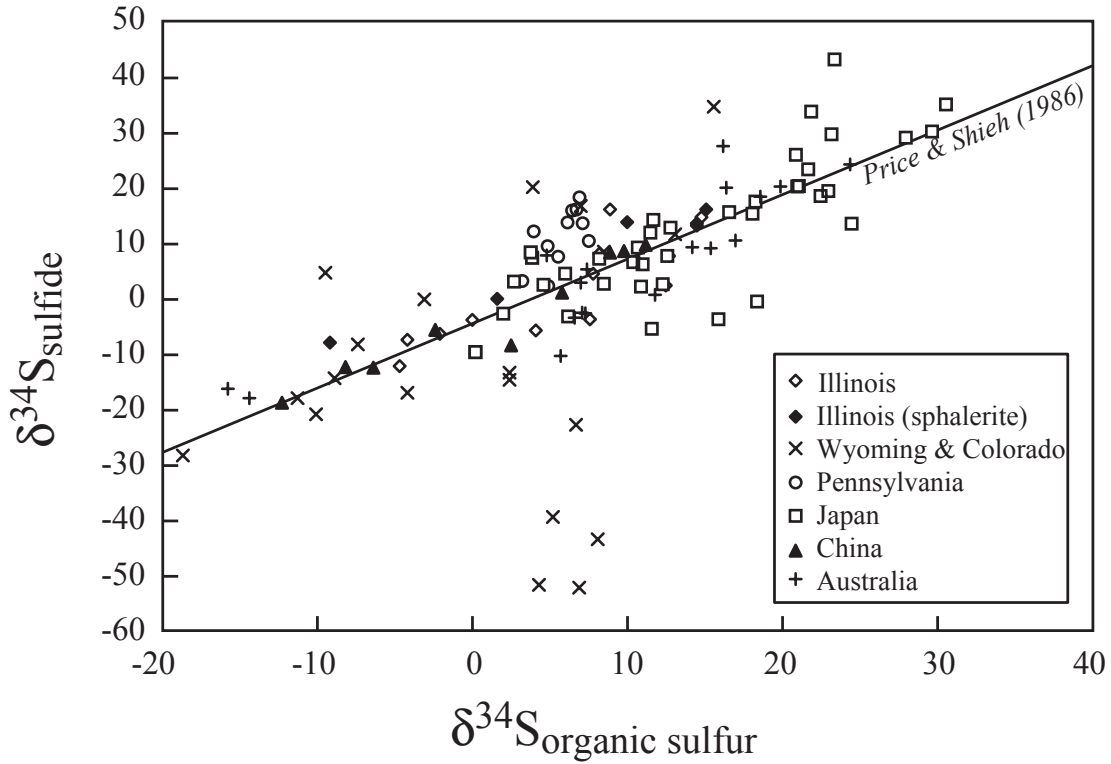

Figure 11. Sulfur isotopic composition of coal in terms of the $\delta^{34} S$ of pyrite and organic bound sulfur. The line describing the covariation of $\delta^{34} S_{\text {Pyrite }}$ and $\delta^{34} S_{\text {Orgainc S }}$ is from Price and Shieh (1986). Isotopic values are given in permil (VCDT). 
of sulfide and organic-sulfur sulfur isotopes from coal beds around the world. Shimoyama et al. (1990) identified correlations with slopes ranging between 1.38 and 1.44 , which require some additional process beyond Rayleigh fractionation during bacterial sulfate reduction to explain their data from Japanese coals. Mixing between primary sulfur from the original plant material, and sulfide derived from bacterial sulfate reduction, is a possible explanation.

Sulfur isotopes from sulfides are also useful for fingerprinting the incursion of seawater into coal-forming systems. Two general isotopic profiles have been identified, as described by Smith and Batts (1974). In the first case, where the rate of bacterial sulfate reduction is greater than the rate of downward sulfate supply, as documented in the Pelton coal seam (Australia), the total mass of pyrite $(\sim 0.8 \mathrm{wt} \%)$ and its $\delta^{34} \mathrm{~S}(\sim 25 \%)$ are high near the top of the coal bed, but decrease rapidly with depth $(<0.1 \mathrm{wt} \%$ and $\sim-3 \%$, respectively). This pattern was interpreted to reflect rapid, quantitative reduction of isotopically heavy seawater sulfate at the top of the section, giving way to plant-derived sulfur at depth. The second case, where the rate of downward supply is greater than that for reduction, the pyrite at top has a lower $\delta^{34} \mathrm{~S}$ value due to the kinetic fractionation between sulfate and sulfide during bacterial sulfate reduction, but increases progressively with depth due to Rayleigh processes. Smith and Batts (1974) observed this pattern in the Garrick seam (Australia). Lyons et al. (1989) observed a similar pattern in a more detailed data set from the Lower Bakerstown coal bed (Maryland, U.S.A.) (Fig. 12). Whelan et al. (1988) noted a similarity between the isotopic compositions of sphalerite in coal beds in the northern part of the Forest City Basin and those in the nearby Upper Mississippi Valley $\mathrm{Zn}-\mathrm{Pb}$ deposits, and suggested that some of the sulfur in the coal beds may have been derived from basinal brines.

\section{Mantle and igneous rocks}

Insights into the sulfur isotopic composition of the mantle can be obtained from mantle xenoliths, diamonds, and primitive igneous rocks, presumably derived from the mantle.

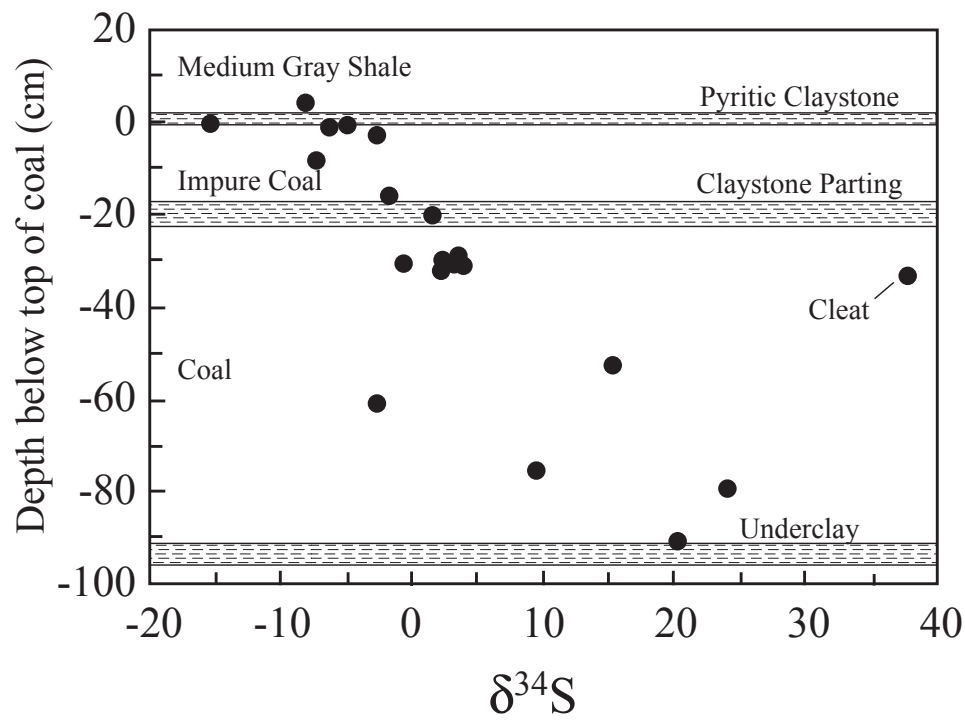

Figure 12. Sulfur isotope composition of pyrite from a cross section through the Bakerstown coal bed, Maryland, USA. (modified from Lyons et al.1989). The section is interpreted to represent the downward incursion of seawater and the associated bacterial sulfate reduction. Compare profile with sulfide curve in Figure 3 at various fractions of reduction $\left(\mathrm{H}_{2} \mathrm{~S} @ f\right)$. Isotopic values are given in permil (VCDT). 
Sulfur isotope studies of igneous rocks unrelated to sulfide-bearing mineral deposits are limited, but shed light on the processes of partial melting and assimilation of country rocks. Sulfide minerals that have been analyzed from mantle and other igneous settings unrelated to hydrothermal activity include pyrrhotite, pyrite, pentlandite, chalcopyrite, monosulfide solid solution, and intermediate solid solution.

The sulfur isotopic composition of the mantle has traditionally been considered to be 0 $\pm 2 \%$ o, similar to meteoritic compositions (Thode et al. 1961), but evidence suggests that the sulfur isotope composition is heterogeneous. The $\delta^{34} \mathrm{~S}$ values of sulfide inclusions in mantle xenoliths $\left(\delta^{34} \mathrm{~S}=1.3 \pm 3.8 \%\right.$ ) , sulfide in mid-ocean ridge (MORB; $\delta^{34} \mathrm{~S}=-0.3 \pm 2.3 \%$ ) and oceanic island basalts (OIB; $\delta^{34} \mathrm{~S}=1.0 \pm 1.9 \%$ ), both of which are thought to represent mantle melts, and related gabbros are quite variable (Sakai et al. 1984; Chaussidon et al. 1989; Torssander 1989) but cluster around 0\%o (Fig. 13). For the basalt, some of the variability in sulfide $\delta^{34} \mathrm{~S}$ values can be attributed to isotopic exchange between sulfide and sulfate and variable sulfide:sulfate ratios in the magmas (Sakai et al. 1984).

The isotopic composition of sulfide inclusions in diamonds are remarkably variable having an average composition of $\delta^{34} \mathrm{~S}=1.2 \pm 5.6 \%$, and a range from -11 to $14 \%$ (Fig. 13; Chaussidon et al. 1987; Eldridge et al. 1991; Farquhar et al. 2002). Peridotitic diamonds, generally considered to have a strictly mantle provenance, typically have $\delta^{13} \mathrm{C}$ values around $-7 \%$ and sulfide inclusions with $\delta^{34} \mathrm{~S}$ values clustering between -5 and 5\%o (Eldridge et al. 1995). In contrast, eclogitic diamonds, which have been interpreted to reflect the subduction of biogenic carbon and sulfur into the mantle (Eldridge et al. 1995), have $\delta^{13} \mathrm{C}$ values reaching below $-30 \%$ and $\delta^{34} \mathrm{~S}$ values of sulfide inclusion spanning the entire range observed in diamonds (-11 to 14\%o). This interpretation is further supported by Farquhar et al. (2002) who found mass-independent anomalies in the sulfur isotope composition of sulfide inclusions hosted by eclogitic diamonds that suggest that sulfur involved in Archean atmospheric processes has been transferred to the mantle. Thus, the wide range of $\delta^{34} \mathrm{~S}$ and $\delta^{13} \mathrm{C}$ values associated with eclogitic diamonds attests to the inefficiency of mixing processes within the mantle.

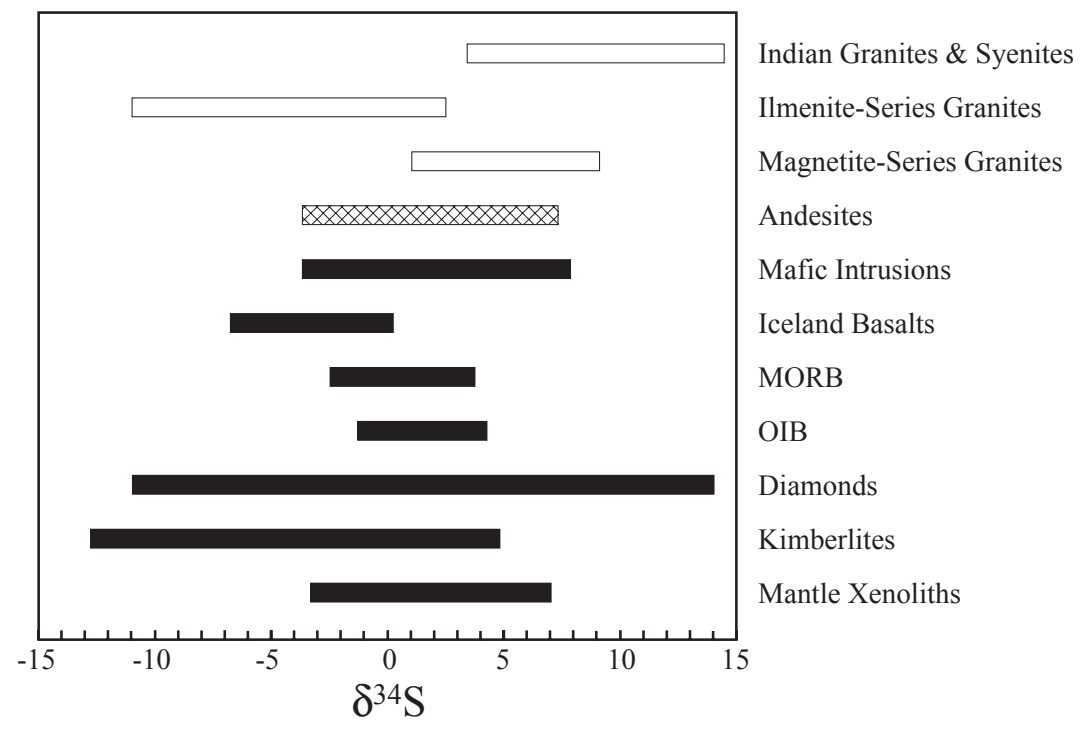

Figure 13. Range of $\delta^{34} S$ values for sulfides from mantle and oceanic and continental igneous settings. See text for sources of data. Isotopic values are given in permil (VCDT). 
The sulfur isotope variability found in all igneous rocks, from the most primitive to the most evolved, appears to reflect the global sulfur cycle as moderated by oxidation reactions because of the development of an oxygenated atmosphere, and reduction reactions because of bacterial activity. The sulfur isotope compositions of continental and island arc basalts and gabbros $\left(\delta^{34} \mathrm{~S}=1.0 \pm 3.2 \%\right.$ o $)$ are virtually indistinguishable from those from MORB and OIB (Fig. 13; Ueda and Sakai 1984; Chaussidon et al. 1987). In contrast, andesites have slightly higher $\delta^{34} \mathrm{~S}$ values $(2.6 \pm 2.3 \%$; Rye et al. 1984; Luhr and Logan 2002). Granitoid rocks have an average $\delta^{34} \mathrm{~S}$ value of $1.0 \pm 6.1 \%$, but range from -11 to $14.5 \%$, which presumably reflects variable assimilation or partial melting of either pyritic sedimentary rocks with low $\delta^{34} \mathrm{~S}$ values, or evaporites with high $\delta^{34}$ S values (Sasaki and Ishihara 1979; Ishihara and Sasaki 1989; Santosh and Masuda 1991). Ishihara and Sasaki (1989) found that ilmenite-series granitoids, generally regarded as having formed through partial melting of dominantly sedimentary protoliths, had sulfide $\delta^{34} \mathrm{~S}$ values less than $0 \%$, whereas magnetite-series granitoids thought to originate from dominantly igneous protoliths had $\delta^{34} \mathrm{~S}$ values greater than $0 \%$ (Fig. 13).

\section{Magmatic sulfide deposits}

Magmatic sulfide deposits are generally regarded to be those deposits that form as the result of magmatic crystallization processes, typically prior to saturation with respect to an aqueous phase. This summary focuses on magmatic $\mathrm{Ni}-\mathrm{Cu}$ and related deposits associated with mafic magmas, which generally formed as immiscible sulfide liquids during the crystallization of a mafic melt. These deposits are important resources for $\mathrm{Ni}, \mathrm{Cu}$, and platinum-group elements (PGE). Magmatic sulfide ore-forming systems can be divided into sulfur-poor and sulfur-rich end members where the sulfur-poor systems are the more important sources of PGE and the sulfur-rich systems are the more important sources of $\mathrm{Ni}$ and $\mathrm{Cu}$ (Ripley and Li 2003). Examples discussed in this section include the Duluth Complex (Minnesota), the Stillwater Complex (Montana), the Bushveld Complex (South Africa), Sudbury (Ontario), Voisey's Bay (Labrador), and Noril'sk (Russia). General aspects of sulfur geochemistry and specific aspects of sulfur isotope geochemistry associated with magmatic sulfide deposits have been reviewed by Ohmoto (1986) and more recently Ripley and Li (2003); their research forms the basis of the following discussion. Ripley and $\mathrm{Li}$ (2003) described hypothetical mixing relationships for sulfur isotopes and various metals between mantle-derived magmas and country rocks in the context of magmatic sulfide deposits.

Sulfur isotope data from sulfide minerals are a powerful tool for identifying sulfur contamination of the magma through interactions with the country rocks, if the sulfur isotopic composition of the country rocks was significantly different from the magma. In sulfur-poor systems, such as the Merensky Reef of the Bushveld Complex and the J-M Reef of the Stillwater Complex, in which sulfur requirements were more easily accommodated by solubility of sulfur in mafic magmas, the $\delta^{34} \mathrm{~S}$ values of sulfide minerals have a limited range and cluster around mantle values (i.e., 0\%o; Fig. 14) (Buchanan et al. 1981; Zientek and Ripley 1990; Ripley and Li 2003). In contrast, in sulfur-rich systems, such as the Duluth Complex and Noril'sk, the $\delta^{34} \mathrm{~S}$ values have a wide range and are significantly positive, suggesting contamination by crustal sources (Fig. 14; Ripley and Al-Jassar 1987; Li et al. 2003; Ripley et al. 2003).

The ability of sulfur isotopes to fingerprint crustal contamination of magmas associated with magmatic sulfide deposits depends upon the isotopic composition of the country rocks. In high-sulfur systems such as Sudbury and Voisey's Bay, the $\delta^{34} \mathrm{~S}$ values of sulfide minerals have a limited range of near mantle values (Thode et al. 1962; Schwarcz 1973; Ripley et al. 1999; Ripley et al. 2002; Fig. 14). At Sudbury, the $\delta^{34} \mathrm{~S}$ values of Archean metasedimentary rocks in the footwall of the deposits are near zero (Thode et al. 1962), making sulfur isotope evidence of crustal contamination of the magma equivocal at best. However, Schwarcz (1973) noted small, but discernable differences in the mean $\delta^{34} S$ values of magmatic sulfide deposits near Sudbury. He also documented a general decrease in the $\delta^{34} \mathrm{~S}$ values of the ore bodies moving 


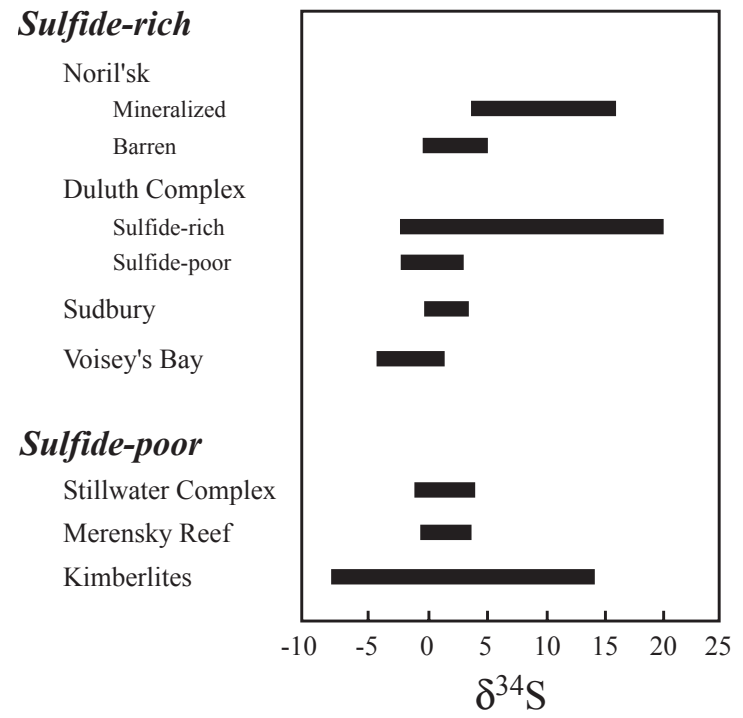

Figure 14. Range of $\delta^{34} \mathrm{~S}$ values for sulfides from magmatic sulfide deposits (modified from Ripley and Li 2003). Note greater range for sulfide-rich deposits, suggesting crustal contamination of magmas. See text for sources of data. Isotopic values are given in permil (VCDT).

from the country rocks to the intrusion, which supports the idea of crustal contamination of the magma. At Voisey's Bay, Ripley et al. (1999) found that the country rocks had a wide range of $\delta^{34} S$ values, but averaged near zero. Like Schwarcz (1973), in the Sudbury camp they also noted small variations in the isotopic composition of various mineralized zones. With a combination of sulfur, oxygen, and carbon isotope data and Se/S ratios from sulfides, Ripley et al. $(1999,2002)$ were able to define the role of crustal contamination at Voisey's Bay.

\section{Porphyry and epithermal deposits}

Porphyry deposits. Porphyry deposits formed from hydrothermal fluids exsolved from granitic magmas as they cooled with variable involvement of meteoric waters. They typically are large tonnage, low grade deposits. The different classes of porphyry deposits are important sources of $\mathrm{Cu}, \mathrm{Mo}, \mathrm{W}, \mathrm{Sn}$, and $\mathrm{Au}$, as well as other elements. From the perspective of the sulfur isotope composition of sulfide minerals, more significant and interesting isotopic variations can be found in magmatic hydrothermal systems having higher oxidation states, lower $\mathrm{pH}$ values, or both, as opposed to near-neutral or more reducing systems. Hydrothermal systems associated with more oxidized magmas, such as I-type granitoids, generally show more sulfur isotopic variations because $\mathrm{SO}_{2}$ and $\mathrm{H}_{2} \mathrm{~S}$ are present in the fluids in subequal proportions as opposed to those associated with $\mathrm{S}$-type granitoids which are dominated by $\mathrm{H}_{2} \mathrm{~S}$ (Burnham and Ohmoto 1980). Crustal contamination of the magmas, as discussed for magmatic sulfide deposits, can also affect the sulfur isotopic composition of magmatic hydrothermal systems. The sulfur isotope geochemistry of magmatic hydrothermal systems have been reviewed by Ohmoto (1986), Rye (1993), Seal et al. (2000a) and, most recently, by Rye (2005).

In high-temperature magmatic hydrothermal settings, such as those for porphyry copper deposits, many of the important processes contributing to sulfur isotope variations of sulfide minerals can be illustrated on diagrams showing the $\delta^{34} \mathrm{~S}$ of coexisting sulfide and sulfate minerals (Fifarek and Rye 2005; Rye 2005). These diagrams can provide information about the temperature of hydrothermal activity and the $\mathrm{SO}_{4}{ }^{2-} / \mathrm{H}_{2} \mathrm{~S}$ ratio of the fluid provided that: (1) the $\mathrm{SO}_{4}{ }^{2-} / \mathrm{H}_{2} \mathrm{~S}$ ratio of the fluid remained constant; (2) the bulk sulfur isotopic composition of the fluid $\left(\delta^{34} \mathrm{~S} \Sigma \mathrm{S}\right)$ remained constant, and (3) the only cause of isotopic variations in the initial $\delta^{34} \mathrm{~S}$ of the fluid was exchange between $\mathrm{SO}_{4}{ }^{2-}$ and $\mathrm{H}_{2} \mathrm{~S}$ in the fluid. Pairs of coexisting sulfate and 
sulfide minerals should fall along linear arrays having negative slopes ranging from vertical to horizontal, the slope being defined by the $\mathrm{SO}_{4}{ }^{2-} / \mathrm{H}_{2} \mathrm{~S}$ ratio of the fluid (Fig. 15). The line intersects the line corresponding to zero sulfur isotope fractionation between $\mathrm{SO}_{4}{ }^{2-}$ and $\mathrm{H}_{2} \mathrm{~S}$ at the bulk isotopic composition of the system $\left(\delta^{34} \mathrm{~S} \Sigma \mathrm{S}\right.$; Fig. 15). Isotherms plot as lines having positive slopes of unity, the lower temperatures falling down and to the right. When $\delta^{34} S_{\text {sulfide }}$ is plotted along the ordinate and $\delta^{34} \mathrm{~S}_{\text {sulfate }}$ plotted along the abscissa, a fluid having $\mathrm{H}_{2} \mathrm{~S}$ as the only sulfur species would plot as a horizontal line and a fluid with $\mathrm{SO}_{4}{ }^{2-}$ as the only sulfur species would plot as a vertical line. These lines represent limiting conditions for hydrothermal fluids; a line with a slope of -1 would have equal proportions of $\mathrm{SO}_{4}{ }^{2-}$ and $\mathrm{H}_{2} \mathrm{~S}\left(\mathrm{SO}_{4} / \mathrm{H}_{2} \mathrm{~S}=1\right)$. Natural settings seldom satisfy all of the conditions described above. Interpretation of natural data sets can be complicated by fluctuating fluid compositions, kinetic processes related to isotopic exchange and precipitation, and mixing of multiple sulfur reservoirs, among other processes (Shelton and Rye 1982; Ohmoto 1986; Krouse et al. 1990).

The isotopic characteristics of sulfate and sulfide minerals from porphyry environments suggest a general approach to equilibrium at elevated temperatures. Data from El Salvador, Chile (Field and Gustafson 1976), Gaspé, Quebec (Shelton and Rye 1982), Papua New Guinea (Eastoe 1983), and Butte, Montana (Field et al. 2005) are plotted in Figure 16. In general, the paired data plotted in Figure 16 suggest that equilibrium conditions were approximated by these hydrothermal systems. Collectively, the data suggest that the bulk sulfur isotope composition $\left(\delta^{34} \mathrm{~S} \Sigma \mathrm{S}\right)$ of porphyry copper hydrothermal systems typically ranges between 1 and $8 \%$, and that the inferred temperature is between 315 and $730{ }^{\circ} \mathrm{C}$, consistent with

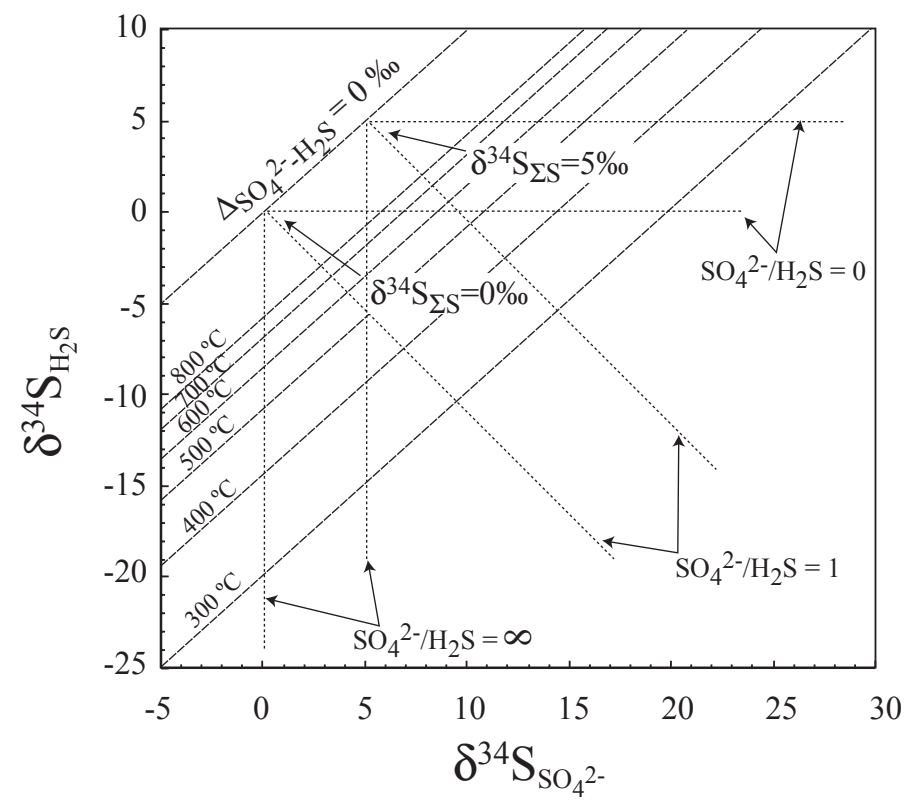

Figure 15. Theoretical aspects of equilibrium fractionation of sulfur isotopes between sulfide and sulfate in hydrothermal systems. Genetically related samples should define linear arrays due to cooling. These arrays should project back to the $0 \%$ o fractionation line at the bulk isotopic composition of the system as represented by the dotted lines. The slope of the dotted lines reflects the $\mathrm{SO}_{4}{ }^{2-} / \mathrm{H}_{2} \mathrm{~S}$ ratio of the hydrothermal fluid. The range of slopes is limited by a horizontal line indicating all $\mathrm{H}_{2} \mathrm{~S}$ and no $\mathrm{SO}_{4}{ }^{2-}$, and a vertical line indicating all $\mathrm{SO}_{4}{ }^{2-}$ and no $\mathrm{H}_{2} \mathrm{~S}$; a line with a slope of unity indicates equal proportions of $\mathrm{H}_{2} \mathrm{~S}_{\text {and }} \mathrm{SO}_{4}{ }^{2-}$ (modified from Rye 2005). Isotopic values are given in permil (VCDT). 


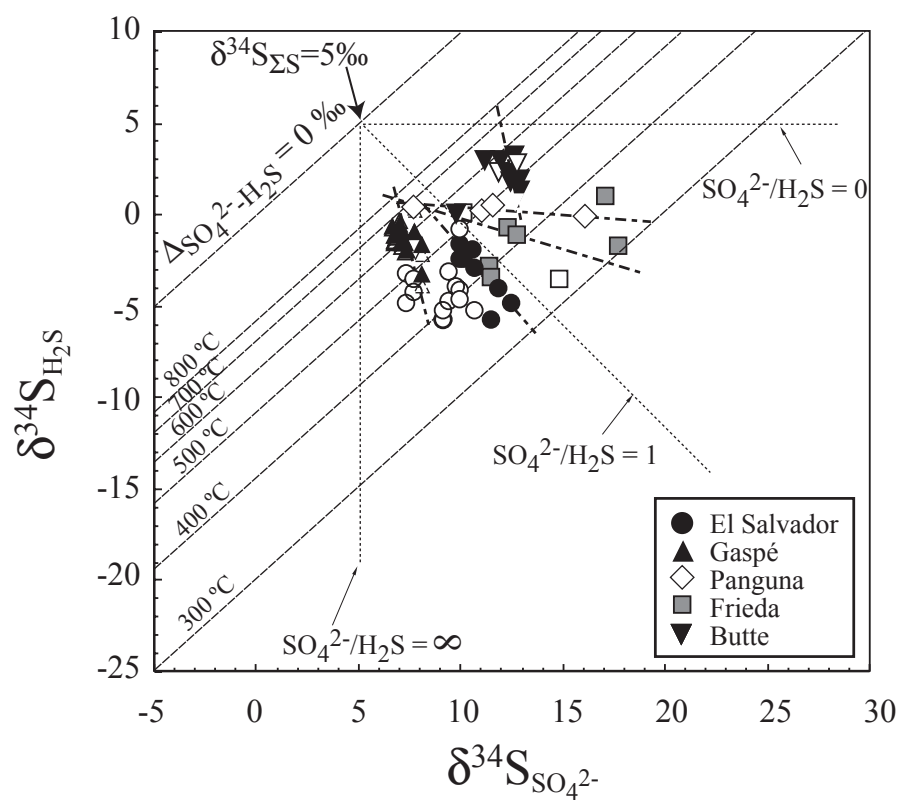

Figure 16. Plot of $\delta^{34} \mathrm{~S}$ of sulfide versus sulfate for porphyry hydrothermal systems (modified from Rye 2005). The different shapes of symbols are for different deposits. The shading of the symbols is for different sulfide minerals: black and gray, pyrite; white, chalcopyrite. See text for sources of data. Short dashed lines are regressed to the data from individual deposits by Rye (2005). Isotopic values are given in permil (VCDT).

temperature estimates from porphyry copper deposits based on other techniques such as fluid inclusions (Rye 2005). The trends in $\delta^{34} S_{\text {sulfide }}$ and $\delta^{34} S_{\text {sulfate }}$ in Figure 16 also suggest that porphyry copper hydrothermal systems have a range of oxidation states. Gaspé is one of the more sulfate-rich systems, and Panguna is one of the more sulfide-rich systems.

Many of the data from individual deposits define linear arrays, but some do not. Rye (2005) noted that the linearity of the data varies from mineral to mineral. For example at El Salvador the pyrite-anhydrite pairs define a line having a slope near unity, but the chalcopyriteanhydrite pairs do not (Fig. 16). This lack of correlation for the chalcopyrite data suggests that chalcopyrite is more prone to retrograde re-equilibration than pyrite, which is consistent with the known reactivities of these two sulfide minerals (Barton and Skinner 1979).

The interpretation of paired sulfide and sulfate data can include additional challenges, Eastoe (1983) questioned the equation of bulk fluid compositions with the composition of magmatic sulfur because of the complexities in the evolution of volatile phases from magmas. In high temperature porphyry environments, Shelton and Rye (1982) suggested that the discrepancies between fluid inclusion temperatures and sulfate-sulfide sulfur isotope temperatures may have resulted from the short time span between the disproportionation of $\mathrm{SO}_{2}$ to $\mathrm{SO}_{4}{ }^{2-}$ and $\mathrm{H}_{2} \mathrm{~S}$, and the subsequent precipitation of sulfate as anhydrite.

Epithermal deposits. Epithermal deposits are hydrothermal mineral deposits that form at shallow levels in the Earth's crust. They form from magmatic water, meteoric water, or mixtures of the two. Epithermal deposits can be divided into two types: acid-sulfate, and adularia-sericite types (Heald et al. 1987). Of these two types, acid-sulfate deposits tend to have more variation in the sulfur isotope composition of sulfide minerals because of the 
presence of significant quantities of both sulfide and sulfate in the hydrothermal fluids at the time of mineralization. Data for sulfide-sulfate mineral pairs from adularia-sericite type deposits are limited. Accordingly, the following discussion will focus primarily on acid-sulfate deposits. The stable isotope geochemistry of acid-sulfate deposits has been discussed by Rye et al. (1992) and Rye (2005).

Common aspects of the sulfur geochemistry of epithermal deposits can be identified using sulfur isotope data from pairs of sulfide and sulfate minerals. Paired sulfur isotope data from acid-sulfate epithermal deposits are available from Julcani, Peru (Rye et al. 1992), Rodalquilar, Spain (Arribas et al. 1995), Summitville, Colorado (Bethke et al. 2005), Pierina, Peru (Fifarek and Rye 2005), and Tapajós, Brazil (Juliani et al. 2005). In addition, a single pair from the Sunnyside, Colorado adularia-sericite type deposit is available (Casadevall and Ohmoto 1977). Sulfide minerals for which data are available include pyrite, pyrrhotite, and chalcopyrite; sulfate minerals include anhydrite, barite, alunite, and sulfate-bearing apatite. Figure 17 shows the $\delta^{34} \mathrm{~S}_{\text {sulfide }}$ and $\delta^{34} \mathrm{~S}_{\text {sulfate }}$ values for these deposits. Compared to porphyry copper deposits, the mineral pairs from epithermal deposits have a wider range of compositions, which reflects the generally lower temperatures of precipitation. With the exception of the deposits for which data are available from phenocrystic apatite (i.e., Summitville and Julcani), the data tend not to define linear trends. Nevertheless, the range of values is consistent with hydrothermal temperatures determined by other methods such as fluid inclusions, and suggest that the compositions record equilibrium conditions. Thus, the lack of linear trends for data from a given deposit may result from open-system behavior (i.e., boiling), which can alter the bulk composition of the hydrothermal fluid. Acid-sulfate epithermal deposits form at shallow levels in the Earth's crust. Many are thought to be the apical parts of porphyry copper hydrothermal systems (e.g., Lepanto, Philippines; Hedenquist et al. 1998).

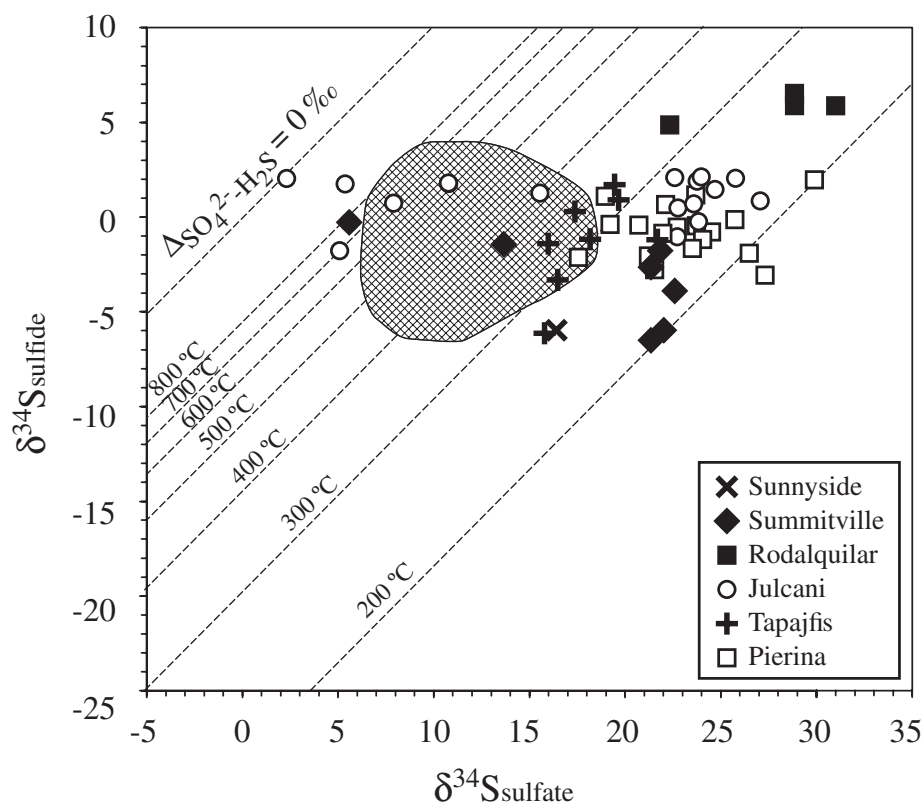

Figure 17. Plot of $\delta^{34} S$ of sulfide versus sulfate for epithermal hydrothermal systems. See text for sources of data. The shaded field encompasses the data from porphyry deposits depicted in Figure 16 for comparison. Note that the data from epithermal deposits imply lower temperatures than those for porphyry deposits, consistent with their inferred genetic relationships to intrusions. Isotopic values are given in permil (VCDT). 


\section{Seafloor hydrothermal systems}

Modern systems. The stable isotope characteristics of modern seafloor hydrothermal systems from mid-ocean ridges have been summarized recently by Shanks et al. (1995), Herzig et al. (1998), Seal et al. (2000a), and Shanks (2001). Sulfur isotope data are available for a variety of sulfide minerals from seafloor hydrothermal systems including pyrite, marcasite, pyrrhotite, chalcopyrite, bornite, cubanite, sphalerite and wurtzite, in addition to vent fluid $\mathrm{H}_{2} \mathrm{~S}$. A summary of the range of $\delta^{34} \mathrm{~S}$ values from various vent systems is present in Figure 18.

Igneous activity along submarine spreading centers causes hydrothermal convection that instigates a series of geochemical processes defining the sulfur cycle of these settings. In mid-ocean ridge hydrothermal systems, sulfide can be derived from three main sources: (1) leaching from country rocks, both igneous and sedimentary; (2) thermochemical reduction of seawater sulfate due to interaction with ferrous silicates and oxides, or with organic matter; and (3) leaching of sulfide minerals in sediments that were produced by bacterial sulfate reduction. Each of these sources has distinctive sulfur isotope signatures. Mid-ocean ridge basalts have sulfate/sulfide ratios (mass basis) ranging from 0.05 to 0.45 that correlate positively with the water content of the basalts (Sakai et al. 1984). The bulk sulfur isotopic composition averages $0.3 \pm 0.5 \%$, and the average $\delta^{34} S$ of the sulfide fraction is $-0.7 \pm 0.8 \%$ o (Sakai et al. 1984). Sulfate is stripped from seawater by the precipitation of sulfate minerals during heating associated with downwelling because of the retrograde solubility of anhydrite and other sulfate minerals (Bischoff and Seyfried 1978; Seyfried and Bischoff 1981; Shanks et al. 1995). Shanks et al. (1981) and Woodruff and Shanks (1988) proposed that most of the $\mathrm{H}_{2} \mathrm{~S}$ in vent fluids is derived from monosulfide solid solution. Because pyrite is the main sulfide

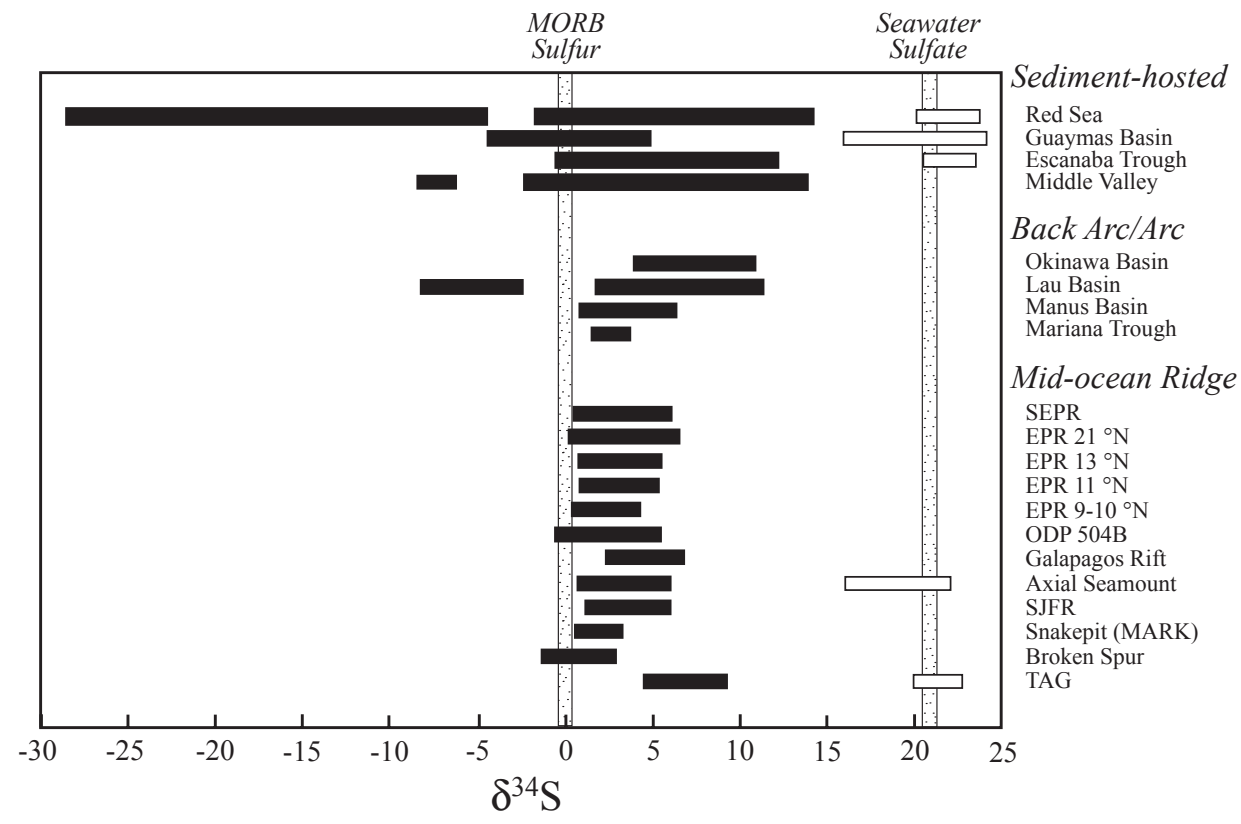

Figure 18. Range of $\delta^{34} \mathrm{~S}$ values for sulfide and sulfate minerals from modern seafloor hydrothermal systems. Modified from Shanks et al. (1995), Herzig et al. (1998), and Shanks (2001). Note limited variations from largely barren mid-ocean ridge systems and wide variations from sedimented systems where biogenic sulfide may be an important component. Isotopic values are given in permil (VCDT). 
mineral in altered oceanic crust, the derivation of $\mathrm{H}_{2} \mathrm{~S}$ from monosulfide solid solution would require an oxidation step as described by the reaction:

$$
8 \mathrm{FeS}+10 \mathrm{H}^{+}+\mathrm{SO}_{4}{ }^{2-} \rightarrow 4 \mathrm{FeS}_{2}+\mathrm{H}_{2} \mathrm{~S}+4 \mathrm{H}_{2} \mathrm{O}+4 \mathrm{Fe}^{2+}
$$

which should release $\mathrm{H}_{2} \mathrm{~S}$ with a $\delta^{34} \mathrm{~S}$ of 1 to $1.5 \%$ (Woodruff and Shanks 1988).

The isotopic effects associated with seawater-basalt interactions and associated hydrothermal activity have been modeled by Janecky and Shanks (1988) as two end-member processes: simple adiabatic mixing, and shallow thermochemical reduction. They concluded that simple adiabatic mixing can produce $\mathrm{H}_{2} \mathrm{~S}$ having a maximum $\delta^{34} \mathrm{~S}$ of $4.5 \%$ o. They also found that thermochemical reduction of seawater sulfate through interactions with ferrous silicates or oxides is more likely to be important at moderate temperature, off-axis settings where the retrograde solubility of sulfate minerals has not removed as much sulfate as in higher temperature settings. Shanks et al. (1981) demonstrated experimentally the effectiveness of sulfate reduction through interactions with olivine and magnetite. According to the model of Janecky and Shanks (1988), thermochemical reduction of modern seawater sulfate through interactions with magnetite can generate $\mathrm{H}_{2} \mathrm{~S}$ having a $\delta^{34} \mathrm{~S}$ as high as $15 \%$ o. In contrast, hydrogen sulfide derived from the dissolution of biogenic sulfides in sedimentary rocks would be expected to have negative $\delta^{34} \mathrm{~S}$ values reflecting bacterial sulfate reduction, as described above.

Modern seafloor hydrothermal sulfide minerals and vent fluids reflect the combination of the processes of simple adiabatic mixing, thermochemical reduction, and dissolution of biogenic sulfide minerals. Mid-ocean ridge systems, largely barren of sediments, have $\delta^{34} \mathrm{~S}$ values that typically range between 0 and $6 \%$, with the exception of the TAG field along the Mid-Atlantic Ridge (Fig. 18). Compared to the other examples, TAG is a slow-spreading center, which includes a greater component of shallow seawater entrainment, sub-seafloor hydrothermal mineral precipitation and basalt alteration, compared to fast-spreading centers. These processes are more conducive to thermochemical reduction of seawater sulfate, which imparts higher $\delta^{34} \mathrm{~S}$ values to the resulting sulfide. Sedimented systems have a greater range to both higher and lower $\delta^{34} \mathrm{~S}$ values. The lower values undoubtedly document the remobilization of sulfide initially precipitated by bacterial sulfate reduction. The sulfur isotopic characteristics of backarc and arc settings are interesting because some negative $\delta^{34} \mathrm{~S}$ values have been documented at sites lacking significant sedimentary cover. These sites also have low $\mathrm{pH}$ fluids that exceed seawater concentrations of sulfate; disproportionation of $\mathrm{SO}_{2}$, as described by Equation (20), has been proposed to explain the low $\delta^{34} S$ values (Herzig et al. 1993; Gamo et al. 1997). In essence, these back-arc seafloor hydrothermal systems would represent the modern seafloor equivalents of the terrestrial acid-sulfate epithermal systems discussed above.

Another interesting aspect of the sulfur isotope characteristics of sulfides in seafloor hydrothermal systems is in the isotopic composition of the vent fluid $\mathrm{H}_{2} \mathrm{~S}$. Shanks (2001) described how the $\delta^{34} \mathrm{~S}$ of vent fluid $\mathrm{H}_{2} \mathrm{~S}$ is commonly $1 \%$ o to more than $4 \%$ o higher than that of sulfide minerals on the inner walls of hydrothermal chimneys. For most of the common sulfide minerals found in seafloor chimneys, the $\delta^{34} \mathrm{~S}$ of the mineral should be higher than that for the associated $\mathrm{H}_{2} \mathrm{~S}$, and in all cases the difference should be less than $1 \%$ at measured temperatures. Shanks (2001) suggested that local reduction of seawater sulfate in the chimney environment or equilibrium restricted to the minute, innermost layer of sulfide minerals may partially explain this discrepancy. An equally impressive observation on the sulfur isotopic composition of vent fluid $\mathrm{H}_{2} \mathrm{~S}$ is found in time-series sampling of individual vents on the scale of weeks, months, or a few years. Along the East Pacific Rise, the $\delta^{34} \mathrm{~S}$ of $\mathrm{H}_{2} \mathrm{~S}$ from the Aa vent was found to increase by approximately $2 \%$ over the course of approximately three years, whereas that of the $\mathrm{P}$ vent decreased by over $3 \%$ over a similar period.

Ancient systems. The sulfur isotope compositions of sulfide minerals from ancient seafloor massive sulfide deposits are interpreted in terms of the same geochemical processes as 
operative in modern systems, but with a few additional complexities. Secular variations in the sulfur isotope composition of seawater, discussed previously, result in one potential component of sulfide sulfur having a composition that varies as a function of time. A second complexity is the periodic occurrence of anoxic bottom waters in the oceans on a global scale (Leggett 1980), which can result in the presence of $\mathrm{H}_{2} \mathrm{~S}$ in the water column near the seafloor. The following discussion focuses on two general classes of ancient seafloor deposits containing sulfide minerals: volcanic-associated (volcanogenic) massive sulfide deposits, and sedimentary-exhalative (sedex) massive sulfide deposits. Ohmoto (1986) and Huston (1999) have provided reviews of the stable isotope characteristics of ancient volcanic-associated massive sulfide deposits; Seal et al. (2000a) reviewed their isotopic characteristics from the perspective of their associated sulfate minerals.

Volcanic-associated deposits form at active mid-ocean ridge spreading centers, and in arc-volcanic rocks, continental rifts, and Archean greenstone belts, whereas sedex deposits form in failed continental rift settings. Volcanic-associated and sedex deposits are dominated by sulfide minerals, most commonly pyrite, pyrrhotite, chalcopyrite, sphalerite, and galena in varying proportions. They can also have associated sulfate minerals, typically anhydrite, barite, or gypsum. These deposits are major sources of $\mathrm{Cu}$, $\mathrm{Pb}, \mathrm{Zn}, \mathrm{Ag}$, and $\mathrm{Au}$.

The secular variations observed in the sulfur isotopic composition of sulfide and sulfate minerals in seafloor massive sulfide deposits mimic, to a remarkable degree, the secular variations observed in sedimentary pyrite and marine sulfate and attest to the dominant role that atmospheric oxygen has on the global sulfur cycle (Huston 1999; Figs. 9 and 19). The compilation of Huston (1999) has been expanded to include data from sedimentary exhalative deposits and additional volcanicassociated deposits in Figure 19. The $\delta^{34} \mathrm{~S}$ values of sphalerite, galena and pyrite from the Mississippian Red Dog deposit, Alaska, range from -45.8 to $12.3 \%$ o, with most values between -2.5 and $7.5 \%$ o (Kelley et al. 2004). The lowest values were produced during the earliest stages

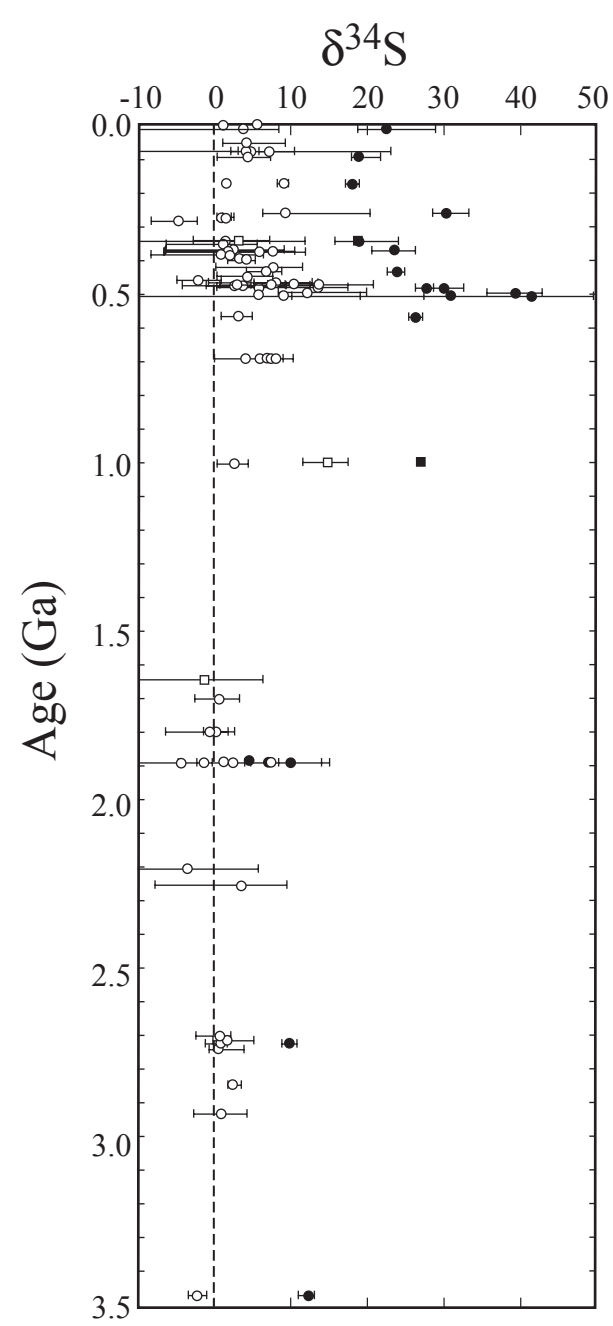

Figure 19. Secular variation of the isotopic composition of sulfide and sulfate minerals from seafloor massive sulfide deposits. Modified from Huston (1999) with data from Whelan et al. (1984), Seal and Wandless (2003), Seal et al. (2000b, 2001), and Kelley et al. (2004). Volcanic-associated deposits are shown by circles; sedimentary exhalative deposits are shown by squares. Sulfides are white symbols; sulfates are black symbols. Isotopic values are given in permil (VCDT). 
of hydrothermal activity. Similarly, the $\delta^{34} \mathrm{~S}$ values of pyrrhotite, pyrite, sphalerite, and galena from the Proterozoic Sullivan and nearby deposits, in the Purcell Supergroup, British Columbia, range between -11 and $6 \%$ o having a distinct mode around $-1 \%$ o (Seal et al. 2000b; Taylor and Beaudoin 2000). Taylor and Beaudoin (2000) found significant stratigraphic variations in the $\delta^{34} \mathrm{~S}$ values of sulfide minerals within the deposit, which they interpreted in terms of variations in the relative proportions of $\mathrm{H}_{2} \mathrm{~S}$-derived bacterial sulfate reduction and thermochemical sulfate reduction throughout the period of hydrothermal activity. The Proterozoic Balmat-Edwards $\mathrm{Zn}-\mathrm{Pb}$ deposits, which experienced amphibolite-facies regional metamorphism, have a limited range of $\delta^{34} \mathrm{~S}$ values from pyrite, sphalerite, and galena (11.5 to $17.5 \%$ o), presumably because of the homogenizing effects of the metamorphism (Whelan et al. 1984).

Prior to $2.4 \mathrm{Ga}$, the inferred onset of oxygen in the atmosphere, the $\delta^{34} \mathrm{~S}$ of hydrothermal sulfide and sulfate indicated limited variations and both cluster near $0 \%$ o. Between 2.4 and 0.7 $\mathrm{Ga}$, the $\delta^{34} \mathrm{~S}$ of hydrothermal sulfide and sulfate has a significantly wider range and increasing $\delta^{34} \mathrm{~S}$ values. Beginning after $0.7 \mathrm{Ga}$, the time proposed by Canfield and Teske (1996) for the onset of higher oxygen levels in the atmosphere, the $\delta^{34} \mathrm{~S}$ of hydrothermal sulfides and sulfates indicates a dramatic increase both in range and average value (Fig. 19).

The general correlation between the average $\delta^{34} \mathrm{~S}$ of a volcanic-associated massive sulfide deposit and coeval seawater was first identified by Sangster (1968). He noted a roughly $17.5 \%$ difference between seawater and the mean composition of volcanic-associated massive sulfide deposits. For sediment-hosted deposits, which include sedimentary-exhalative deposits among other types, he found a smaller $11.7 \%$ o fractionation between seawater and sulfide. Janecky and Shanks (1988) quantified the relationship between the $\delta^{34} S$ of coeval seawater and sulfide in basaltic seafloor hydrothermal systems using reaction-path geochemical modeling coupled with sulfur-isotope mass-balance equations. They found that for simple adiabatic mixing, as discussed above, the maximum $\delta^{34} \mathrm{~S}$ of sulfides that can be achieved is $4.5 \%$, which corresponds to a seawater-sulfide fractionation of $16.5 \%$, remarkably similar to the fractionation proposed by Sangster (1968). Janecky and Shanks (1988) found a maximum $\delta^{34} \mathrm{~S}$ of sulfides formed through thermochemical reduction of $15 \%$, which corresponds to a seawater-sulfide fractionation of $6 \%$. These maximum compositions of sulfide resulting from these two end-member processes will vary accordingly with secular variations in the $\delta^{34} S$ of seawater sulfate. Despite the predictable relationship between the $\delta^{34} S$ of seawater and hydrothermal sulfides, Janecky and Shanks (1988) found that sulfur isotope disequilibrium best describes sulfide and sulfate in seafloor vent systems, and that the systematic relationship is established at depth in the reaction zone of the seafloor hydrothermal system.

Sulfur isotope studies in the Selwyn Basin (Yukon) by Goodfellow (1987) and Shanks et al. (1987) suggested the significance of $\mathrm{H}_{2} \mathrm{~S}$-bearing anoxic bottom waters in determining the isotopic composition of sedimentary-exhalative massive sulfide deposits. Goodfellow and Jonasson (1984) investigated the sulfur isotope composition of sedimentary pyrite and barite within the Cambrian to Mississippian strata of the Selwyn basin. They used the barite data to define a local Selwyn basin sulfate sulfur isotope secular curve that is locally over $20 \%$ o higher than the global marine sulfate curve of Claypool et al. (1980). They used the higher values within the Selwyn basin as evidence that the Selwyn basin had restricted access to the open ocean and that the bottom waters were anoxic and $\mathrm{H}_{2} \mathrm{~S}$-bearing. Shanks et al. (1987) extended the Selwyn basin curve farther back into Cambrian time with additional data from the Anvil district. They used data from sedimentary pyrite to define a secular $\mathrm{H}_{2} \mathrm{~S}$ curve. Goodfellow (1987) used the coincidence of the sulfur isotopic composition of the massive sulfide deposits with that of the sedimentary pyrites to conclude that sulfur for the mineral deposits was dominantly derived from $\mathrm{H}_{2} \mathrm{~S}$ in an anoxic water column during periods of stagnation in the Selwyn basin. He proposed that these stagnation events may have been global in extent. Goodfellow and Peter (1996) provided additional support for the global extent of these anoxia events from their studies of the sulfur isotope 
geochemistry of the Brunswick No. 12 deposit in the Bathurst mining camp (New Brunswick), which has sulfur isotope values that fall on the secular pyrite curve for the Selwyn basin.

The role of anoxic bottom waters for the genesis of volcanic-associated massive sulfide deposits can be evaluated by comparing the secular variations in the sulfur isotope composition of seawater and hypothetical hydrothermal sulfide with the sulfur isotope compositions of sulfide and sulfate minerals from massive sulfide deposits. Seal and Wandless (2003) compared secular variations in the sulfur isotopic composition of sulfide and sulfate minerals from Cambrian and Ordovician volcanic-associated massive sulfide deposits from around the world with the global marine sulfate curve, Selwyn basin pyrite curve, and the maximum $\delta^{34} S$ values attainable through simple adiabatic mixing and shallow thermochemical reduction (Fig. 20), as modeled by Janecky and Shanks (1988). Figure 20 has been extended into the latest Proterozoic to include data from the Barite Hill deposit, South Carolina for comparison (Seal et al. 2001). Seal and Wandless (2003) found that the sulfur isotope composition of many of the deposits fell within the permissible range for simple adiabatic mixing, and that all fell within the permissible range for shallow thermochemical reduction (Fig. 20). Thus, the isotopic characteristics of sulfide minerals from all of these deposits can be explained without the need for anoxic $\mathrm{H}_{2} \mathrm{~S}$-bearing bottom waters, although their role is not necessarily excluded. The $\delta^{34} \mathrm{~S}$ values of the associated sulfate minerals provide the most compelling evidence for anoxic waters in the case of the deposits of the Mount Read volcanic belt, Tasmania (Solomon et al. 1969, 1988; Gemmell and Large 1992; McGoldrick and Large 1992), which have $\delta^{34} \mathrm{~S}$ values for sulfate well in excess of the global marine sulfate curve (Fig. 20).

\section{Mississippi Valley-type deposits}

Mississippi Valley-type $\mathrm{Pb}-\mathrm{Zn}$ deposits typically form in continental settings in lowtemperature $\left(<200{ }^{\circ} \mathrm{C}\right)$, near-neutral environments in which sulfur isotope disequilibrium would be expected to dominate (Ohmoto and Lasaga 1982). Thus, stable isotope data from sulfide minerals from Mississippi Valley-type deposits should provide information about the source of sulfide and its geochemical history. Stable isotope studies of Mississippi Valley-type deposits are dominated by sulfur isotope data from both sulfide and sulfate minerals (Ault and Kulp 1960; Sasaki and Krouse 1969; Ohmoto 1986; Kaiser et al. 1987; Richardson et al. 1988; Kesler et al. 1994; Appold et al. 1995; Kesler 1996; Misra et al. 1996; Jones et al. 1996).

Sulfide sulfur in Mississippi Valley-type environments can be derived from a variety of sources including organically bound sulfur, $\mathrm{H}_{2} \mathrm{~S}$ reservoir gas, evaporites, connate seawater, and diagenetic sulfides. In all cases, these sources are seawater sulfate that has followed various geochemical pathways that impart different isotopic fractionations. The reduction of sulfate occurs either through bacterially mediated processes or abiotic thermochemical processes. Bacterial sulfate reduction, as discussed above, can produce sulfate-sulfide fractionations that typically range from 15 to 60\% (Goldhaber and Kaplan 1975), whereas those associated with abiotic thermochemical reactions with organic compounds range from zero to as much as $10 \%$ o (Orr 1974; Kiyosu 1980). Bacterial sulfate reduction has been documented at temperatures up to $110^{\circ} \mathrm{C}$ (Jørgensen et al. 1992), but the optimum temperature range is between 30 and $40^{\circ} \mathrm{C}$. Ohmoto and Goldhaber (1997) argued that at the site of ore deposition, thermochemical reduction is not effective at $T<125{ }^{\circ} \mathrm{C}$ because of slow reaction kinetics. For thermochemical reduction to be an important process in Mississippi Valley-type environments, reduction must occur away from the site of ore deposition, in the deeper, hotter parts of the basin. It should be noted that although the kinetic fractionations associated with both reduction processes are distinct, they can produce $\mathrm{H}_{2} \mathrm{~S}$ of similar compositions if bacterial sulfate reduction occurs quantitatively (or nearly so) in an environment with little or no Fe to sequester the sulfide.

Sulfur isotope data from other Mississippi Valley-type deposits suggest two major sulfide reservoirs, one centered between -5 to $15 \%$ and one greater than $20 \%$ (Fig. 21). The higher values of sulfides typically coincide with those of the composition of associated sulfate 


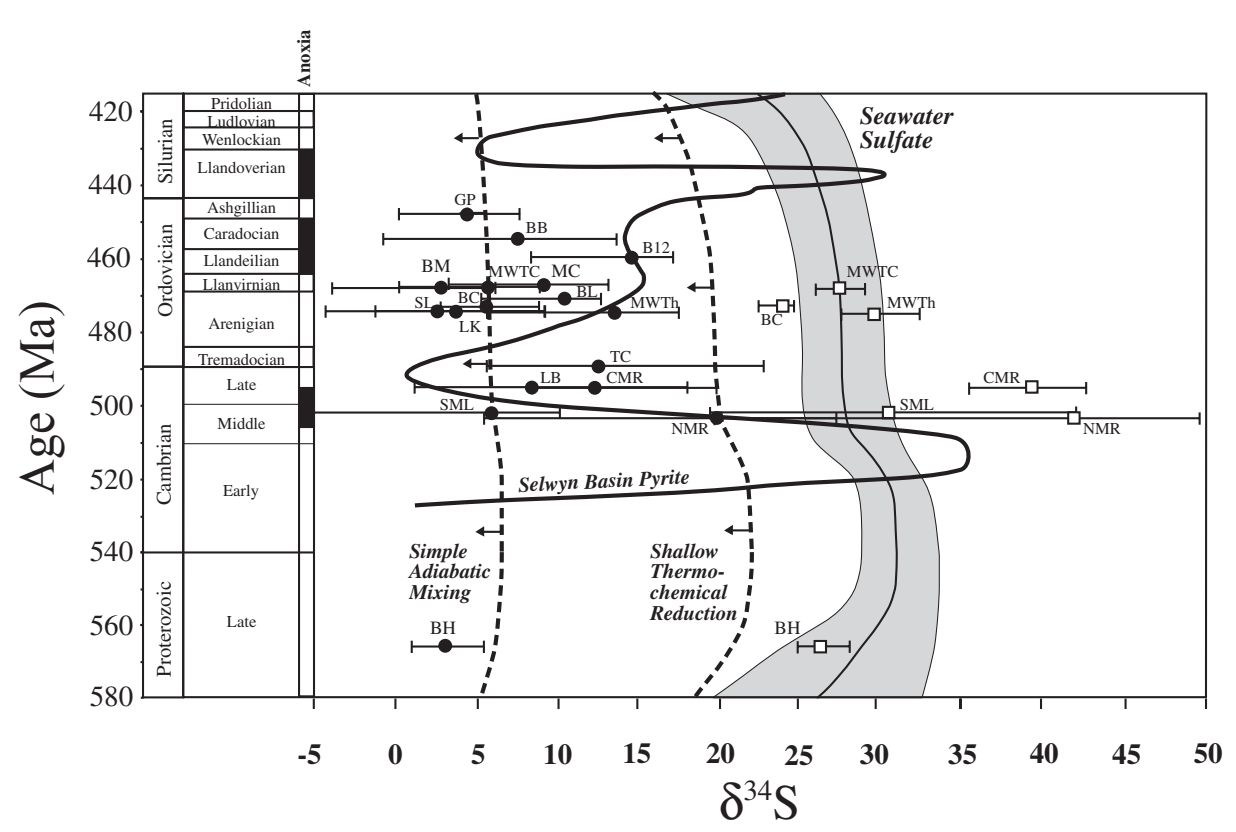

Figure 20. Variation of sulfur isotope composition with age for various Early Paleozoic and Late Proterozoic massive sulfide deposits (modified from Seal and Wandless 2003). The age distribution of anoxic events in the Iapetus Ocean indicated on the figure is reflected by the presence of black shales (after Leggett 1980). The compositions of the deposits are shown as the mean and range. Data are from Huston (1999) unless otherwise noted in text. The seawater sulfate curve (gray field) is modified from Claypool et al. (1980) to account for the $1.65 \%$ o fractionation between evaporitic sulfate minerals and dissolved sulfate (Seal et al. 2000). The Selwyn Basin pyrite curve (heavy black line) is modified from Goodfellow and Jonasson (1984). The upper limits for the composition of sulfide derived from simple adiabatic mixing of vent-fluid $\mathrm{H}_{2} \mathrm{~S}$ and ambient seawater and of sulfide derived from shallow level thermochemical reduction of seawater sulfate are based on the models of Janecky and Shanks (1988) and are shown as the dashed curves with arrows. Black circles depict data from sulfide minerals; white squares depict data from sulfate minerals. Abbreviations: B12, Brunswick No. 12, Bathurst Mining camp, New Brunswick; BB, Boucher Brook Formation deposits, Bathurst Mining Camp, New Brunswick; BC, Buchans, Newfoundland; BH, Barite Hill, South Carolina; BL, Balcooma, Queensland; CMR, Central Mount Read Volcanics Belt, Tasmania; GP, Gull Pond, Newfoundland; LB, Lush's Bight Ophiolite, Newfoundland; LK, Lokken Ophiolite, Norway; MWTC, Mount Windsor-Trooper Creek, Queensland; MWTh, Mount WindsorThalanga, Queensland; NMR, Northern Mount Read Volcanics Belt, Tasmania; SL, Sulitjelma, Norway; SML, Southern Mount Lyell Volcanics Belt, Tasmania TC, Tilt Cove, Newfoundland.

minerals, and have been interpreted to reflect the minimal fractionation associated with abiotic thermochemical reduction (Kesler 1996). However, similar compositions of sulfide could be generated by closed-system, quantitative bacterial reduction of sulfate. A carbonate aquifer is an ideal environment for such a geochemical process due to the lack of reactive Fe to scavenge and fractionate sulfur. The lower values may reflect formation from $\mathrm{H}_{2} \mathrm{~S}$ derived either directly or indirectly from open-system bacterial reduction of sulfate. Kesler et al. (1994) proposed that low $\delta^{34} \mathrm{~S}_{2} \mathrm{~S}$ was derived from oil in the deeper parts of the basin for the Central Tennessee and Kentucky Mississippi Valley-type districts. This $\mathrm{H}_{2} \mathrm{~S}$ ultimately would have been derived from the bacterial reduction of sulfate. The $\mathrm{H}_{2} \mathrm{~S}$ from both bacterial and abiotic reduction is not in sulfur isotope equilibrium with associated sulfate minerals (Fig. 21).

Stable isotope and fluid-inclusion studies by Richardson et al. (1988) of samples from the Deardorff mine from the Cave-in-Rock fluorspar district, Illinois, indicate mineralization was 


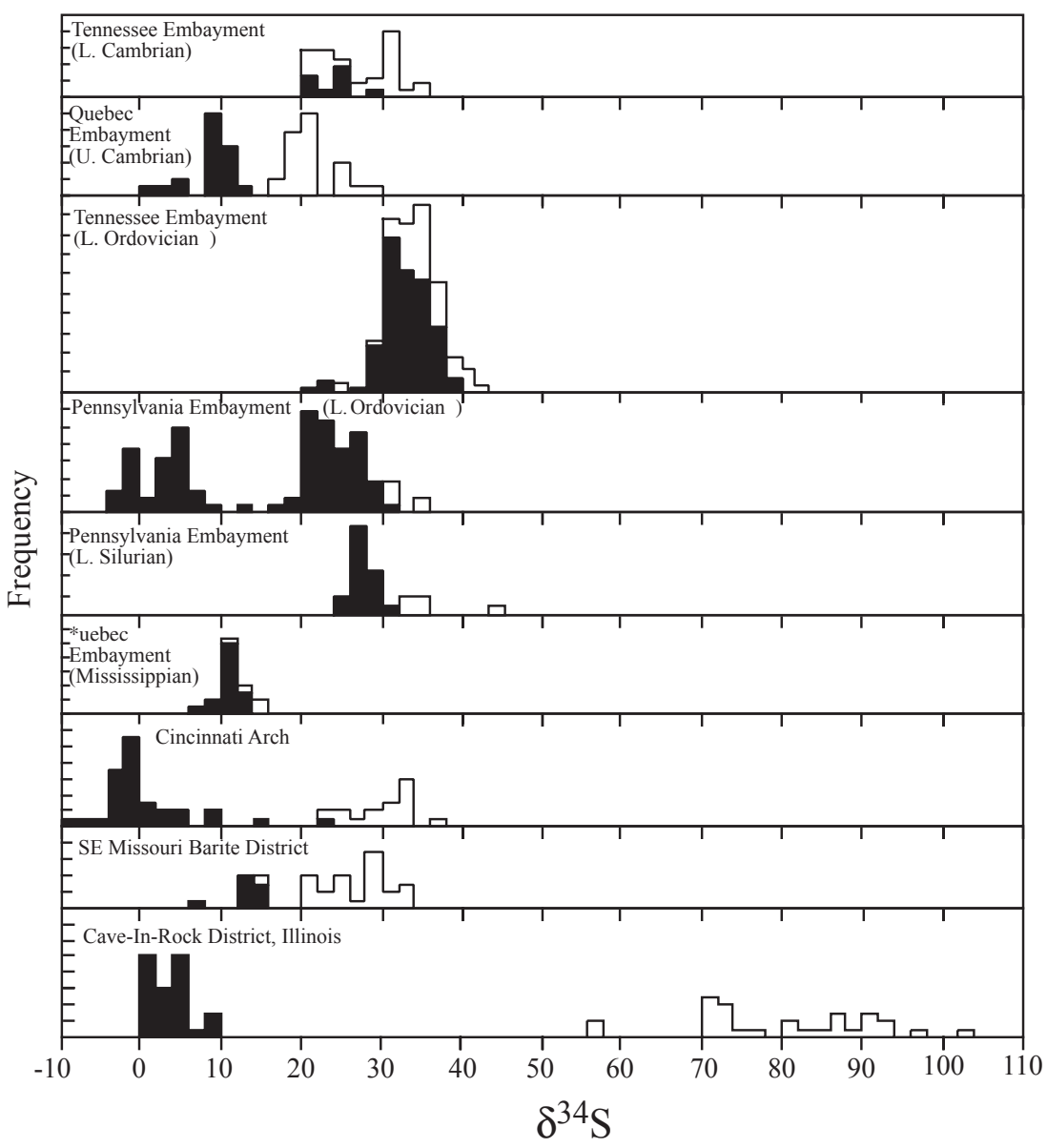

Figure 21. Sulfur isotope histograms for Mississippi Valley-type hydrothermal systems in North America. Data from sphalerite are shown in black; data from sulfate minerals are shown in white. All isotopic values are given in permil (VCDT).

dominated by two formation fluids recharged by meteoric waters, one of which circulated into the basement rocks under low water/rock conditions. Liquid hydrocarbons are present in fluid inclusion in most minerals. The low $\delta^{34} \mathrm{~S}$ of sulfides (4.0 to $8.9 \%$ o for sphalerite) indicates a significant contribution of $\mathrm{H}_{2} \mathrm{~S}$ from petroleum sources. The sulfides are completely out of isotopic equilibrium with late stage barites, which have $\delta^{34} S$ values ranging from about 57 to $103 \%$. These data suggest that the aqueous sulfate was derived from a small fluid reservoir in which the residual seawater sulfate underwent thermal chemical reduction with organic matter. Supporting evidence includes the decrease in the $\delta^{13} \mathrm{C}_{\mathrm{CO}_{2}}$ of the fluids during carbonate deposition.

\section{SUMMARY}

The Earth is assumed to have a bulk $\delta^{34} \mathrm{~S}$ value of around $0 \%$, essentially the same as most meteorites. Some of the most important factors affecting sulfur isotope fractionation throughout the history of the Earth have been oxidation and reduction reactions that ultimately 
have been facilitated by the progressive development of an oxygenated atmosphere. Prior to $2.4 \mathrm{Ga}$, the sedimentary record reveals limited variation in the $\delta^{34} \mathrm{~S}$ of sulfides and sulfates, presumably due to the lack of oxygen. The ancient geologic record also preserves significant mass-independent sulfur isotope anomalies which have been interpreted to be the result of UV-induced photochemical reactions in the atmosphere due to the absence of an ozone layer (Farquhar et al. 2000a). The mass-independent anomalies stop abruptly after $2.4 \mathrm{Ga}$ and the $\delta^{34} \mathrm{~S}$ of sedimentary sulfides and sulfates begin to show greater variability, consistent with the onset of an oxygenated atmosphere. Beginning at about $0.7 \mathrm{Ga}$, another major change in the variability of the $\delta^{34} \mathrm{~S}$ of sedimentary sulfides and sulfates occurs that is indicated by much wider ranges of compositions, which again has been interpreted in terms of increased atmospheric concentrations of oxygen (Canfield and Teske 1996). These same transitions in sedimentary isotopic compositions are also apparent in the isotopic signatures of marine, volcanic-associated massive sulfide deposits.

Throughout much of the history of the Earth, the metabolism of sulfate-reducing bacteria has been important in producing the variability recorded in the geologic record. The profound impact of sulfate-reducing bacteria on the global sulfur cycle may even be discernible in the mantle, where the negative $\delta^{34} \mathrm{~S}$ values of sulfide inclusions are likely derived from subducted sedimentary sulfides (Chaussidon et al. 1987; Eldridge et al. 1991). Equally impressive is the fact that these mantle heterogeneities may have persisted for billions of years as indicated by the identification of mass-independent anomalies in sulfide inclusions in diamonds, for which the most likely explanation is that the anomalies were locked in the mineral record prior to $2.4 \mathrm{Ga}$ when the atmosphere became oxygenated (Farquhar et al. 2002). The isotopic imprint of sulfate-reducing bacteria can be found in many reaches of the sulfur cycle, from sedimentary sulfides and sulfates, to coal beds, to seafloor hydrothermal mineral deposits, to continental Mississippi Valley-type deposits formed from basinal brines, and to magmas of all compositions that have interacted with crustal rocks.

Sulfur-rich magmatic sulfide deposits associated with mafic igneous rocks commonly record the fingerprint of contamination by crustal sedimentary sulfur. Hydrothermal systems associated with oxidized felsic magmas emplaced into shallow levels of the crust reflect sulfur isotope signatures determined by high-temperature isotopic exchange between reduced and oxidized sulfur species such as $\mathrm{H}_{2} \mathrm{~S}$ and $\mathrm{SO}_{4}{ }^{2-}$, which commonly are the result of the disproportionation of $\mathrm{SO}_{2}$. High-temperature settings associated with porphyry environments tend to record equilibrium sulfur isotope fractionations, whereas moderate temperature settings, such as those for epithermal deposits are more likely to record disequilibrium fractionations, unless the fluids are more acidic when the kinetics of sulfur isotope exchange are more favorable (Ohmoto and Lasaga 1982). In even lower temperature environments, such as those associated with diagenetic sulfides including coal beds, and basinal brines associated with Mississippi Valley-type deposits, kinetic fractionations dominate rather than equilibrium fractionations. In all cases, it is the reaction of a reduced sulfur species to an oxidized sulfur species, the reaction of an oxidized sulfur species to a reduced sulfur species, or isotopic exchange between an oxidized and a reduced sulfur species that causes the most significant sulfur isotope variations.

\section{ACKNOWLEDGMENTS}

Discussions with Bob Rye and Pat Shanks have been incredibly rewarding over the years. Don Canfield kindly shared his sulfur-isotope data base. Laboratory assistance and support from Greg Wandless has been indispensable. Assistance with literature searches from Carmen O'Neill and Nadine Piatak is greatly appreciated. Brenda Pierce assisted with Russian translations. The manuscript benefited from reviews by Avery Drake, Jeff Grossman, Nadine Piatak, Pat Shanks, 
and David Vaughan. The preparation of this chapter has been supported by Kate Johnson, Program Coordinator of the Mineral Resources Program of the U.S. Geological Survey.

\section{REFERENCES}

Albarède F (2004) The stable isotope geochemistry of copper and zinc. Rev Mineral Geochem 55:409-427

Anbar AD (2004) Molybdenum stable isotopes: observations, interpretations and directions. Rev Mineral Geochem 55:429-454

Appold MS, Kesler SE, Alt JC (1995) Sulfur isotope and fluid inclusion constraints on the genesis of Mississippi Valley-type mineralization in the Central Appalachians. Econ Geol 90:902-919

Arribas A Jr., Cunningham CG, Rytuba JJ, Rye RO, Kelly WC, Podwysocki MH, McKee EH, Tosdal RM (1995) Geology, geochronology, fluid inclusions, and isotope geochemistry of the Rodalquilar gold-alunite deposit, Spain. Econ Geol 90:795-822

Ault WU, Kulp JL (1960) Sulfur isotopes and ore deposits. Econ Geol 55:73-100

Ault WU, Jensen ML (1963) Summary of sulfur isotope standards. In: Biogeochemistry of Sulfur Isotopes. Jensen ML (ed) Nat Sci Found, Symp Proc, Yale University

Bachinski DJ (1969) Bond strength and sulfur isotopic fractionation in coexisting sulfides. Econ Geol 64:5665

Bahr JR (1976) Sulfur isotopic fractionation between $\mathrm{H}_{2} \mathrm{~S}, \mathrm{~S}$ and $\mathrm{SO}_{4}{ }^{2-}$ in aqueous solutions and possible mechanisms controlling isotopic equilibrium in natural systems. M.Sc. thesis, Pennsylvania State University

Barton PB Jr, Skinner BJ (1979) Sulfide mineral stabilities. In: Geochemistry of Hydrothermal Ore Deposits Barnes HL (ed) J Wiley and Sons, 278-403

Barling J, Arnold GL, Anbar AD (2001) Natural mass-dependent variations in the isotopic composition of molybdenum. Earth Planet Sci Lett 193:447-457

Beard BL, Johnson CM (2004) Fe isotope variations in the modern and ancient earth and other planetary bodies. Rev Mineral Geochem 55:319-357

Beaudoin G, Taylor BE (1994) high precision and spatial resolution sulfur isotope analysis using MILES laser microprobe. Geochim Cosmochim Acta 58:5055-5063

Bekker A, Holland HD, Wang P-L, Rumble D, III, Stein HJ, Hannah JL, Coetzee LL, Beukes NJ (2004) Dating the rise of atmospheric oxygen. Nature 427:117-120

Bente K, Nielsen H (1982) Experimental S isotope fractionation studies between coexisting bismuthinite $\left(\mathrm{Bi}_{2} \mathrm{~S}_{3}\right)$ and sulfur $\left(\mathrm{S}^{\circ}\right)$. Earth Planet Sci Lett 59:18-20

Berner RA (1985) Sulphate reduction, organic matter decomposition and pyrite formation. Phil Trans R Soc London A 315:25-38

Bethke PM, Rye RO, Stoffregen RE, Vikre PG (2005) Evolution of the magmatic-hydrothermal acid-sulfate system at Summitville, Colorado: integration of geological, stable-isotope, and fluid-inclusion evidence. Chem Geol 215:281-315

Bigeleisen J (1952) The effects of isotopic substitution on the rates of chemical reactions. J Phys Chem 56 823-828

Bigeleisen J, Mayer MG (1947) Calculation of equilibrium constants for isotopic exchange reactions. J Chem Phys 15:261-267

Bischoff JL, Seyfried WE (1978) Hydrothermal chemistry of seawater from $25^{\circ}$ to $350{ }^{\circ} \mathrm{C}$. Am J Sci 278 838-860

Bouška V, Pešek J (1999) Quality parameters of lignite of the North Bohemian Basin in the Czech Republic in comparison with world average lignite. Intl J Coal Geol 40:211-235

Buchanan DL, Nolan J, Suddaby P, Rouse JE, Viljoen MJ, Davenport JWJ (1981) The genesis of sulfide mineralization in a portion of the Potgietersrus Limb of the Bushveld Complex. Econ Geol 76:568-579

Burnham CW, Ohmoto H (1980) Late-stage process of felsic magmatism. Soc Mining Geol Japan Spec Issue 8:1-11

Canfield DE (2001) Biogeochemistry of sulfur isotopes. Rev Mineral Geochem 43:607-636

Canfield DE (2004) The evolution of the Earth surface sulfur reservoir. Am J Sci 304:839-861

Canfield DE, Teske A (1996) Late Proterozoic rise in atmospheric oxygen concentration inferred from phylogenetic and sulfur-isotope studies. Nature 382:127-132

Casadevall T, Ohmoto H (1977) Sunnyside mine, Eureka mining district, San Juan County, Colorado: geochemistry of gold and base metal ore deposition in a volcanic environment. Econ Geol 72:1285-1320

Chambers LA (1982) Sulfur isotope study of a modern intertidal environment, and the interpretation of ancient sulfides. Geochim Cosmochim Acta 46:721-728

Chambers LA, Trudinger PA (1979) Microbiological fractionation of stable sulfur isotopes: A review and critique. Geomicrobiol J 1:249-293 
Chaussidon M, Albarède F, Sheppard SMF (1987) Sulphur isotope heterogeneity in the mantle from ion microprobe measurements of sulphide inclusions in diamonds. Nature 330:242-244

Chaussidon M, Albarède F, Sheppard SMF (1989) Sulphur isotope variations in the mantle from ion microprobe analyses of micro-sulphide inclusions. Earth Planet Sci Lett 92:144-156

Chu X, Ohmoto H, Cole DR (2004) Kinetics of sulfur isotope exchange between aqueous sulfide and thiosulfate involving intra- and intermolecular reactions at hydrothermal conditions. Chem Geol 211:217-235

Claypool GE, Holser WT, Kaplan IR, Sakai H, Zak I (1980) The age curves of sulfur and oxygen isotopes in marine sulfate and their mutual interpretations. Chem Geol 28:199-260

Clayton DD, Ramadurai S (1977) On presolar meteoritic sulphides. Nature 265:427-428

Clayton RN (1986) High temperature effects in the early solar system. Rev Mineral 16:129-140

Coleman ML, Moore MP (1978) Direct reduction of sulfates to sulfur dioxide for isotopic analysis. Anal Chem 50:1594-1595

Crowe DE, Valley JW, Baker KL (1990) Micro-analysis of sulfur-isotope ratios and zonation by laser microprobe. Geochim Cosmochim Acta 54:2075-2092

Czamanske GK, Rye RO (1974) Experimentally determined sulfur isotope fractionations between sphalerite and galena in the temperature range $600^{\circ}$ to $275^{\circ} \mathrm{C}$. Econ Geol 69:17-25

Dai S, Ren D, Tang Y, Shao L, Li S (2002) Distribution, isotopic variation and origin of sulfur in coals in the Wuda coalfield, Inner Mongolia, China. Intl J Coal Geol 51:237-250

Eastoe CJ (1983) Sulfur isotope data and the nature of the hydrothermal systems at the Panguna and Frieda porphyry copper deposits, Papua New Guinea. Econ Geol 78:201-213

Eldridge CS, Compston W, Williams IS, Both RA, Walshe JL, Ohmoto H (1988) Sulfur isotope variability in sediment-hosted massive sulfide deposits as determined using the ion microprobe SHRIMP: I. an example from the Rammelsberg orebody. Econ Geol 83:443-449

Eldridge CS, Compston W, Williams IS, Harris JW, Bristow JW (1991) Isotope evidence for the involvement of recycled sediments in diamond formation. Nature 353:649-653

Eldridge CS, Compston W, Williams IS, Harris JW, Bristow JW, Kinny PD (1995) Applications of the SHRIMP I ion microprobe to the understanding of processes and timing of diamond formation. Econ Geol 90:271-280

Farquhar J, Bao H, Thiemens M (2000a) Atmospheric influence of Earth's earliest sulfur cycle. Science 289: 756-758

Farquhar J, Savarino J, Jackson TL, Thiemens MH (2000b) Evidence of atmospheric sulphur in the martian regolith from sulphur isotopes in meteorites. Nature 404:50-52

Farquhar J, Jackson TL, Thiemens MH (2000c) A ${ }^{33}$ S enrichment in ureilite meteorites: evidence for a nebular sulfur component. Geochim Cosmochim Acta 64:1819-1825

Farquhar J, Wing BA, McKeegan KD, Harris JW, Cartigny P, Thiemens MH (2002) Mass-independent sulfur of inclusions in diamond and sulfur recycling on early Earth. Science 298:2369-2372

Farquhar J, Wing B (2003) Multiple sulfur isotopes and the evolution of the atmosphere. Earth Planet Sci Lett 213:1-13

Field CW (1966) Sulfur isotopic method for discriminating between sulfates of hypogene and supergene origin. Econ Geol 61:1428-1435

Field CW, Gustafson LB (1976) Sulfur isotopes in the porphyry copper deposit at El Salvador, Chile. Econ Geol 71:1533-1548

Field CW, Zhang L, Dilles JH, Rye RO, Reed MH (2005) Sulfur and oxygen isotopic record in sulfate and sulfide minerals of early, deep, pre-Main Stage porphyry Cu-Mo and late Main Stage base-metal mineral deposits, Butte district, Montana. Chem Geol 215:61-93

Fifarek RH, Rye RO (2005) Stable-isotope geochemistry of the Pierina high-sulfidation Au-Ag deposit, Peru: influence of hydrodynamics on $\mathrm{SO}_{4}{ }^{2-}-\mathrm{H}_{2} \mathrm{~S}$ sulfur isotopic exchange in magmatic-steam and steam-heated environments. Chem Geol 215:253-279

Gamo T, Okamura K, Charlou JL, Urabe T, Auzende JM, Ishibashi J, Shitashima K, Chiba H (1997) Acidic and sulfate-rich hydrothermal fluids from Manus back-arc basin, Papua New Guinea. Geology 25:139-142

Gao X, Thiemens MH (1991) Systematic study of sulfur isotopic composition in iron meteorites and the occurrence of excess ${ }^{33} \mathrm{~S}$ and ${ }^{36} \mathrm{~S}$. Geochim Cosmochim Acta 55:2671-2679

Gao X, Thiemens MH (1993a) Isotopic composition and concentration of sulfur in carbonaceous chondrites. Geochim Cosmochim Acta 57:3159-3169

Gao X, Thiemens MH (1993b) Variations in the isotopic composition of sulfur in enstatite and ordinary chondrites. Geochim Cosmochim Acta 57:3171-3176

Gavelin S, Parwel A, Ryhage R (1960) Sulfur isotope fractionation in sulfide mineralization. Econ Geol 55: 510-530

Gemmell JB, Large RR (1992) Stringer system and alteration zones underlying the Hellyer volcanic-hosted massive sulfide deposit, Tasmania, Australia. Econ Geol 87:620-649

Giesemann A, Jäger H-J, Norman AL, Krouse HR, Brand WA (1994) On-line sulfur-isotope determination using an elemental analyzer coupled to a mass spectrometer. Anal Chem 66:2816-2819 
Goldhaber MB, Kaplan IR (1975) Controls and consequences of sulfate reduction rates in recent marine sediments. Soil Sci 119:42-55

Goodfellow WD (1987) Anoxic stratified oceans as a source of sulphur in sediment-hosted stratiform $\mathrm{Zn}-\mathrm{Pb}$ deposits (Selwyn Basin, Yukon, Canada). Chem Geol 65:359-382

Goodfellow WD, Jonasson IR (1984) Ocean stagnation and ventilation defined by $\delta^{34}$ S secular trends in pyrite and barite, Selwyn Basin, Yukon. Geology 12:583-586

Goodfellow WD, Peter JM (1996) Sulphur isotope composition of the Brunswick No. 12 massive sulphide deposit, Bathurst mining camp, New Brunswick: implications for ambient environment, sulphur source, and ore genesis. Can J Earth Sci 33:231-251

Greenwood JP, Riciputi LR, McSween HY Jr., Taylor LA (2000a) Modified sulfur isotopic compositions of sulfides in the nakhlites and Chassigny. Geochim Cosmochim Acta 64:1121-1131

Greenwood JP, Mojzsis SJ, Coath CD (2000b) Sulfur isotopic compositions of individual sulfides in Martian meteorites ALH84001 and Nakhla: implications for crust-regolith exchange on Mars. Earth Planet Sci Lett 184:23-35

Grinenko VA, Thode HG (1970) Sulfur isotope effects in volcanic gas mixtures. Can J Earth Sci 7:1402-1409

Grootenboer J, Schwarz HP (1969) Experimentally determined sulfur isotope fractionation between sulfide minerals. Earth Planet Sci Lett 7:162-166

Habicht KS, Canfield DE (2001) Isotope fractionation by sulfate-reducing natural populations and the isotopic composition of sulfide in marine sediments. Geology 29:555-558

Hackley KC, Anderson TF (1986) Sulfur isotopic variation in low-sulfur coals from the Rocky Mountain region. Geochim Cosmochim Acta 50:1703-1713

Haur A, Hladikova J, Smejkal V (1973) Procedure of direct conversion of sulfates into $\mathrm{SO}_{2}$ for mass spectrometric analysis of sulfur. Isotopenpraxis 18: 433-436

Hayes JM, Lambert IB, Strauss H (1992) The sulfur-isotopic record. In: The Proterozoic Biosphere. Schopf JW, C Klein C (eds) Cambridge Univ Press, p 129-132

Heald P, Foley NK, Hayba DO (1987) Comparative anatomy of volcanic-hosted epithermal deposits: acidsulfate and adularia-sericite types. Econ Geol 82:1-26

Hedenquist JW, Arribas A Jr, Reynolds TJ (1998) Evolution of an intrusion-centered hydrothermal system: FarSoutheast-Lepanto porphyry-epithermal Cu-Au deposits, Philippines. Econ Geol 93:373-404

Herzig PM, Hannington MD, Fouquet Y, von Stackelberg U, Petersen S (1993) Gold-rich polymetallic sulfides from the Lau back arc and implications for the geochemistry of gold in sea-floor hydrothermal systems of the southwest Pacific. Econ Geol 88:2182-2209

Herzig PM, Petersen S, Hannington MD (1998) Geochemistry and sulfur-isotopic composition of the TAG hydrothermal mound, Mid-Atlantic Ridge $26^{\circ} \mathrm{N}$. Proc ODP, Sci Results 158:47-70

Holland HD (1965) Some applications of thermochemical data to problems of ore deposits, II. Mineral assemblages and the composition of ore-forming fluids. Econ Geol 60:1101-1166

Holland HD (1978) The Chemistry of the Atmosphere and Oceans. J. Wiley and Sons

Holser WT, Kaplan IR, Sakai H, Zak I (1979) Isotope geochemistry of oxygen in the sedimentary sulfate cycle. Chem Geol 25:1-17

Holt BD, Engelkemeier AG (1970) Thermal decomposition of barium sulfate to sulfur dioxide for mass spectrometric analysis. Anal Chem 42:1451-1453

Hu G, Rumble D, Wang P-L (2003) An ultraviolet laser microprobe for the in situ analysis of multisulfur isotopes and its use in measuring Archean sulfur isotope mass-independent anomalies. Geochim Cosmochim Acta 67:3101-3118

Hubberten H-W (1980) Sulfur isotope fractionation in the Pb-S, Cu-S and Ag-S systems. Geochem J 14:177184

Huston DL (1999) Stable isotopes and their significance for understanding the genesis of volcanic-associated massive sulfide deposits: A review. In: Volcanic-Associated Massive Sulfide Deposits: Processes and Examples in Modern and Ancient Settings. Reviews in Economic Geology, Vol. 8. Barrie CT, Hannington MD (eds) Soc Econ Geol, p 157-179

Hulston JR, Thode HG (1965a) Variations in the $\mathrm{S}^{33}, \mathrm{~S}^{34}$, and $\mathrm{S}^{36}$ contents of meteorites and their relation to chemical and nuclear effects. J Geophys Res 70:3475-3484

Hulston JR, Thode HG (1965b) Cosmic-ray produced $\mathrm{S}^{33}$ and $\mathrm{S}^{36}$ in the metallic phase of iron meteorites. J Geophys Res 70:4435-4442

Igumnov SA, Grinenko VA, Poner NB (1977) Temperature dependence of the distribution coefficient of sulfur isotopes between $\mathrm{H}_{2} \mathrm{~S}$ and dissolved sulfates in the temperature range $260-400{ }^{\circ} \mathrm{C}$. Geokhimiya $7: 1085-$ 1087

Ishihara S, Sasaki A (1989) Sulfur isotopic ratios of the magnetite-series and ilmenite-series granitoids of the Sierra Nevada batholith - a reconnaissance study. Geology 17:788-791

Janecky DR, Shanks WC III (1988) Computational modeling of chemical and sulfur isotopic reaction processes in seafloor hydrothermal systems: chimneys, massive sulfides, and subjacent alteration zones. Can Mineral 26:805-825 
Jensen ML (1957) Sulfur isotopes and mineral paragenesis. Econ Geol 52:269-281

Jensen ML (1959) Sulfur isotopes and hydrothermal mineral deposits. Econ Geol 54:374-394

Jensen ML (1967) Sulfur isotopes and mineral genesis. In: Geochemistry of Hydrothermal Ore Deposits. Barnes HL (ed) Holt, Rinehart, and Winston, p 143-165

Johnson CM, Beard BL, Beukes NJ, Klein C, O'Leary JM (2003) Ancient geochemical cycling in the earth as inferred from $\mathrm{Fe}$ isotope studies of banded iron formations from the Transvaal Craton. Contrib Mineral Petrol 144:523-547

Jones HD, Kesler SE, Furman FC, Kyle JR (1996) Sulfur isotope geochemistry of southern Appalachian Mississippi Valley-type deposits. Econ Geol 91:355-367

Jørgensen BB, Isaksen MF, Jannasch HW (1992) Bacterial sulfate reduction above $100{ }^{\circ} \mathrm{C}$ in deep-sea hydrothermal vent sediments. Science 258:1756-1757

Juliani C, Rye RO, Nunes CMD, Snee LW, Corrêa Silva RH, Monteiro LVS, Bettencourt JS, Neumann R, Neto AA (2005) Paleoproterozoic high-sulfidation mineralization in the Tapajós gold province, Amazonian Craton, Brazil: geology, mineralogy, alunite argon age, and stable-isotope constraints. Chem Geol 215:95-125

Kaiser CJ, Kelly WC, Wagner RJ, Shanks WC III (1987) Geologic and geochemical controls on mineralization in the Southeast Missouri Barite district. Econ Geol 82:719-734

Kajiwara Y, Krouse HR (1971) Sulfur isotope partitioning in metallic sulfide systems. Can J Earth Sci 8:13971408

Kaplan IR, Hulston JR (1966) The isotopic abundance and content of sulfur in meteorites. Geochim Cosmochim Acta 30:479-496

Kelley KD, Leach DL, Johnson CA, Clark JL, Fayek M, Slack JF, Anderson VM, Ayuso RA, Ridley WI (2004) Textural, compositional, and sulfur isotope variations of sulfide minerals in the Red Dog Zn-Pb-Ag deposits, Brooks Range, Alaska: implications for ore formation. Econ Geol 99:1509-1532

Kesler SE (1996) Appalachian Mississippi Valley-type deposits: paleoaquifers and brine provinces. Soc Econ Geol Spec Pub 4:29-57

Kesler SE, Jones HD, Furman FC, Sassen R, Anderson WH, Kyle JR (1994) Role of crude oil in the genesis of Mississippi Valley-type deposits: Evidence from the Cincinnati Arch. Geology 22:609-612

Kiyosu Y (1973) Sulfur isotopic fractionation among sphalerite, galena and sulfide ions. Geochem J 7:191-199

Kiyosu Y (1980) Chemical reduction and sulfur-isotope effects of sulfate by organic matter under hydrothermal conditions. Chem Geol 30:47-56

Krouse HR, Coplen TB (1997) Reporting of relative sulfur isotope-ratio data. Pure Appl Chem 69:293-295

Krouse HR, Ueda A, Campbell FA (1990) Sulphur isotope abundances in coexisting sulphate and sulphide: Kinetic isotope effects versus exchange phenomena. In: Stable Isotopes and Fluid Processes in Mineralization. Herbert HK, Ho SE (eds) The Univ Western Australia, Univ Extension Pub 23:226-243

Kulp JL, Ault WU, Feely HW (1956) Sulfur isotope abundances in sulfide minerals. Econ Geol 51:139-149

Larson PB, Maher K, Ramos FC, Chang Z, Gaspar M, Meinert LD (2003) Copper isotope ratios in magmatic and hydrothermal ore-forming environments. Chem Geol 201:337-350

Leggett JK (1980) British Lower Paleozoic black shales and their palaeo-oceanographic significance. J Geol Soc London 137:139-156

Li C, Ripley EM, Naldrett AJ (2003) Compositional variations of olivine and sulfur isotopes in the Noril'sk and Talnakh intrusions, Siberia: implications for ore-forming processes in dynamic magma conduits. Econ Geol 98:69-86

Longinelli A, Craig H (1967) Oxygen-18 variations in sulfate ions in sea water and saline lakes. Science 156: 56-59

Luhr JF, Logan AV (2002) Sulfur isotope systematics of the 1982 El Chichón trachyandesite: an ion microprobe study. Geochim Cosmochim Acta 66:3303-3316

Lyons PC, Whelan JF, Dulong FT (1989) Marine origin of pyritic sulfur in the Lower Bakerstown coal bed, Castleman coal field, Maryland (U.S.A.). Intl J Coal Geol 12:329-348

Macnamara J, Thode HG (1950) Comparison of the isotopic constitution of terrestrial and meteoritic sulphur. Phys Rev 78:307-308

Maréchal CN, Télouk P, Albarède F (1999) Precise analysis of copper and zinc isotopic compositions by plasmasource mass spectrometry. Chem Geol 156:251-273

McGoldrick PJ, Large RR (1992) Geologic and geochemical controls on gold-rich stringer mineralization in the Que River deposit, Tasmania. Econ Geol 87:667-685

McKibben MA, Riciputi LR (1998) Sulfur isotopes by ion microprobe. In Applications of Microanalytical Techniques to Understanding Mineralizing Processes. Reviews in Economic Geology Vol. 7. McKibben MA, Shanks WC III, Ridley WI (eds) Soc Econ Geol, p 121-139

McSween HY Jr, Riciputi LR, Paterson BA (1997) Fractionated sulfur isotopes in sulfides of the Kaidun meteorite. Meteoritics Planet Sci 32:51-54

Misra KC, Gratz JF, Lu C (1996) Carbonate-hosted Mississippi Valley-type mineralization in the ElmwoodGordonsville deposits, Central Tennessee zinc district: A synthesis. Soc Econ Geol Spec Pub 4:58-73 
Mojzsis SJ, Coath CD, Greenwood JP, McKeegan KD, Harrison TM (2003) Mass-independent isotope effects in Archean (2.5 to $3.8 \mathrm{Ga}$ ) sedimentary sulfides determined by ion microprobe analysis. Geochim Cosmochim Acta 67:1635-1658

Monster J, Anders E, Thode HG (1965) ${ }^{34} \mathrm{~S} /{ }^{\beta 2} \mathrm{~S}$ ratios for the different forms of sulfur in the Orgueil meteorite and their mode of formation. Geochim Cosmochim Acta 29:773-779

Nakai N, Jensen ML (1964) The kinetic isotope effect in the bacterial reduction and oxidation of sulfur Geochim Cosmochim Acta 28:1893-1912

Nielsen H, Pilot J, Grinenko LN, Grinenko VA, Lein AY, Smith JW, Pankina RG (1991) Lithospheric sources of sulphur. In: Stable Isotopes in the Assessment of Natural and Anthropogenic Sulphur in the Environment. Krouse HR, Grinenko VA (eds) SCOPE 43, J Wiley and Sons, p 65-132

Nriagu JO, Ress CE, Mekhtiyeva VL, Lein AY, Fritz P, Drimmie RJ, Pankina RG, Robinson RW, Krouse HR (1991) Hydrosphere. In: Stable Isotopes in the Assessment of Natural and Anthropogenic Sulphur in the Environment. Krouse HR, Grinenko VA (eds) SCOPE 43, J Wiley and Sons, p 177-265

Ohmoto H (1972) Systematics of sulfur and carbon isotopes in hydrothermal ore deposits. Econ Geol 67:551578

Ohmoto H (1986) Stable isotope geochemistry of ore deposits. Rev Mineral 16:185-225

Ohmoto H, Goldhaber MB (1997) Sulfur and carbon isotopes. In: Geochemistry of Hydrothermal Ore Deposits. Barnes HL (ed) J Wiley and Sons, p 517-611

Ohmoto H, Lasaga AC (1982) Kinetics of reactions between aqueous sulfates and sulfides in hydrothermal systems. Geochim Cosmochim Acta 46:1727-1745

Ohmoto H, Rye RO (1979) Isotopes of sulfur and carbon. In: Geochemistry of Hydrothermal Ore Deposits Barnes HL (ed) J Wiley and Sons, p 509-567

O'Neil JR (1986) Theoretical and experimental aspects of isotopic fractionation. Rev Mineral 16:1-40

O'Neil JR, Clayton RN, Mayeda TK (1969) Oxygen isotope fractionation in divalent metal carbonates. J Phys Chem 51:5547-5558

Ono S, Eigenbrode JL, Pavlov AA, Kharecha P, Rumble D, III, Kasting JF, Freeman KH (2003) New insights into Archean sulfur cycle from mass-independent sulfur isotope records from Hamersley Basin, Australia. Earth Planet Sci 213;15-30

Orr WL (1974) Changes in sulfur content and isotopic ratios of sulfur during petroleum maturation-study of Big Horn Paleozoic oils. Am Assoc Petrol Geol Bull 58:2295-2318

Paterson BA, Riciputi LR, McSween HY Jr. (1997) A comparison of sulfur isotope ratio measurement using two ion microprobe techniques and application to analysis of troilite in ordinary chondrites. Geochim Cosmochim Acta 61:601-609

Pavlov AA, Kasting JF (2002) Mass-independent fractionation of sulfur isotopes in Archean sediments: strong evidence for an anoxic Archean atmosphere. Astrobiology 2:27-41

Peters B (1959) Cosmic-ray produced radioactive isotopes as tracers for studying large-scale atmospheric circulation. J Atmos Terr Physics 13:351-370

Postgate JR (1984) The Sulfate-Reducing Bacteria. 2nd Ed., Cambridge University Press

Price FT, Shieh YN (1979) The distribution and isotopic composition of sulfur in coals from the Illinois Basin. Econ Geol 74:1445-1461

Price FT, Shieh YN (1986) Correlation between the $\delta^{34} S$ of pyritic and organic sulfur in coal and oil shale. Chem Geol 58:333-337

Puchelt H, Sabels BR, Hoering TC (1971) Preparation of sulfur hexafluoride for isotope geochemical analysis. Geochim Cosmochim Acta 35:625-628

Rai VK, Jackson TL, Thiemens MH (2005) Photochemical mass-independent sulfur isotopes in achondritic meteorites. Science 309:1062-1065

Rees CE, Holt BD (1991) The isotopic analysis of sulphur and oxygen. In: Stable Isotopes in the Assessment of Natural and Anthropogenic Sulphur in the Environment. Krouse HR, Grinenko VA (eds) SCOPE 43, J Wiley and Sons, p 43-64

Rees CE, Thode HG (1977) A ${ }^{33}$ S anomaly in the Allende meteorite. Geochim Cosmochim Acta 41:1679-1682

Rees CE, Jenkins WJ, Monster J (1978) The sulphur isotope geochemistry of ocean water sulphate. Geochim Cosmochim Acta 42:377-382

Richardson CK, Rye RO, Wasserman MD (1988) The chemical and thermal evolution of the fluids in the Cave-in-Rock fluorspar district, Illinois: stable isotope systematics at the Deardorff mine. Econ Geol 83: 765-783

Ripley EM, Al-Jassar TJ (1987) Sulfur and oxygen isotope studies of melt-country rock interaction, Babbitt CuNi deposit, Duluth Complex, Minnesota. Econ Geol 82:87-107

Ripley EM, Li C (2003) Sulfur isotope exchange and metal enrichment in the formation of magmatic Cu-Ni(PGE) deposits. Econ Geol 98:635-641

Ripley EM, Park Y-R, Li C, Naldrett AJ (1999) Sulfur and oxygen isotope evidence of country rock contamination in the Voisey's Bay Ni-Cu-Co deposit, Labrador, Canada. Lithos 47:53-68 
Ripley EM, Li C, Shin D (2002) Paragneiss assimilation in the genesis of magmatic Ni-Cu-Co sulfide mineralization at Voisey's Bay, Labrador: $\delta^{34} \mathrm{~S}, \delta^{13} \mathrm{C}$, and Se/s evidence. Econ Geol 97:1307-1318

Ripley EM, Lightfoot PC, Li C, Elswick ER (2003) Sulfur isotopic studies of continental flood basalts in the Noril'sk region: implications for the association between lavas and ore-bearing intrusions. Geochim Cosmochim Acta 67:2805-2817

Robinson BW (1973) Sulfur isotope equilibrium during sulfur hydrolysis at high temperatures. Earth Planet Sci Lett 18:443-450

Rumble D (2005) A mineralogical and geochemical record of atmospheric photochemistry. Am Mineral 90: 918-930

Rumble D III, Hoering TC, Palin JM (1993) Preparation of $\mathrm{SF}_{6}$ for sulfur isotope analysis by laser heating sulfide minerals in the presence of $\mathrm{F}_{2}$ gas. Geochim Cosmochim Acta 57:4499-4512

Rye RO (1993) The evolution of magmatic fluids in the epithermal environment: the stable isotope perspective. Econ Geol 88:733-753

Rye RO (2005) A review of the stable-isotope geochemistry of sulfate minerals in selected igneous environments and related hydrothermal systems. Chem Geol 215:5-36

Rye RO, Luhr JF, Wasserman MD (1984) Sulfur and oxygen isotope systematics of the 1982 eruptions of El Chichón volcano, Chiapas, Mexico. J Volcanol Geotherm Res 23:109-123

Rye RO, Bethke PM, Wasserman MD (1992) The stable isotope geochemistry of acid sulfate alteration. Econ Geol 87:225-262

Sælen G, Raiswell R, Talbot MR, Skei JM, Bottrell SH (1993) Heavy sedimentary sulfur isotopes as indicators of super-anoxic bottom-water conditions. Geology 21:1091-1094

Sakai H (1957) Fractionation of sulfur isotopes in nature. Geochim Cosmochim Acta 12:150-169

Sakai H (1968) Isotopic properties of sulfur compounds in hydrothermal processes. Geochem J 2:29-49

Sakai H, Dickson FW (1978) Experimental determination of the rate and equilibrium fractionation factors of sulfur isotope exchange between sulfate and sulfide in slightly acid solutions at $300{ }^{\circ} \mathrm{C}$ and 1000 bars. Earth Planet Sci Lett 39:151-161

Sakai H, Takenaka T, Kishima N (1980) Experimental study of the rate and isotope effect in sulfate reduction by ferrous oxides and silicates under hydrothermal conditions. Proc Third Internat Symp Water-Rock Interact, Edmonton, Alberta, p 75-76

Sakai H, Des Marais DJ, Ueda A, Moore JG (1984) Concentrations and isotope ratios of carbon, nitrogen, and sulfur in ocean-floor basalts. Geochim Cosmochim Acta 48:2433-2442

Salomons W (1971) Isotope fractionation between galena and pyrite and between pyrite and elemental sulfur. Earth Planet Sci Lett 11:236-238

Sangster DF (1968) Relative sulphur isotope abundances of ancient seas and strata-bound sulphide deposits. Geol Assoc Canada Proc 19:79-91

Santosh M, Masuda H (1991) Reconnaissance oxygen and sulfur isotopic mapping of Pan-African alkali granites and syenites in the southern Indian Shield. Geochem J 25:173-185

Sasaki A, Krouse HR (1969) Sulfur isotopes and the Pine Point Lead-Zinc mineralization. Econ Geol 64:718730

Sasaki A, Ishihara S (1979) Sulfur isotopic composition of the magnetite-series and ilmenite-series granitoids in Japan. Contrib Mineral Petrol 68:107-115

Savarino J, Romero A, Cole-Dai J, Bekki S, Thiemens MH (2003) UV induced mass-independent sulfur isotope fractionation in stratospheric volcanic sulfate. Geophys Res Lett 30, doi:10.1029/2003GL018134

Schiller WR, von Gehlen K, Nielsen H (1969) Hydrothermal exchange and fractionation of sulfur isotopes in synthesized $\mathrm{ZnS}$ and PbS. Econ Geol 64:350-352

Schwarcz HP (1973) Sulfur isotope analyses of some Sudbury, Ontario, Ores. Can J Earth Sci 10:1444-1459

Seal RR II (2003) Stable-isotope geochemistry of mine waters and related solids. In: Environmental Aspects of Mine Wastes. Jambor JL, Blowes DW, Ritchie AIM (eds) Mineralogical Association of Canada Short Series 31:303-334

Seal RR II, Ayuso RA, Foley NK, Clark SHB (2001) Sulfur and lead isotope geochemistry of hypogene mineralization at the Barite Hill gold deposit, Carolina Slate Belt, southeastern United States: a window into and through regional metamorphism. Min Deposita 36:137-148

Seal RR II, Wandless GA (2003) Sulfur isotope evidence for sea-floor mineralizing processes at the Bald Mountain and Mount Chase massive sulfide deposits, northern Maine. Econ Geol Monogr 11:567-587

Seal RR II, Rye RO, Alpers CN (2000a) Stable isotope systematics of sulfate minerals. Rev Mineral Geochem 40:541-602

Seal RR II, Turner RJW, Leitch CHB (2000b) Reconnaissance sulphur, oxygen, and hydrogen isotope data for mineralization and alteration in the Sullivan-North Star corridor and vicinity, British Columbia, Chapter 24. In: The Geological Environment of the Sullivan Deposit, British Columbia. Lydon JW, Höy T, Slack JF, Knapp ME (eds) Geol Assoc Canada, Min Dep Div, Spec Pub 1:470-481 
Seyfried WE, Bischoff JL (1981) Experimental seawater-basalt interaction at $300{ }^{\circ} \mathrm{C}, 500$ bars, chemical exchange, secondary mineral formation and implications for the transport of heavy metals. Geochim Cosmochim Acta 45:135-149

Shanks WC III (2001) Stable isotopes in seafloor hydrothermal systems. Rev Mineralogy Geochem 43:469525

Shanks WC III, Bischoff JL, Rosenbauer RJ (1981) Seawater sulfate reduction and sulfur isotope fractionation in basaltic systems: interaction of seawater with fayalite and magnetite at $200-350{ }^{\circ} \mathrm{C}$. Geochim Cosmochim Acta 45:1977-1995

Shanks WC III, Woodruff LG, Jilson GA, Jennings DS, Modene JS, Ryan BD (1987) Sulfur and lead isotope studies of stratiform $\mathrm{Zn}-\mathrm{Pb}-\mathrm{Ag}$ deposits, Anvil Range, Yukon: basinal brine exhalation and anoxic bottomwater mixing. Econ Geol 82;600-634

Shanks WC III, Böhlke JK, Seal RR II (1995) Stable isotopes in mid-ocean ridge hydrothermal systems: interactions between fluids, minerals, and organisms. In: Seafloor Hydrothermal Systems: Physical, Chemical, Biological, and Geological Interactions. Humphris SE, Zierenberg RA, Mullineaux LS, Thomson RE (eds) Geophys Monogr 91:194-221

Shanks WC III, Crowe DE, Johnson C (1998) Sulfur isotope analyses using the laser microprobe. In: Applications of Microanalytical Techniques to Understanding Mineralizing Processes. Reviews in Economic Geology, Vol. 7. McKibben MA, Shanks WC III, Ridley WI (eds) Society of Economic Geologists, p 141-153

Shearer CK, Layne GD, Papike JJ, Spilde MN (1996) Sulfur isotopic systematics in alteration assemblages in martian meteorite Allan Hills 84001. Geochim Cosmochim Acta 60:2921-2926

Shelton KL, Rye DM (1982) Sulfur isotopic compositions of ores from Mines Gaspé, Quebec: an example of sulfate-sulfide isotopic disequilibria in ore-forming fluids with applications to other porphyry type deposits. Econ Geol 77:1688-1709

Shimoyama T, Yamazaki K, Iijima A (1990) Sulphur isotopic composition in the Paleogene coal of Japan. Intl J Coal Geol 15:191-217

Smith JW, Batts BD (1974) The distribution and isotopic composition of sulfur in coal. Geochim Cosmochim Acta 38:121-133

Smith JW, Gould KW, Rigby D (1982) The stable isotope geochemistry of Australian coals. Organic Geochem 3:111-131

Solomon M, Rafter TA, Jensen ML (1969) Isotope studies on the Rosebery, Mount Farrell and Mount Lyell ores, Tasmania. Min Deposita 4:172-199

Solomon M, Eastoe CJ, Walshe JL, Green GR (1988) Mineral deposits and sulfur isotope abundances in the Mount Read Volcanics between Que River and Mount Darwin, Tasmania. Econ Geol 83:1307-1328

Spiker EC, Pierce BS, Bates AL, Stanton RW (1994) Isotopic evidence for the source of sulfur in the Upper Freeport coal bed (west-central Pennsylvania, U.S.A.). Chem Geol 114:115-130

Strauss H (1997) The isotopic composition of sedimentary sulfur through time. Palaeogeogr Palaeoclimat Palaeoecol 132:97-118

Suvorova VA (1978) Sulfur isotopic distribution between Mo, W and Sb sulfides by experimental fractionation Doklady Akademii Nauk SSSR 243:485-488

Suvorova VA, Tenishev AS (1976) An experimental study of equilibrium distribution of sulfur isotopes between $\mathrm{Mo}, \mathrm{Pb}, \mathrm{Zn}$, and Sn sulfides. Geokhimiya 11:1739-1742

Szabo A, Tudge A, Macnamara J, Thode HG (1950) The distribution of $\mathrm{S}^{34}$ in nature and the sulfur cycle. Science 111:464-465

Szaran J (1996) Experimental investigation of sulphur isotopic fractionation between dissolved and gaseous $\mathrm{H}_{2}$ S. Chem Geol 127:223-228

Taylor BE, Beaudoin G (2000) Sulphur isotope stratigraphy of the Sullivan Pb-Zn-Ag deposit, B.C.: evidence for hydrothermal sulphur, and bacterial and thermochemical sulphate reduction, Chapter 37. In The geological environment of the Sullivan deposit, British Columbia. Lydon JW, Höy T, Slack JF, Knapp ME (eds) Geol Assoc Canada, Min Dep Div, Spec Pub 1:696-719

Taylor BE, Wheeler MC (1994) Sulfur- and oxygen-isotope geochemistry of acid mine drainage in the western United States. In: Environmental geochemistry of sulfide oxidation. Alpers CN, Blowes DW (eds) Amer Chem Soc Symp Ser 550:481-514

Thode HG, Rees CE (1971) Measurements of sulphur concentrations and the isotope $\operatorname{ratios}{ }^{33} \mathrm{~S} /{ }^{32} \mathrm{~S},{ }^{34} \mathrm{~S} /{ }^{32} \mathrm{~S}$ and ${ }^{36} \mathrm{~S} /{ }^{32} \mathrm{~S}$ in Apollo 12 samples. Earth Planet Sci Lett 12:434-438

Thode HG, Macnamara J, Collins CB (1949) Natural variations in the isotopic content of sulphur and their significance. Can J Res B27:361-373

Thode HG, Kleerekoper H, McElcheran D (1951) Isotope fractionation in the bacterial reduction of sulphate. Research, London 4:581-582

Thode HG, Monster J, Dunford HB (1961) Sulfur isotope geochemistry. Geochim Cosmochim Acta 25:159174

Thode HG, Dunford HB, Shima M (1962) Sulfur isotope abundances of the Sudbury district and their geologic significance. Econ Geol 57:565-578 
Thode HG, Cragg CB, Hulston JR, Rees CE (1971) Sulphur isotope exchange between sulphur dioxide and hydrogen sulphide. Geochim Cosmochim Acta 35:35-45

Torssander P (1989) Sulfur isotope ratios of Icelandic rocks. Contrib Mineral Petrol 102:18-23

Ueda A, Sakai H (1984) Sulfur isotope study of Quaternary volcanic rocks from the Japanese island arc. Geochim Cosmochim Acta 44:579-587

Urey HC (1947) The thermodynamic properties of isotopic substances. J Chem Soc 1947:562-581

Westgate LM, Anderson TF (1982) Extraction of various forms of sulfur from coal and shale for stable sulfur isotope analysis. Anal Chem 54:2136-2139

Whelan JF, Cobb, JC, Rye RO (1988) Stable isotope geochemistry of sphalerite and other mineral matter in coal beds of the Illinois and Forest City basins. Econ Geol 83:990-1007

Whelan JF, Rye RO, deLorraine W (1984) The Balmat-Edwards zinc-lead deposits - synsedimentary ore from Mississippi Valley-type fluids. Econ Geol 79: 239-265

Woodruff LG, Shanks WC III (1988) sulfur isotope study of chimney minerals and vent fluids from $21^{\circ} \mathrm{N}$, East Pacific Rise: hydrothermal sulfur sources and disequilibrium sulfate reduction. J Geophys Res 93: $4562-4572$

Zhu XK, O'Nions RK, Guo Y, Belshaw NS, Rickard D (2000) Determination of natural Cu-isotope variation by plasma-source mass spectrometry: implications for use as geochemical tracers. Chem Geol 163:139149

Zientek ML, Ripley EM (1990) Sulfur isotope studies of the Stillwater Complex and associated rocks, Montana. Eco Geol 85:376-391 
